\title{
Hidden champions: a review of the literature \& future research avenues
}

\author{
Julian Schenkenhofer ${ }^{1}$ iD
}

Received: 7 July 2021 / Accepted: 1 December 2021 / Published online: 20 January 2022

(C) The Author(s) 2022

\begin{abstract}
Substantial efforts have contributed to overcome the scarcity of research on hidden champions. Nevertheless, literature has yet missed to compile a comprehensive review. Drawing on the insights of 112 publications, four strands of literature could be distinguished to unravel the essence of hidden champions. Research on hidden champions studies their (1) internationalization strategies, (2) R\&D and innovation strategies, the (3) worldwide and regional geographic distribution of hidden champions and finally (4) other research that could not be assigned to one of the first three strands. A hand-collected sample of 1372 German hidden champions exemplifies the key insights from the reviewed research articles. Discussing the findings of the different literature strands aims at drawing a conclusion on their main results and analytical pitfalls to eventually unfold and motivate future research avenues.
\end{abstract}

Keywords Literature review $\cdot$ Hidden champions $\cdot$ Niche strategy $\cdot$ Mittelstand Family firms

JEL Classification D4 $\cdot$ L1 $\cdot$ L22 $\cdot$ O32

\section{Introduction}

Up until a few years ago, research on hidden champions was still considered as scarce (Witt 2015; Rammer and Spielkamp 2015; Schlepphorst et al. 2016). Considering the large number of publications on hidden champions within the last decade, this view needs to be adjusted. In recent years, a large number of publications has contributed to a detailed investigation of the phenomenon of hidden champions. So far, however, no literature review has summarized and classified the findings, drawn up interim results, and given direction for future research.

Julian Schenkenhofer

julian.schenkenhofer@wiwi.uni-augsburg.de

1 Faculty of Business and Economics, University of Augsburg, Universitaetsstr. 16, 86159 Augsburg, Germany 
This article reviews the literature on hidden champions and elaborates four central strands of research. While a first field explores their internationalization strategies, a second field investigates their R\&D and innovation behaviour. A third field studies the determinants of their worldwide and regional geographic distribution. Finally, a fourth field is presented to summarize studies that could not be categorized within the first three fields of research. Reviewing 112 publications on hidden champions and a hand-collected firm sample of 1372 German hidden champions aims at unraveling the essence of hidden champions.

The terms Mittelstand, family firms and hidden champions have often been used as synonyms (Pahnke and Welter 2019b). Figure 1 illustrates that all of these concepts describe various types of companies that can coincide in any constellation, but also can appear separately without overlap. Thus, this review also provides a relational assessment of the various manifestations. To highlight the nature of hidden champions, the research field of hidden champions needs to be placed in the context of related strands of literature. For the majority of cases, hidden champions are family businesses and belong to the Mittelstand (IFM 2020a), which is why the various concepts have been likened to one another. The data sample of German hidden champions reveals that $62.3 \%$ indeed are family owned, as Table 1 illustrates. What distinguishes them from other Mittelstand and family businesses is their niche strategy. This insight illustrates why they should be studied against the background of the niche characteristic to best determine their nature. The analysis shows that the niche strategy determines a few specific business strategies of hidden champions (regarding e.g., internationalization, $\mathrm{R} \& \mathrm{D}$ investments and innovation) that differ from most other Mittelstand and family firms.

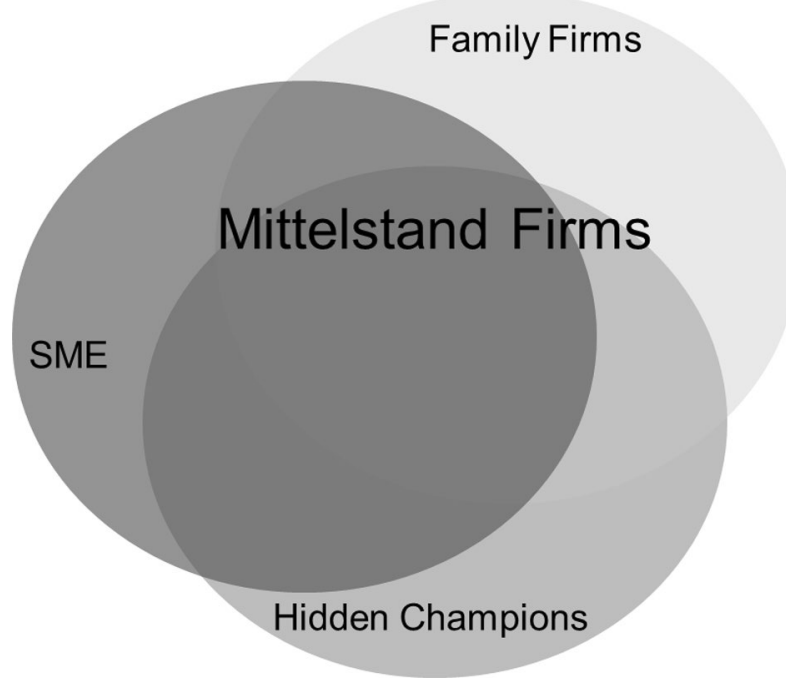

Fig. 1 The relationship between hidden champions, the Mittelstand, SMEs and family firms. Source: own depiction following Rosinus (2016) and IFM (2020a) 


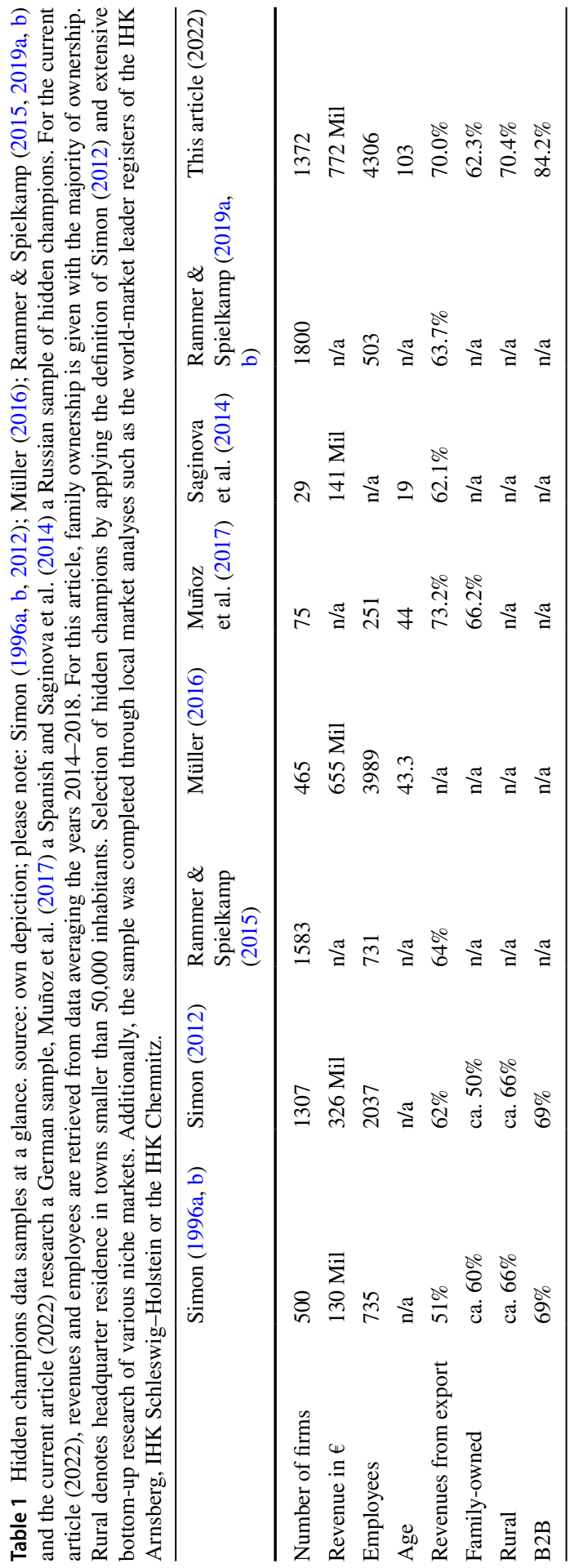


This study is based on the taxonomy of Cooper (1988) and other methodical literature on structuring literature reviews (Pautasso 2013; Torraco 2005). One lesson from this literature points out that the field of interest needs to be embedded within adjacent research. Therefore, the alignment to both other fields of research is relevant, since much of what we know from the Mittelstand and family business literature applies to hidden champions just alike. Most articles on hidden champions follow this approach and align their research to the Mittelstand literature (Venohr and Meyer 2007; Schlepphorst 2016) or the family business literature (Witt 2015; Lehmann et al. 2019; Audretsch et al. 2019). In addition to the (1) elaboration of four research streams within hidden champions' research and the (2) relational assessment of adjacent conceptions, this review contributes to Mittelstand research. Insights from previous research on the Mittelstand are collected to develop a (3) new typology of Mittelstand characteristics (Table 2). Another contribution of this article addresses the third part of Hermann Simon's (2009) definition of hidden champions: the low brand awareness of hidden champions and their products. So far, the brand awareness of hidden champions has never been quantified. As a main avenue of future research, this article elaborates (4) a first landmark to introduce an index that measures the niche brand awareness of hidden champions.

The remainder is structured as follows: Sect. 2 introduces the research design this literature review is subject to. Section 3 examines the field of research on hidden champions. First, Simon's model is illustrated, before one component of Porter's model of strategic competitive advantages is analysed in detail: the niche strategy. Section 3.3 then depicts the four main streams of research within the literature on hidden champions and summarizes key findings. Section 4 and 5 align the field of research on hidden champions to related fields of research (research on Mittelstand firms and family business research) and derives future research mandates that emerge when comparing the main insights of the fields. Section 6 concludes by discussing limitations and deriving further avenues for future research.

\section{Research method}

This article compiles a comprehensive literature review of research on hidden champions. Literature reviews, as a research design, are different from literature summaries in research articles, which can be found as subsections in the published literature or as contributions in the introduction of such articles. The difference manifests itself in the purpose of the literature review to provide a comprehensive overview of a broad spectrum of the research field. Literature reviews aim at pointing to topics that have been in the foreground of the analysis, aim at elaborating research outcomes that already have been achieved and aim at finding open questions and topics for further research. It is essential to draw a distinction to adjacent fields of research in order to identify similarities and differences. Thus, broader conclusions can be drawn from a comparison of different studies, which can help researchers to be sensitized for analytical and methodological pitfalls. The wider context of the field under consideration thus determines which findings either (1) can be taken over from other fields and thus be inherited in an integrative way or (2) reveal a difference 


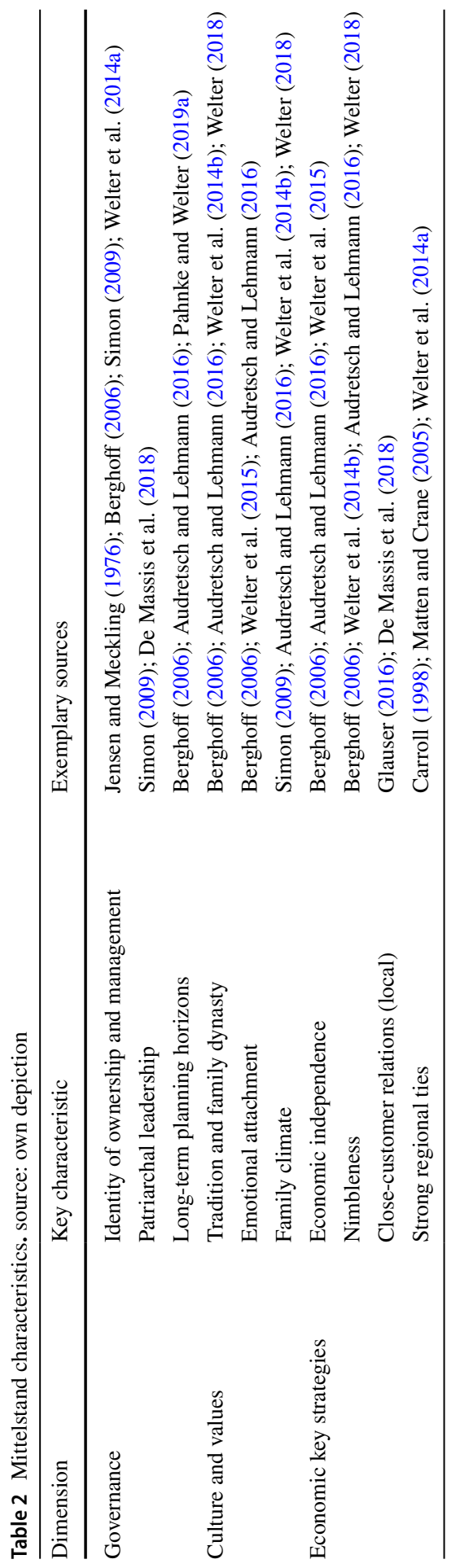


that separates the fields from each other (Webster and Watson 2002; Gabbott 2004; Torraco 2005; Randolph 2009; Pautasso 2013; Hart 2018)

The search for articles of this review includes a systematic, a backward and a forward literature search. The systematic search is a comprehensive search of literature from a bird's eye view, starting from relevant journals and work through to older years. The backward search, in turn, begins by determining one or more central sources and comparing the cited literature from these sources, thus working its way backwards through the years. The advantage here is that even for large strands of literature, such as the literature on family firms, essential and highly relevant literature is quickly identified. The forward literature search, in turn, also starts with key articles, but searches for the literature that cited a key article. In this way, the current, more recent literature is taken into account.

Following Cooper's taxonomy (1988), literature reviews can be classified by their focus, goal, perspective, coverage, organization, and audience. The research design thus structures itself through these characteristics, which in turn is determined by the nature of previous research within the field. Based on this taxonomy, this review focuses on research outcomes and theories of the respective strands of literature to explain the concepts and theoretical foundations of hidden champions. The second aim of this literature review is to identify those factors of hidden champions that distinguish them from other Mittelstand family firms. With regard to the coverage of this literature review, I compile an exhaustive review of research revolving around hidden champions. The number of 112 studies is a still manageable size, which allowed me to comprehensively consider every major publication within the field since the seminal works of Hermann Simon. All the scholarly articles and textbooks were retrieved from major academic databases. This literature review is organized in a conceptual and theory-based format, to derive factors that explain the characteristics and behaviour of hidden champions. The same applies to both the section on Mittelstand research and research on family businesses.

\section{Research on hidden champions}

While some years ago, authors still referred to research on hidden champions as scarce (Witt 2015; Rammer and Spielkamp 2015; Schlepphorst et al. 2016), this is no longer true today. This review summarizes the previous research on hidden champions and divides the field into four subcategories. Table 3 summarizes 112 publications on hidden champions.

Hermann Simon laid the foundation of hidden champions research in the 1990s with a series of articles (1990, 1992, 1996a) and his 1996 book Hidden champions: Lessons from 500 of the world's best unknown companies (1996b). Simon examines the export success of Germany beyond large corporations and concentrated his analysis on small and medium sized world-market leaders, that he termed hidden champions. In his basic model (three circles and nine lessons), he explains the essential characteristics of the strategy of hidden champions basing his analyses on a data sample of 500 German hidden champions. He continuously expanded this sample in further publications and adjusted the 


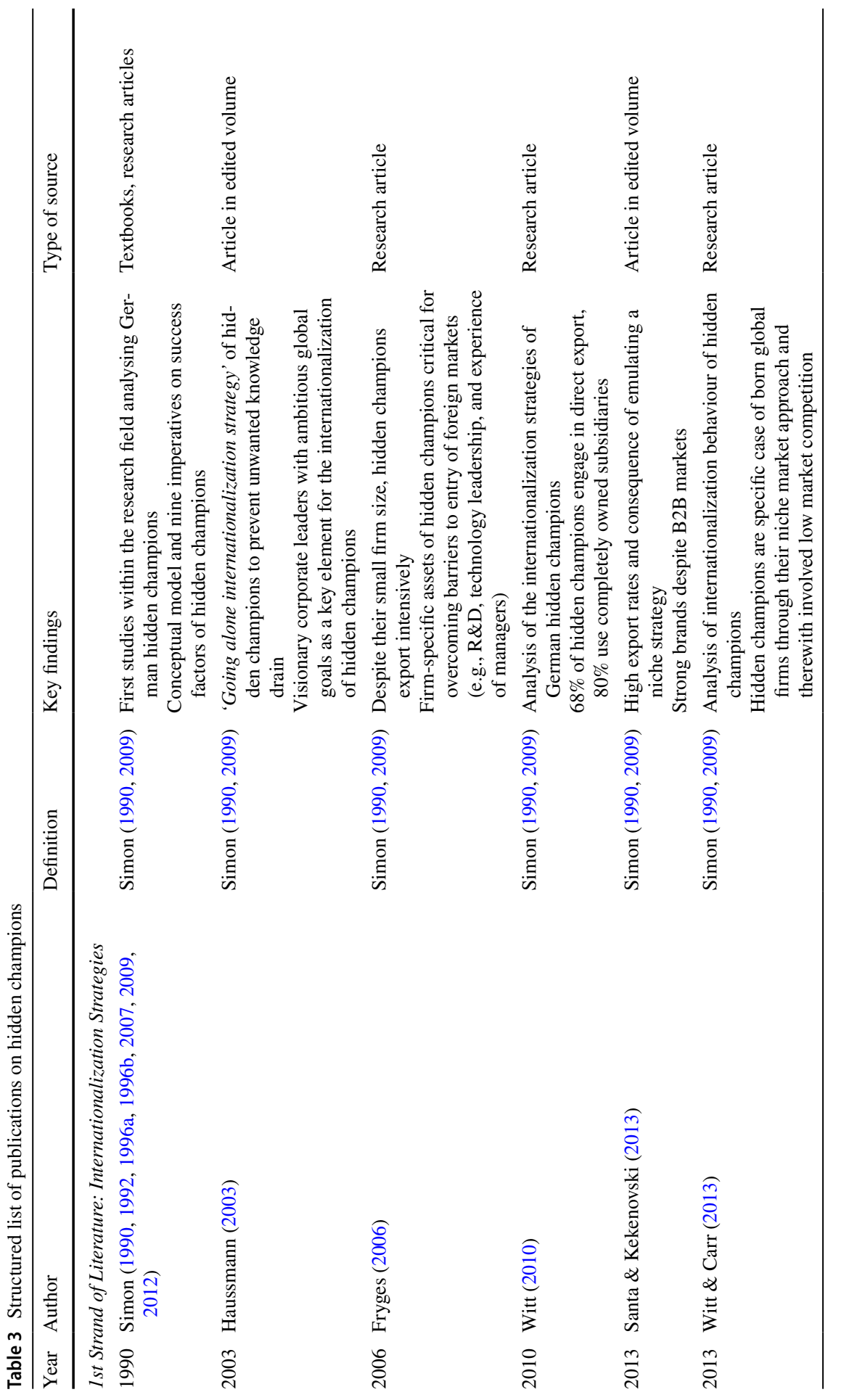




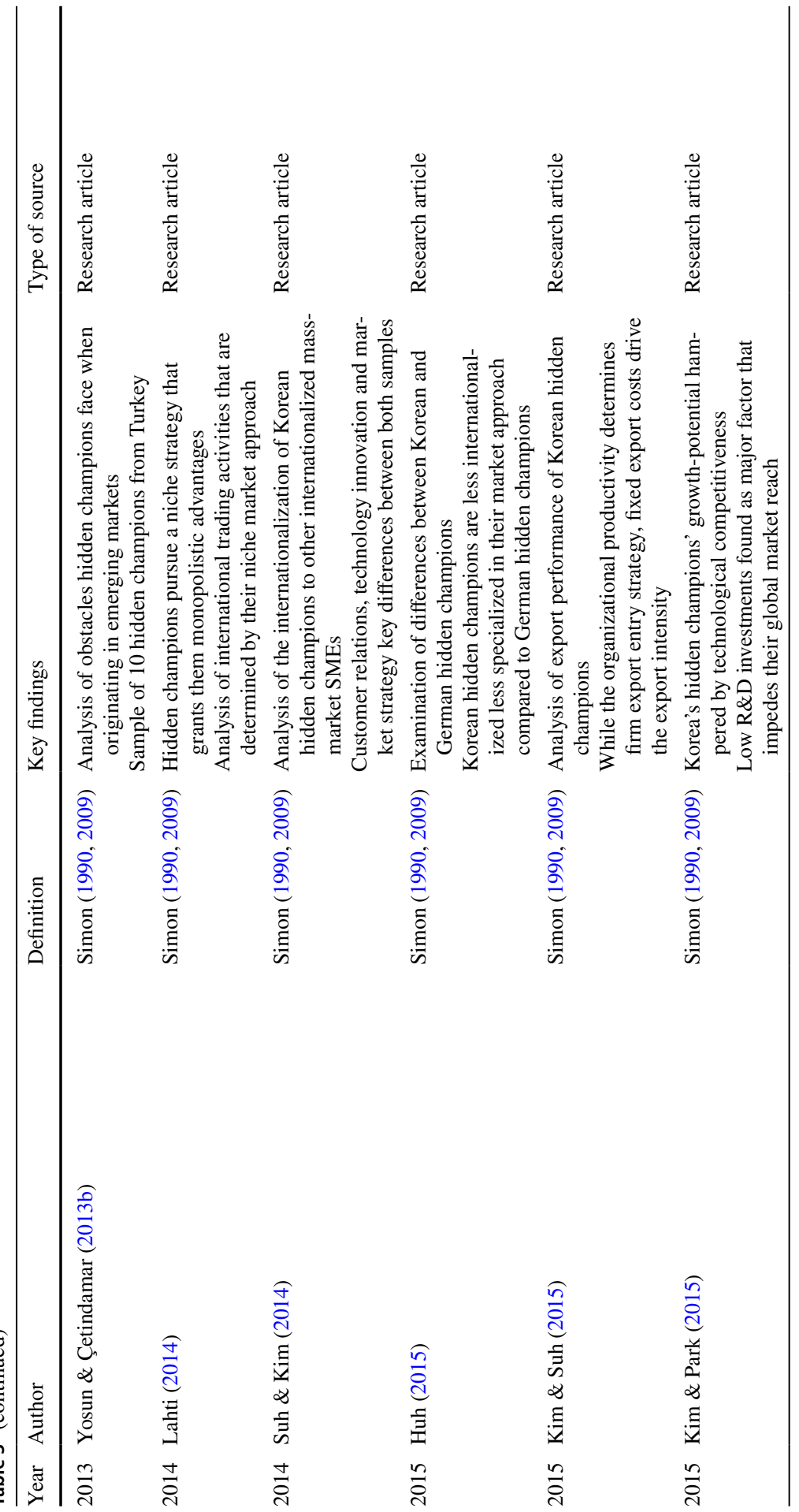




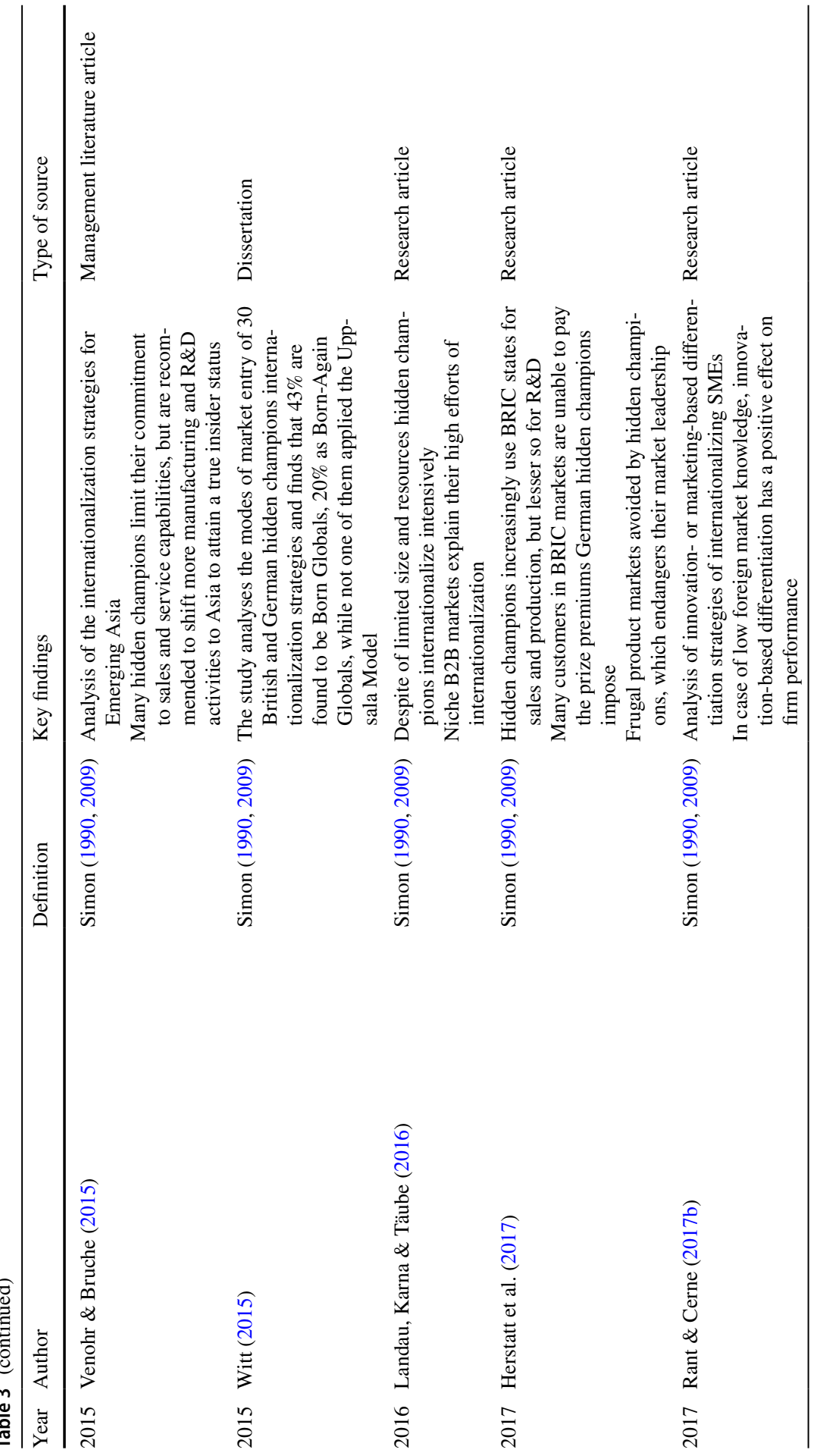




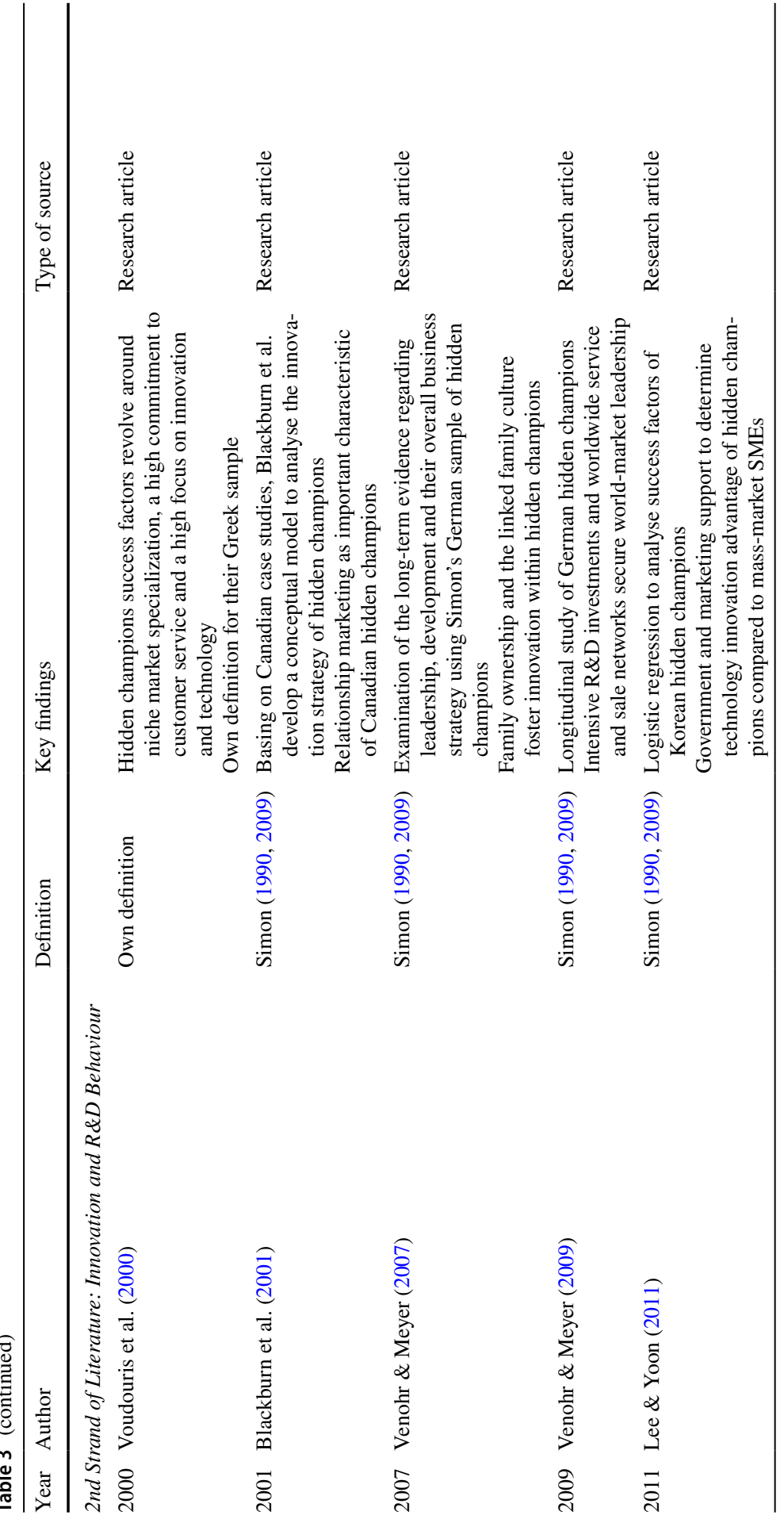




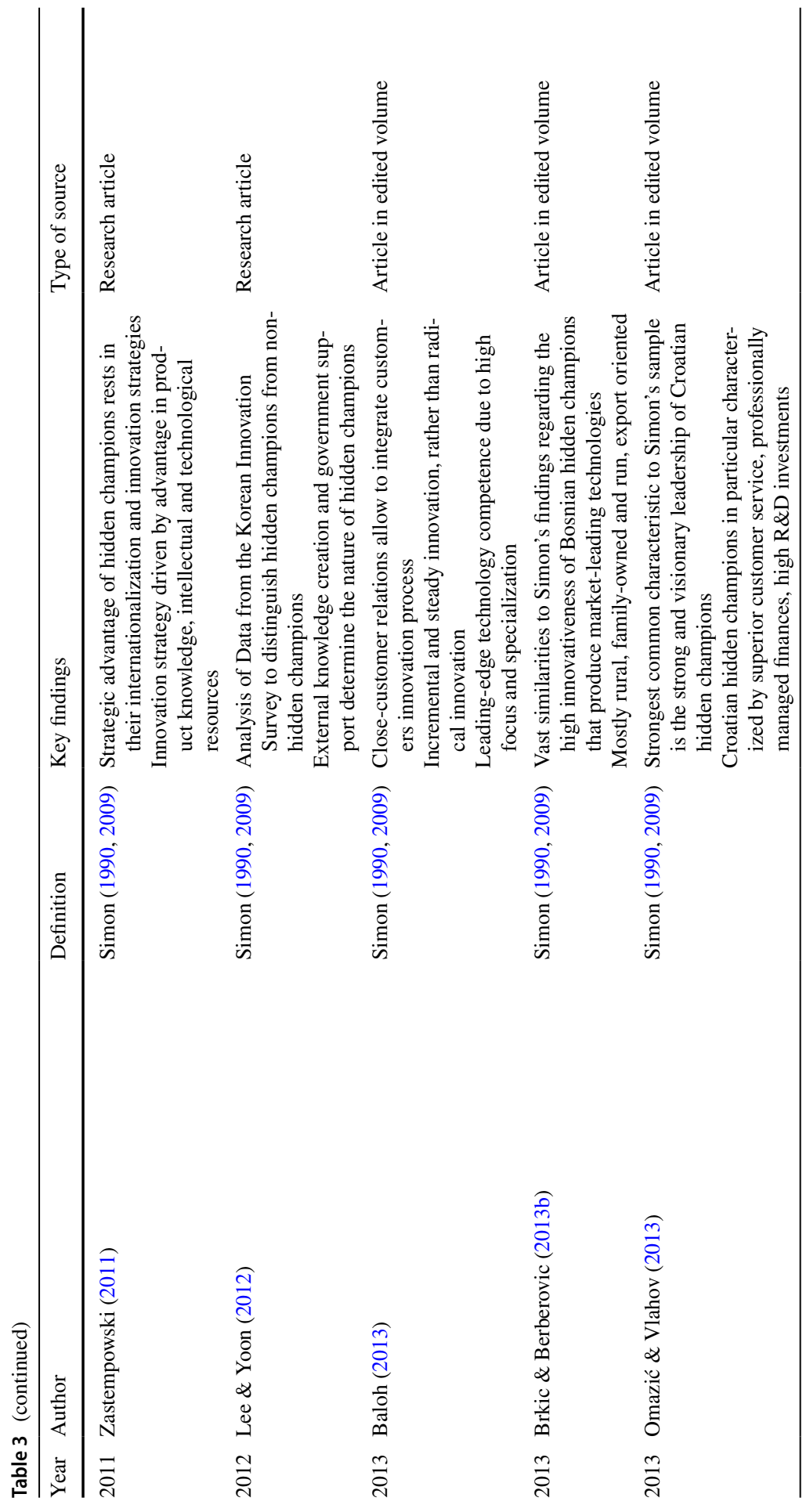




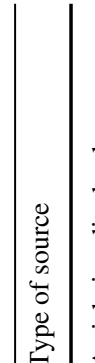

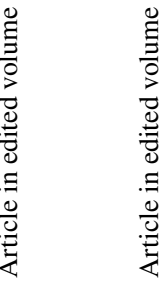

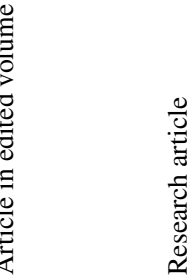

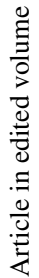



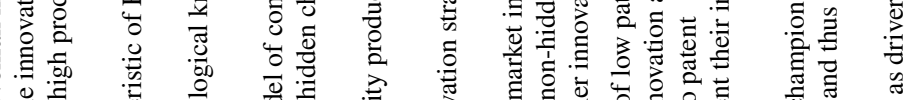

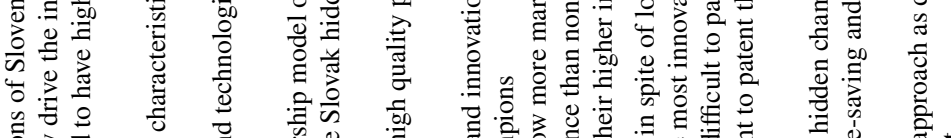

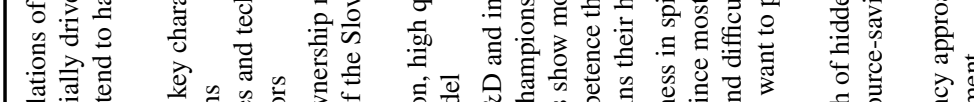

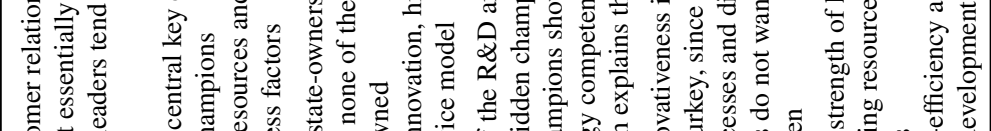

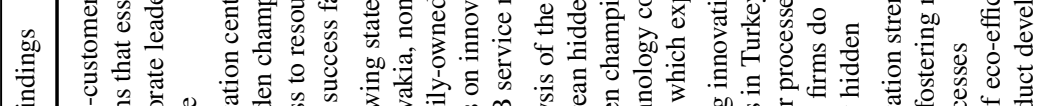

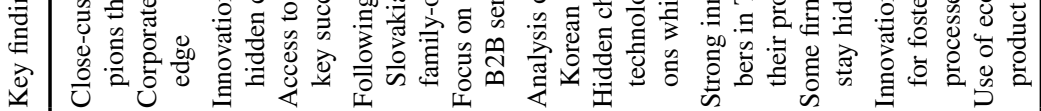

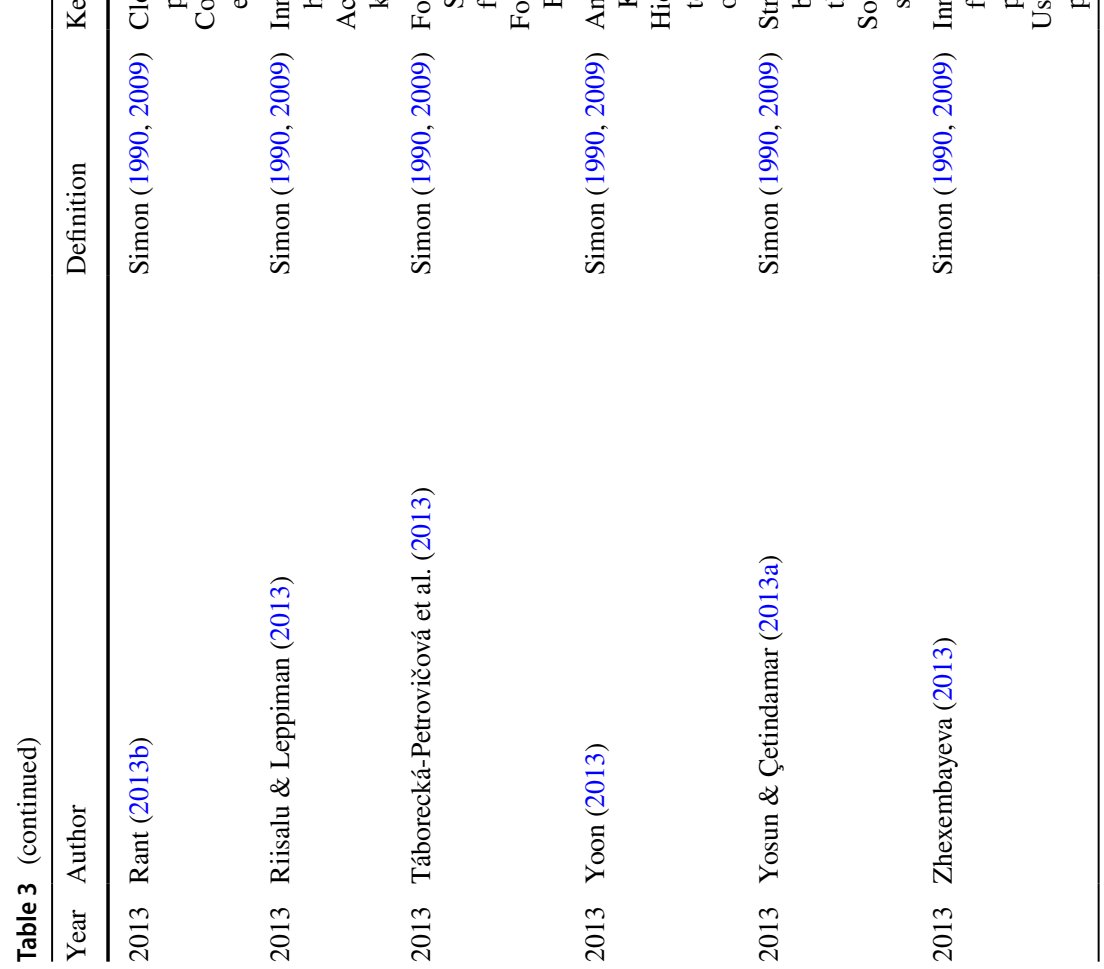




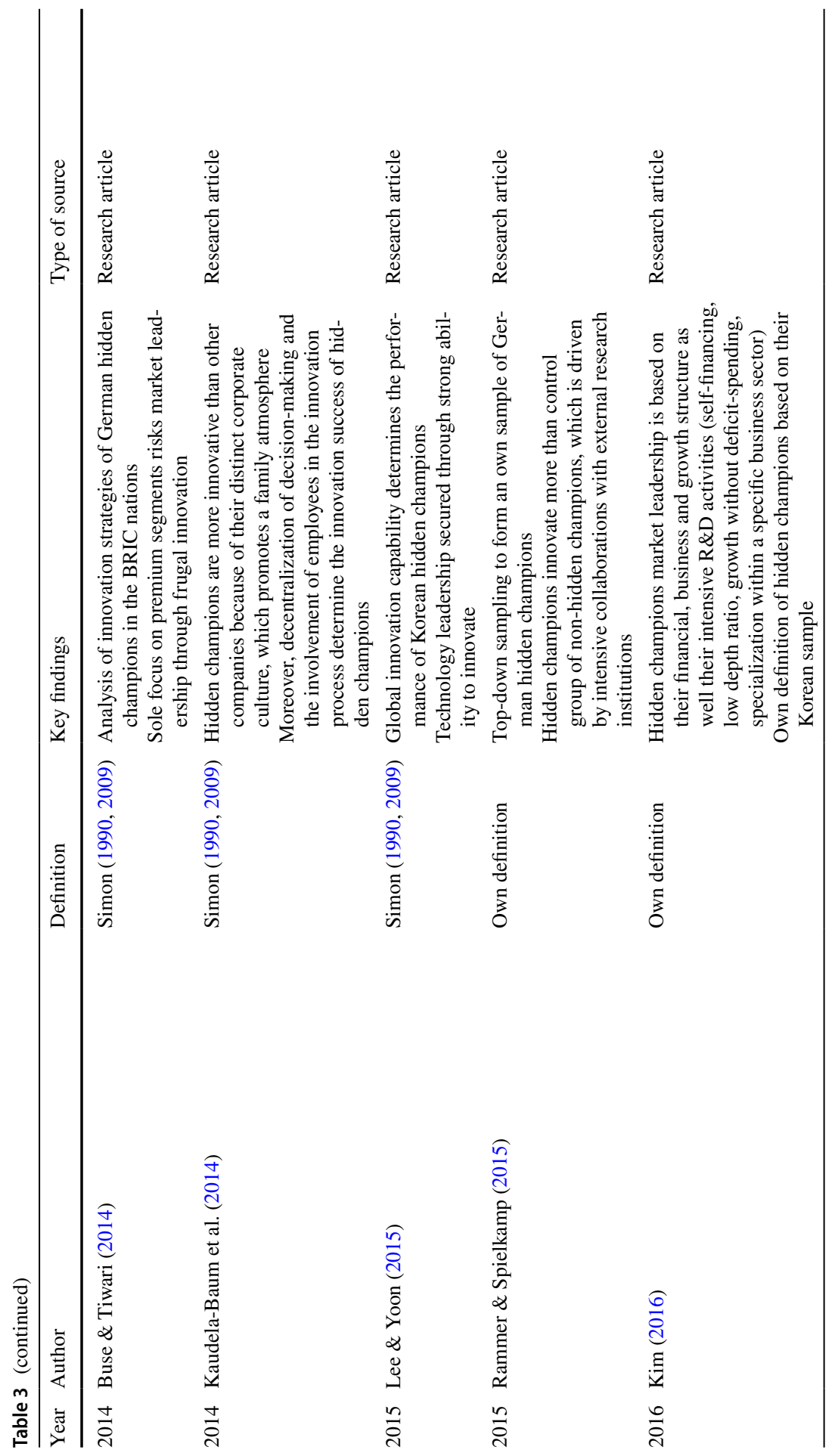




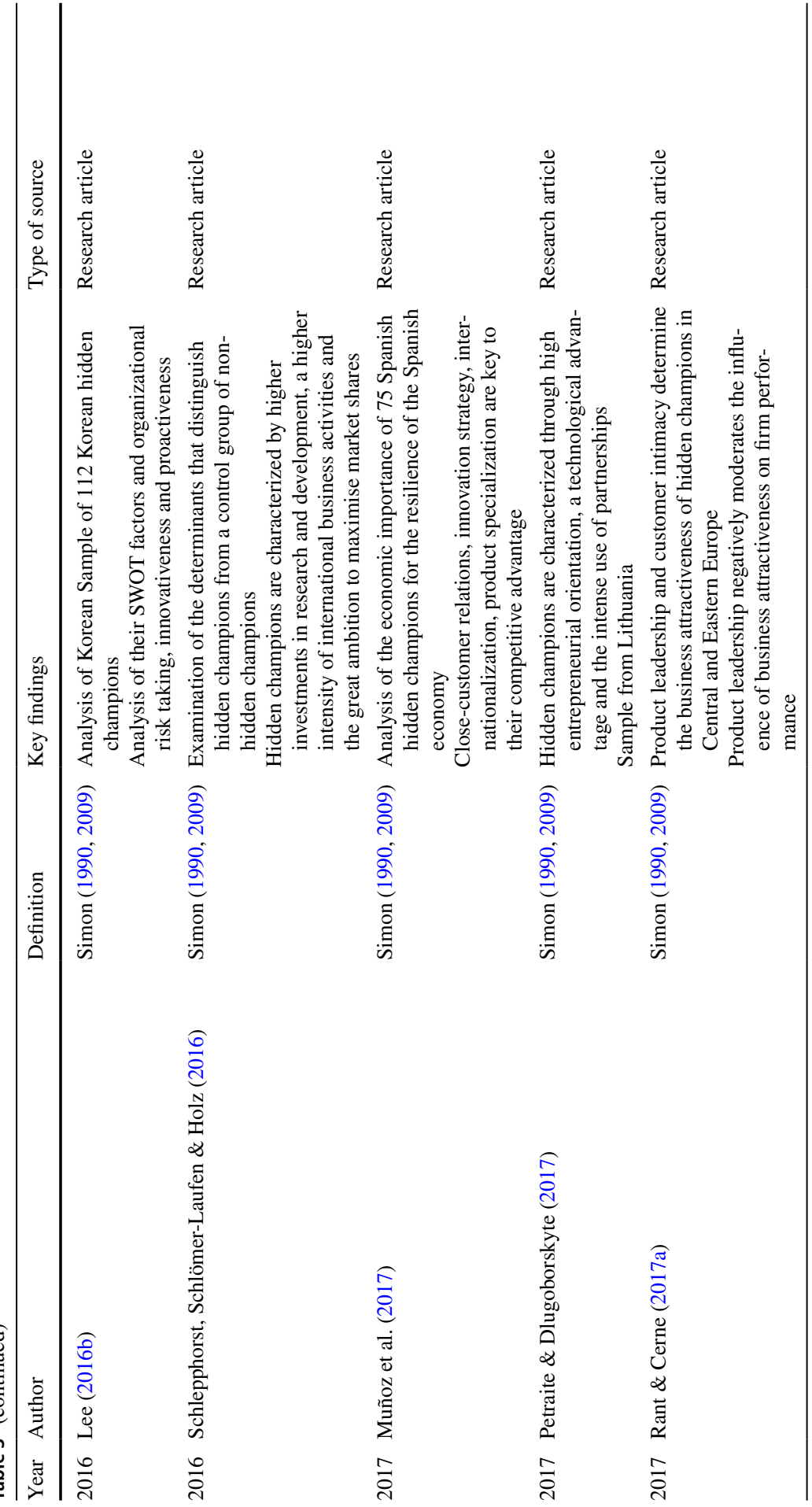




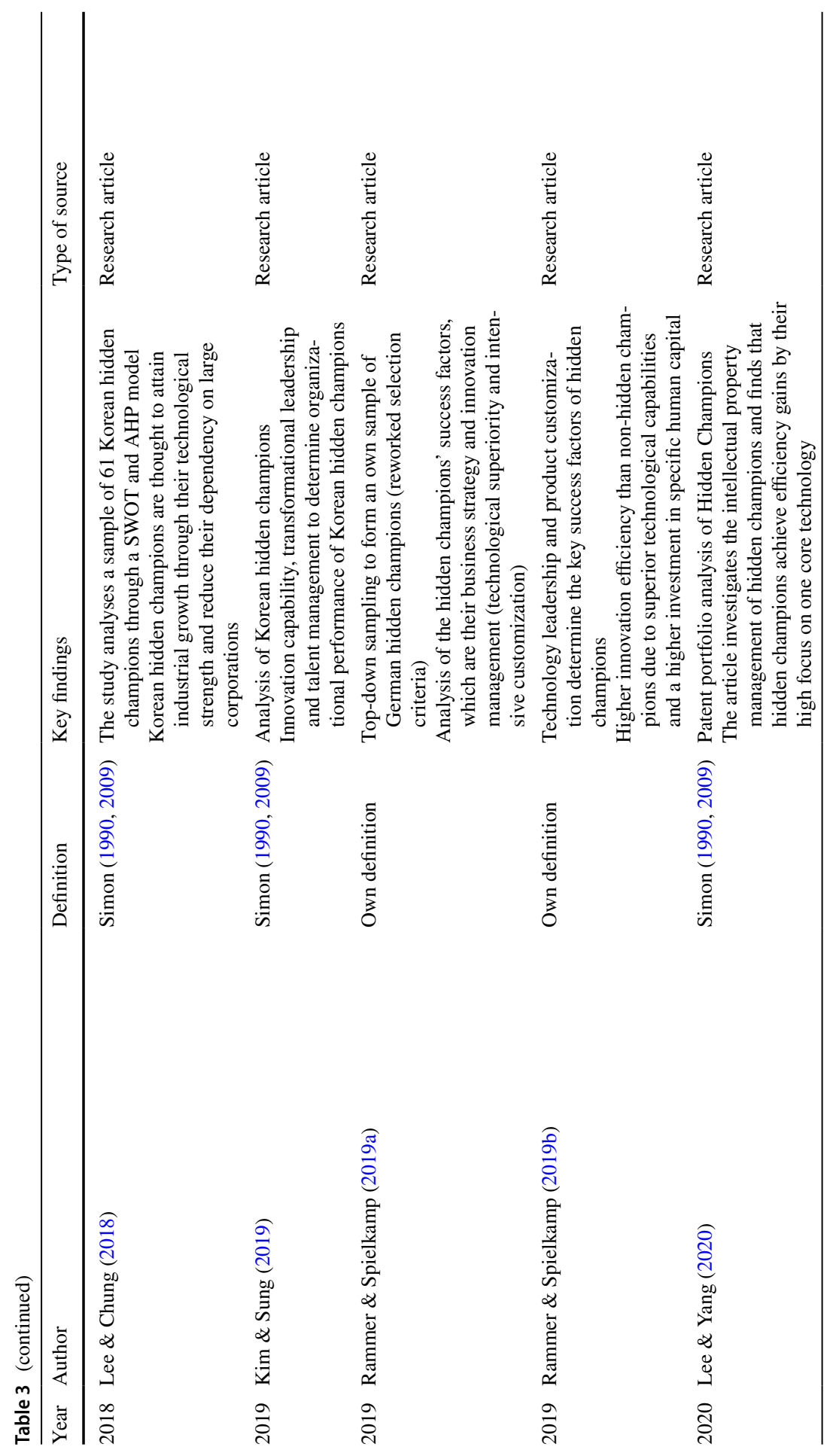




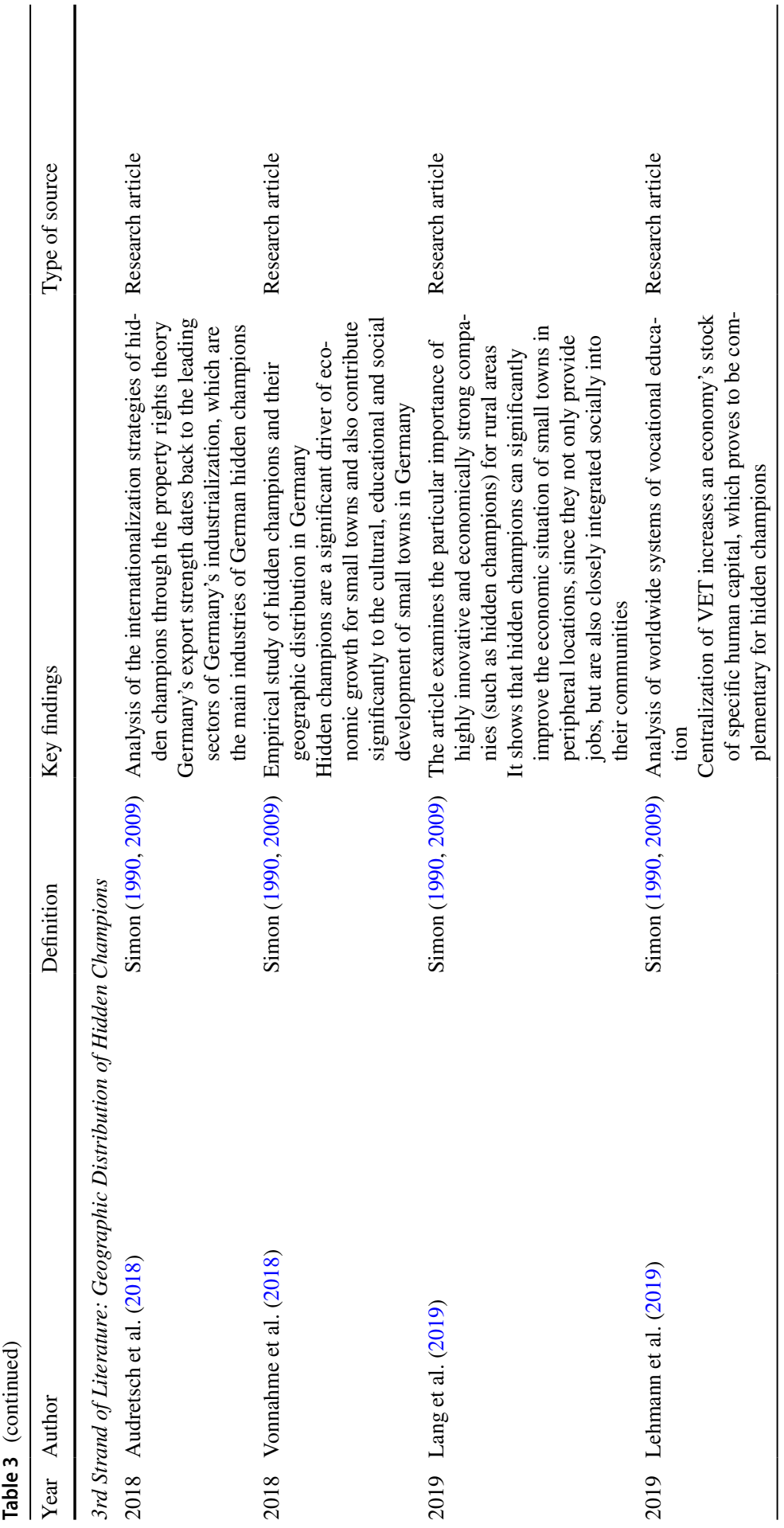




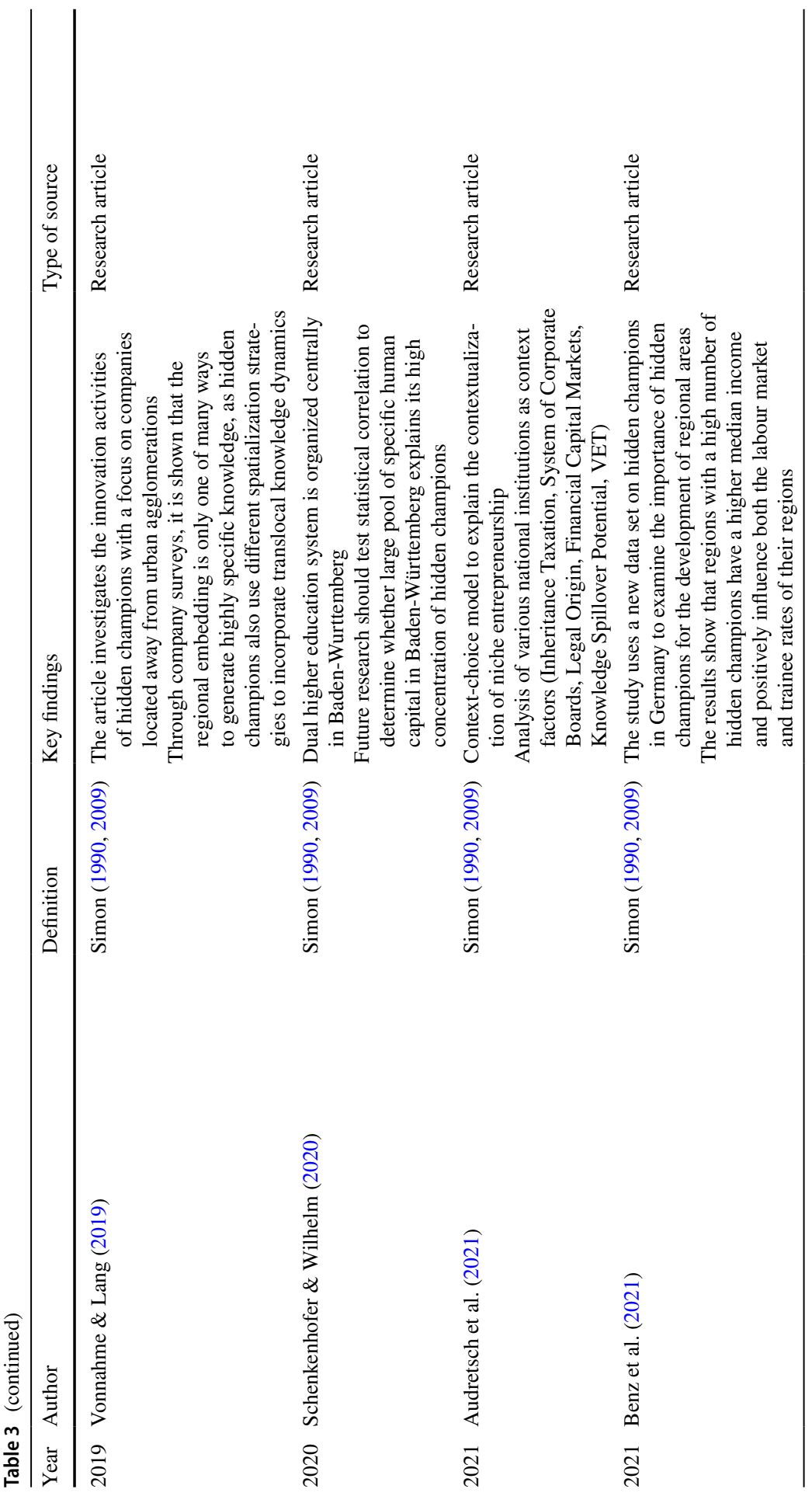




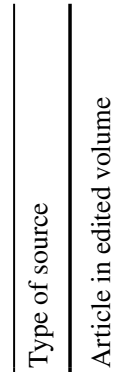

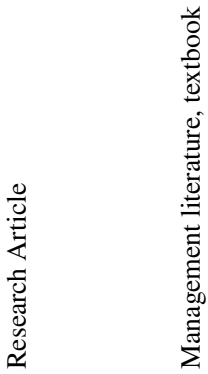

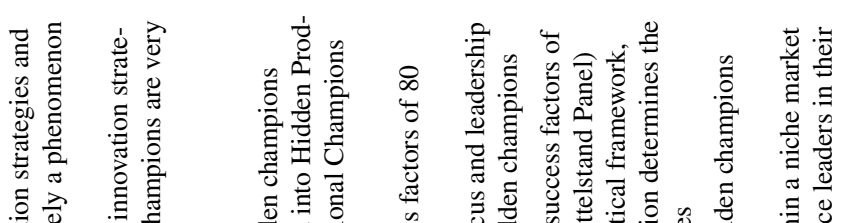

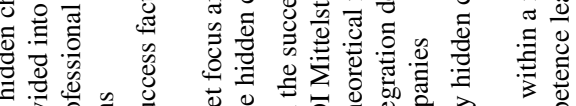

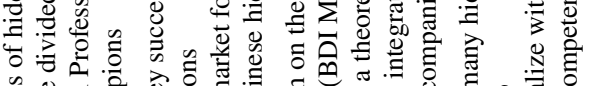

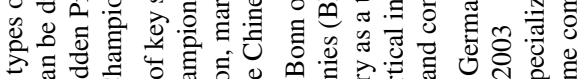

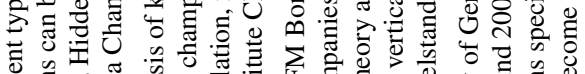

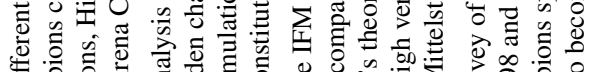



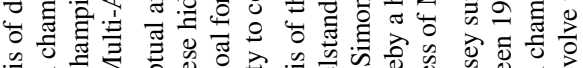

ठิ

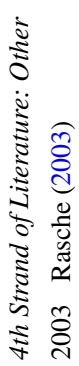

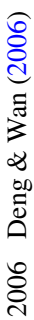

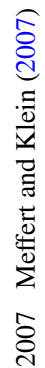




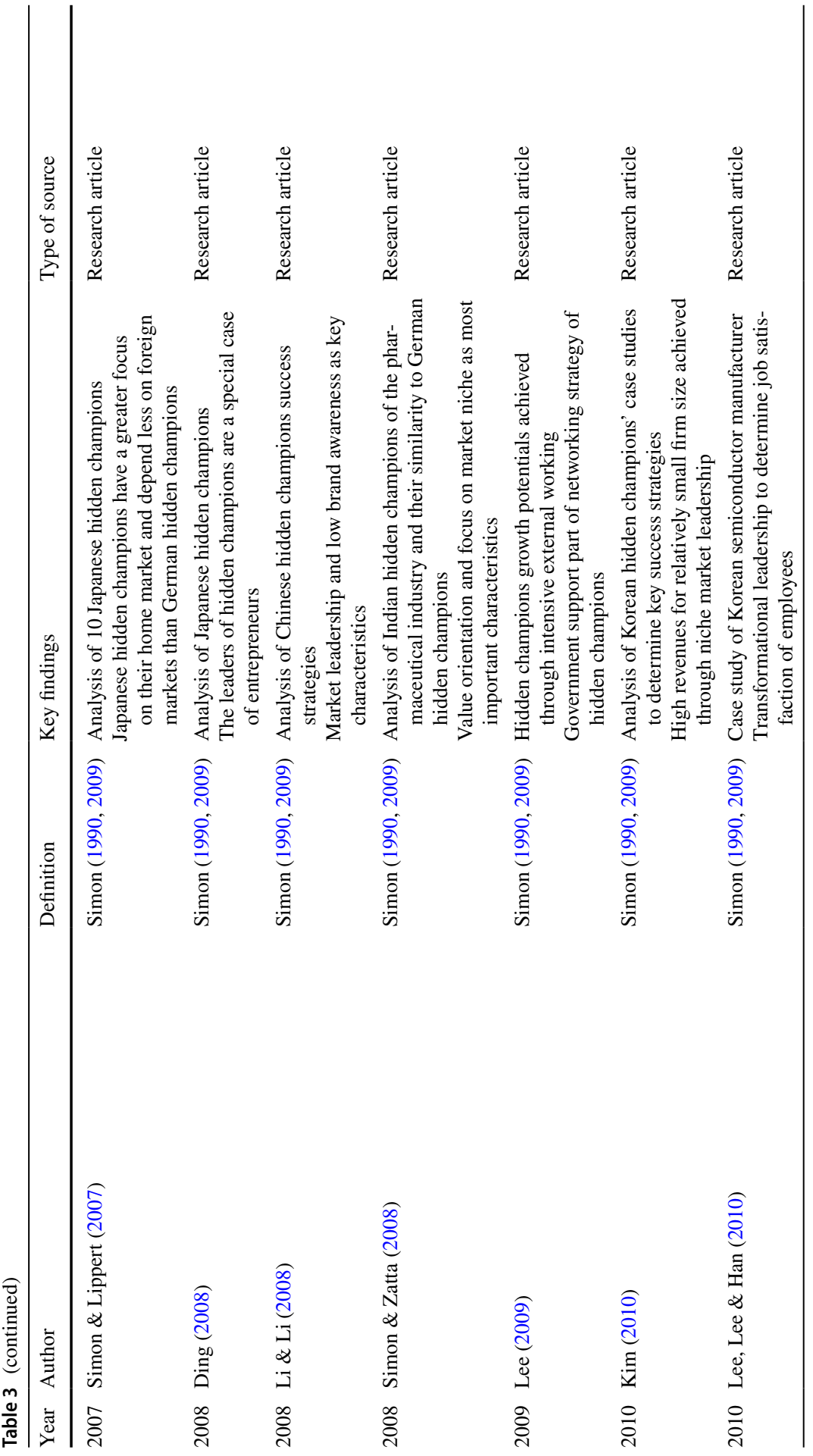




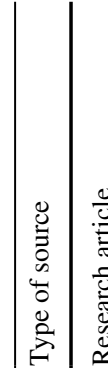

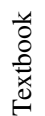

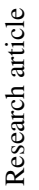

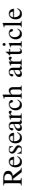

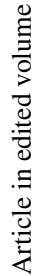

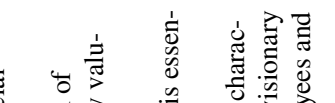

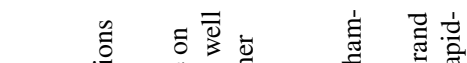

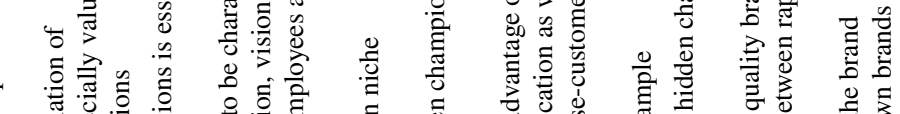

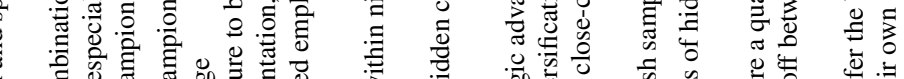

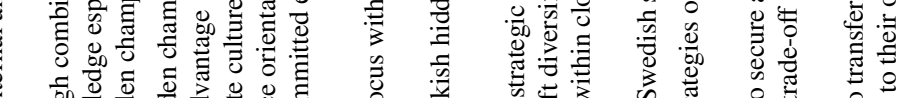
क0

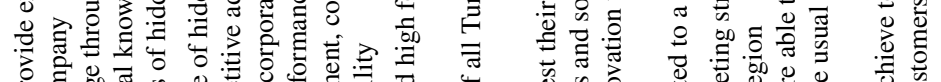

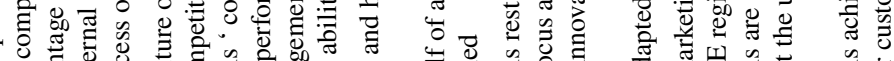

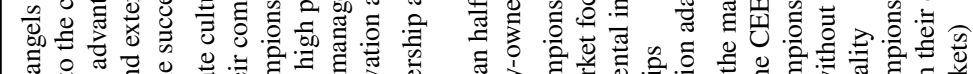



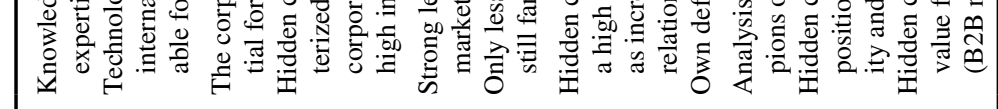

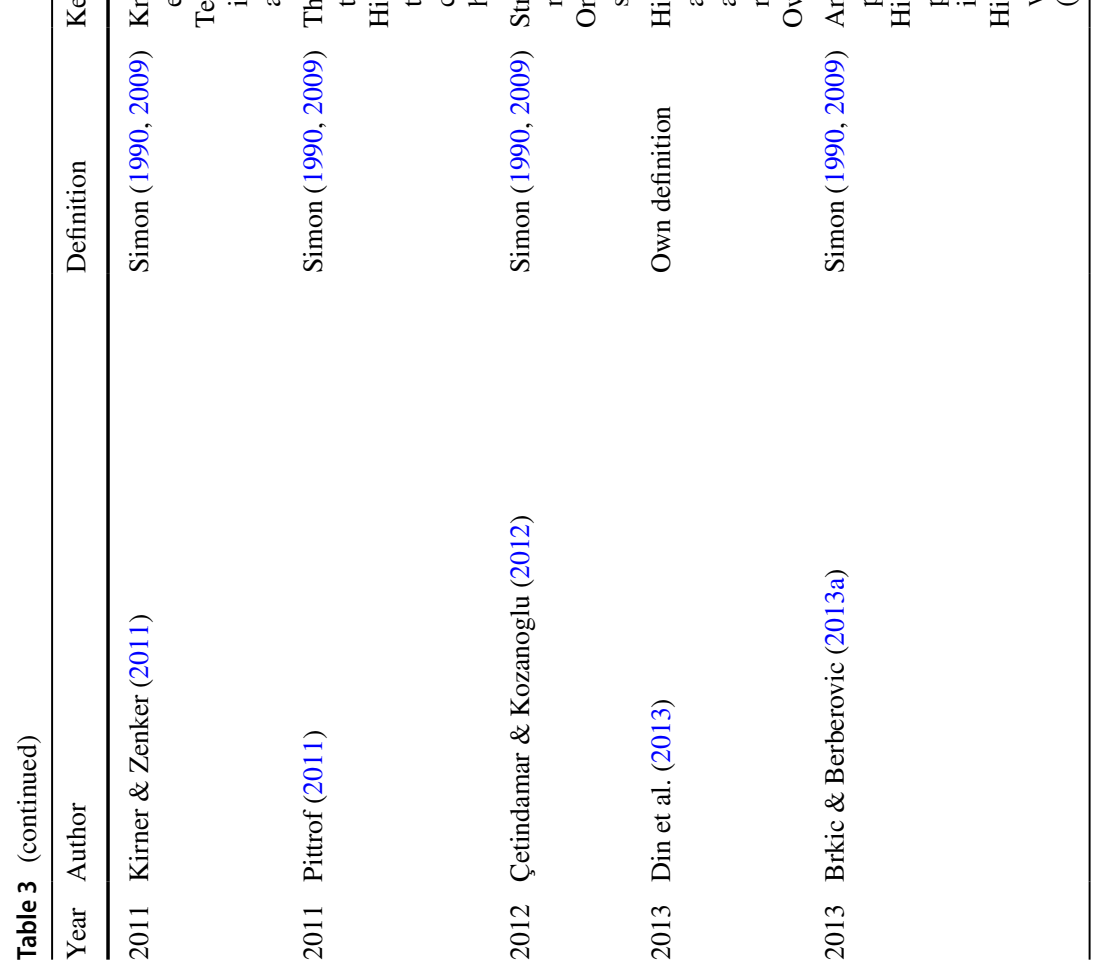




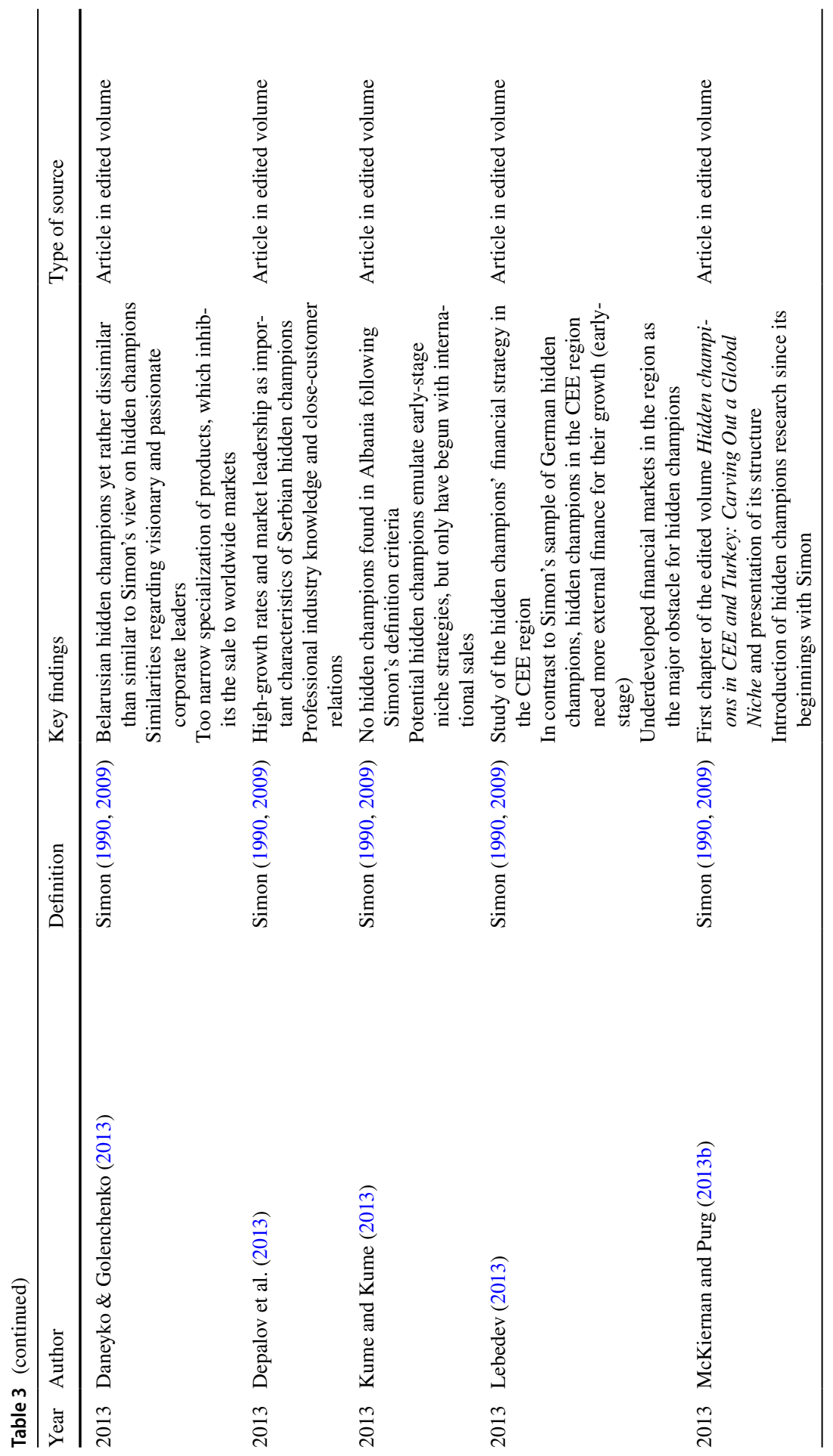




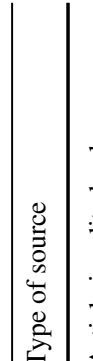

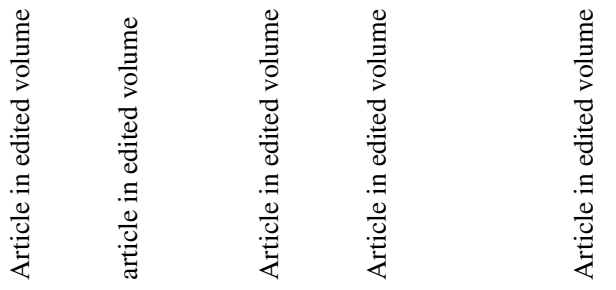

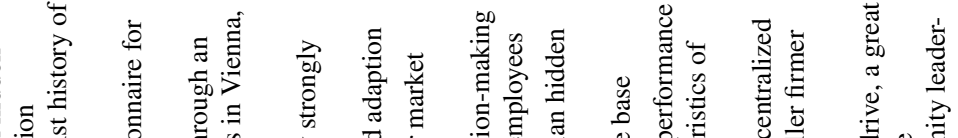

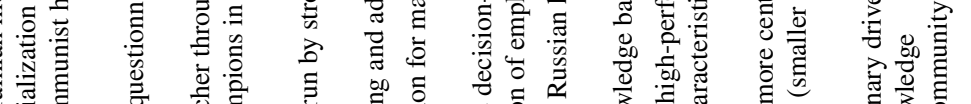

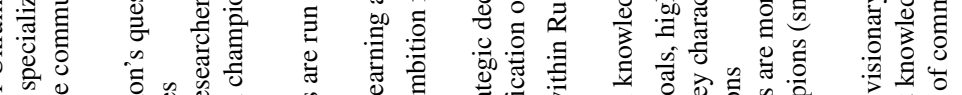

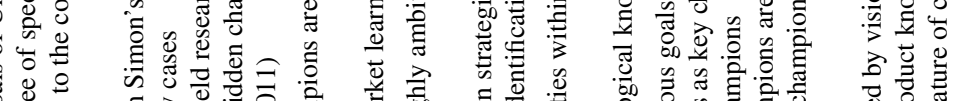

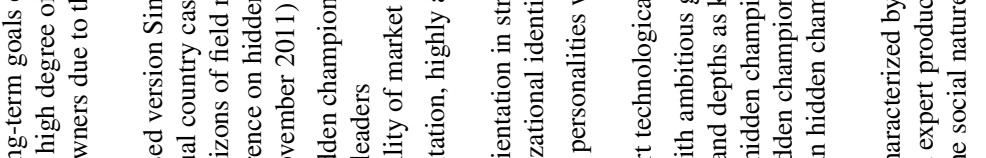

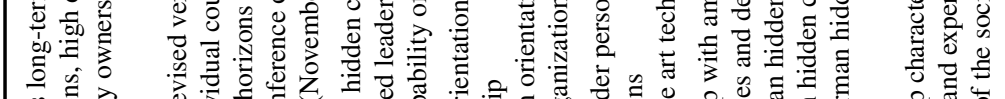

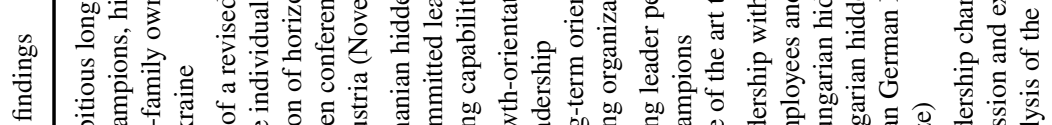

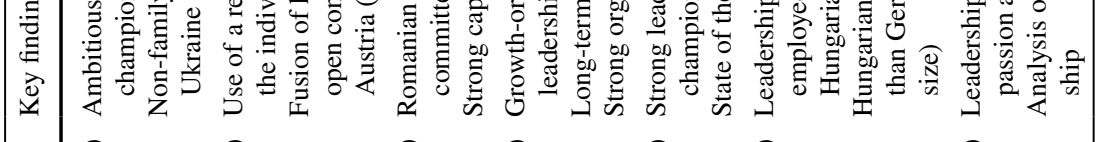

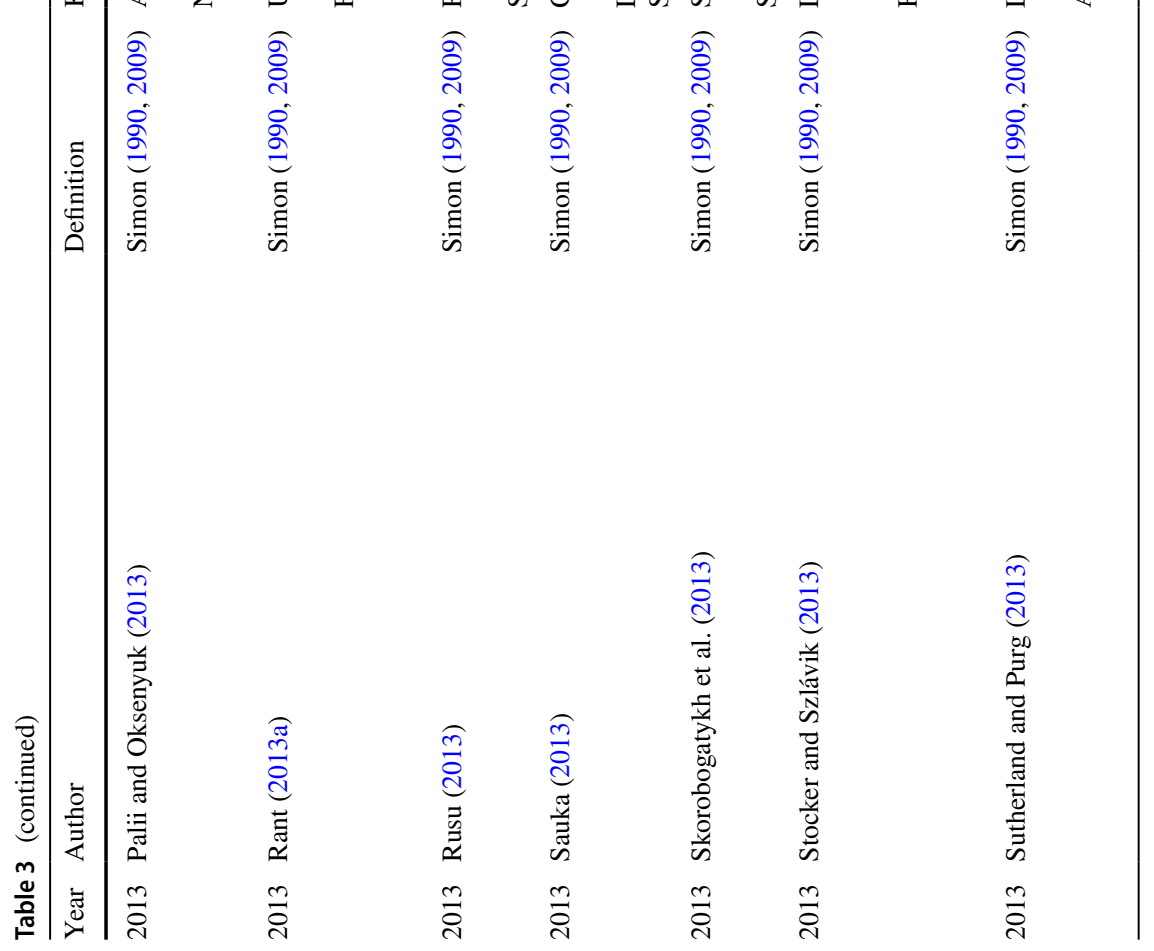




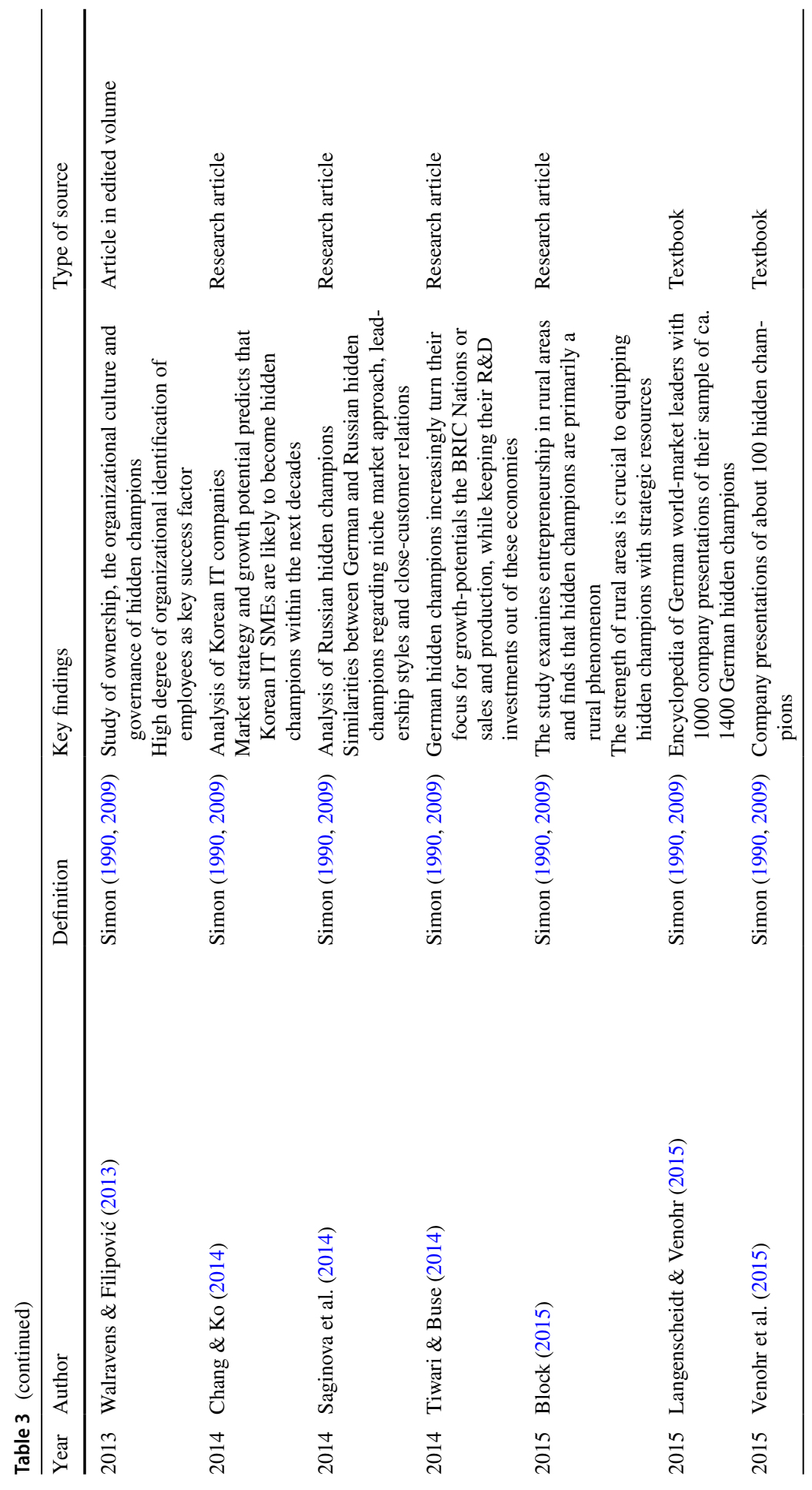




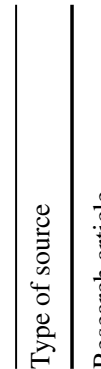

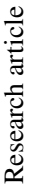

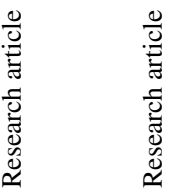

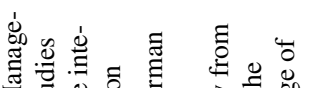

\section{(2)}

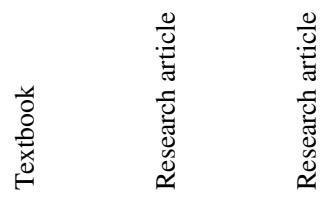

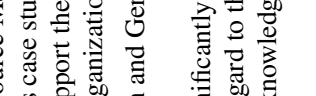

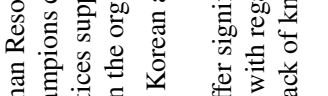

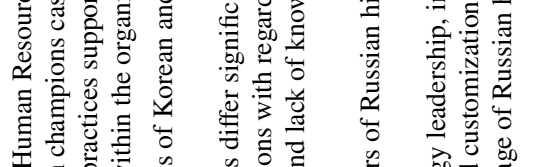

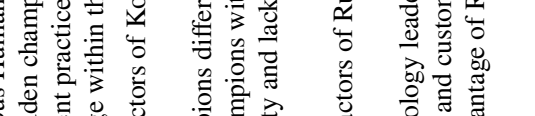

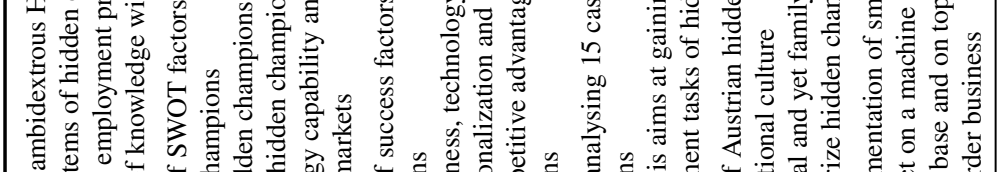

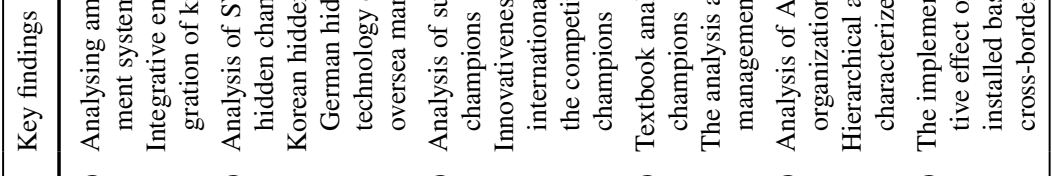

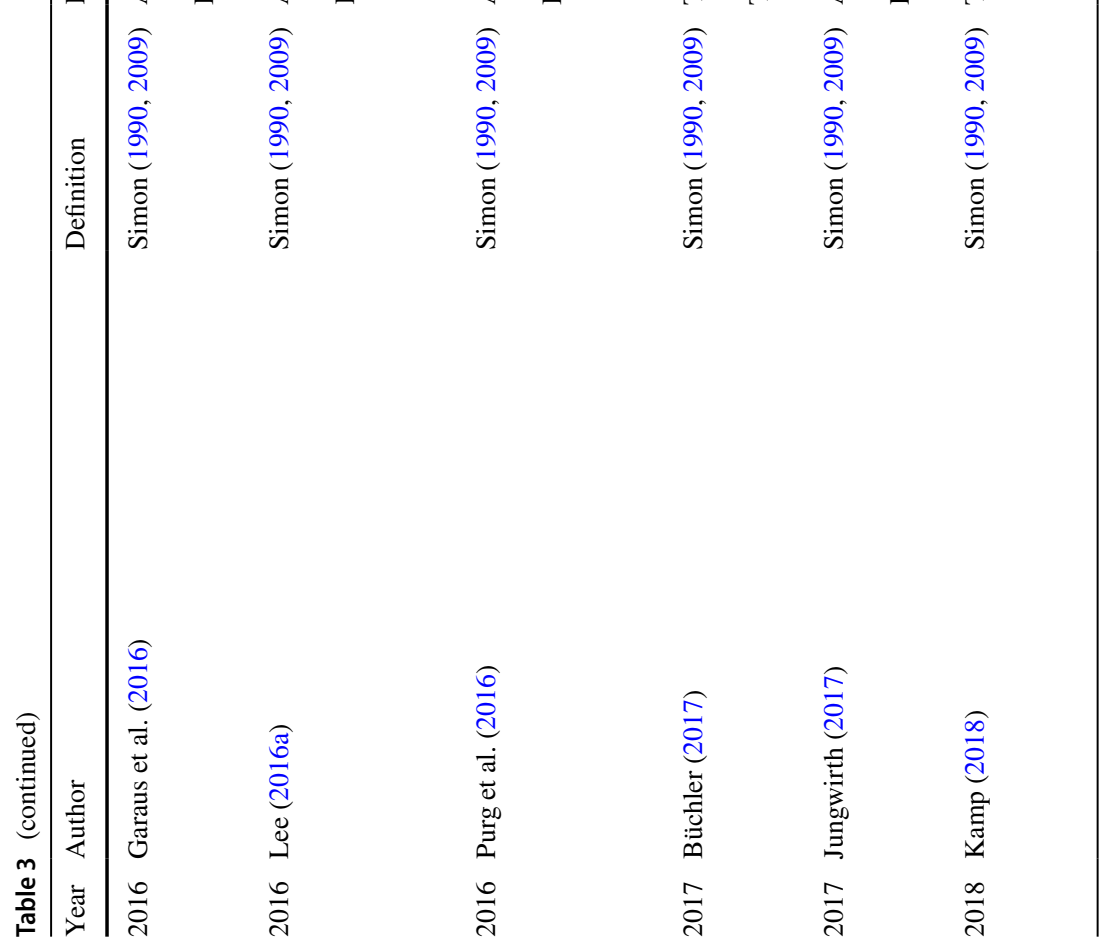




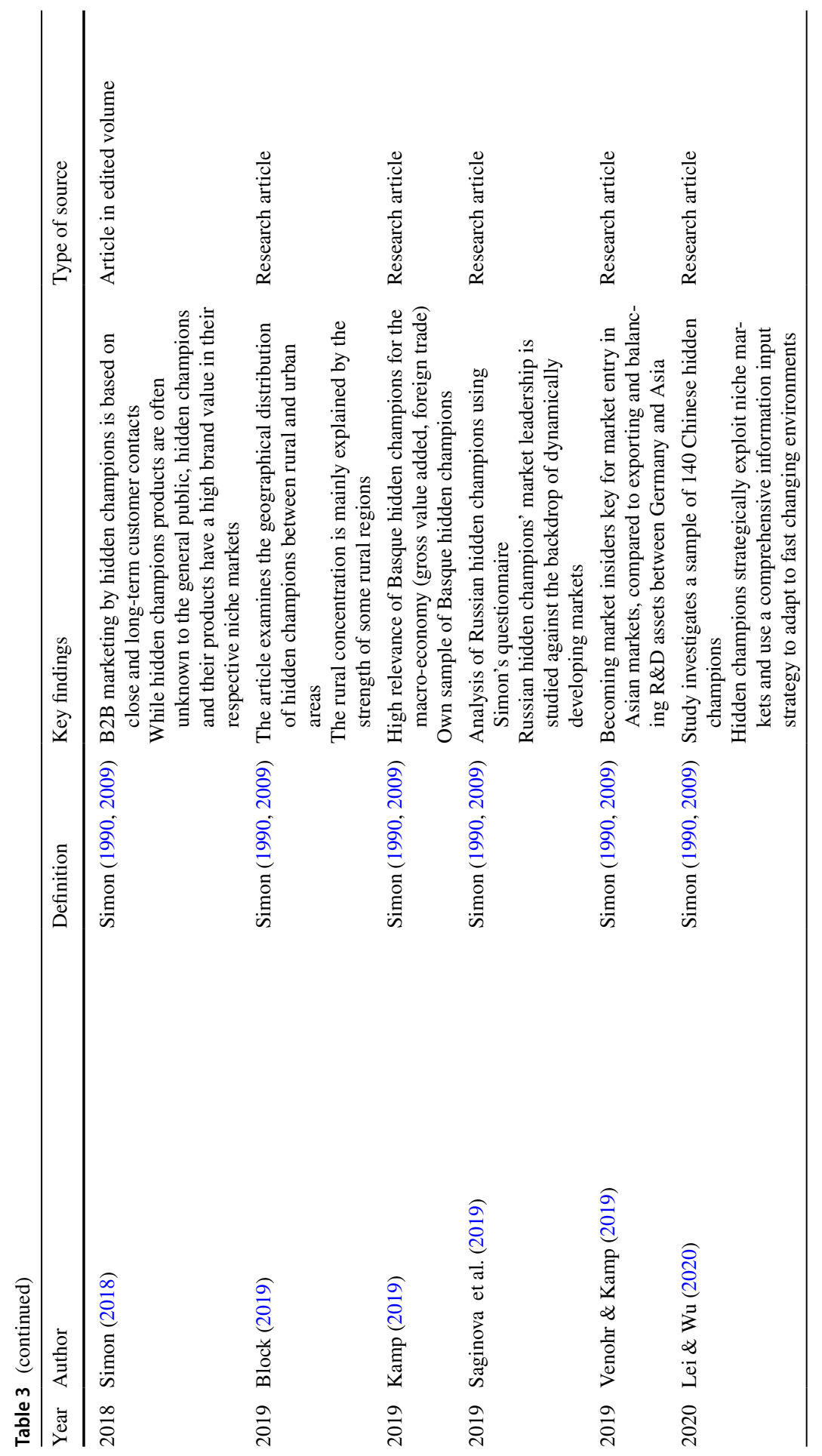




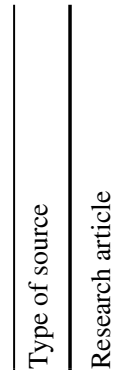

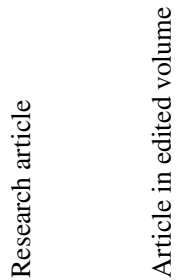

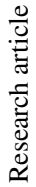

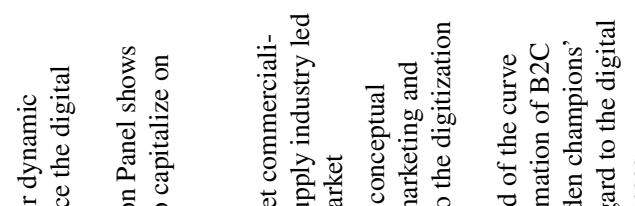

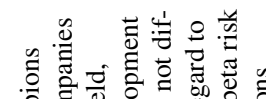

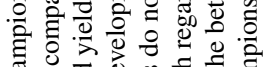

论

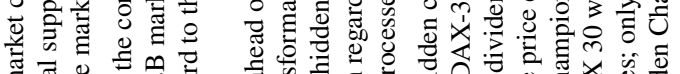

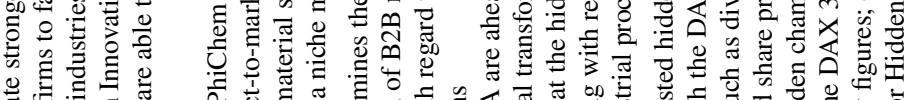

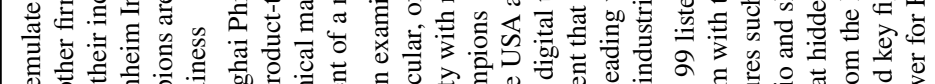



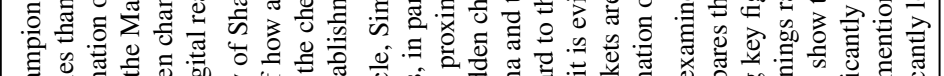

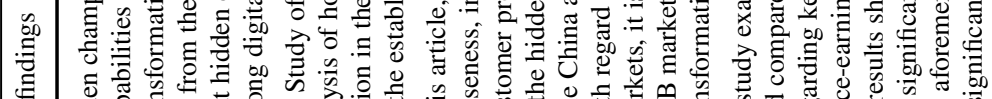

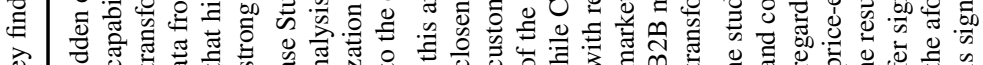

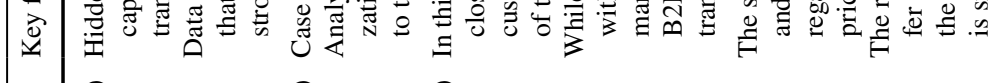

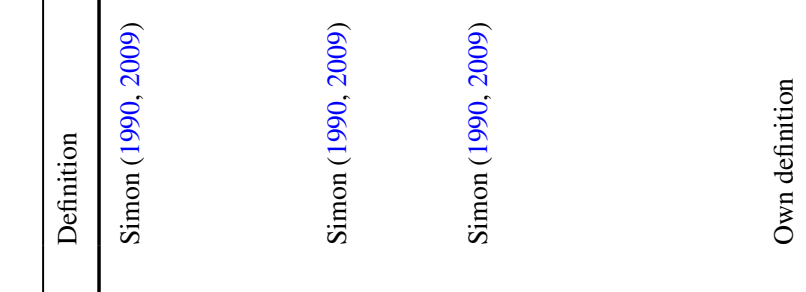

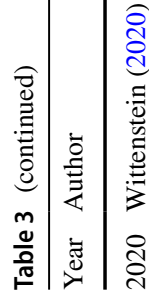

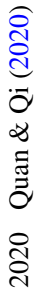

这

ฮิ



$\infty \quad \frac{0}{2}$

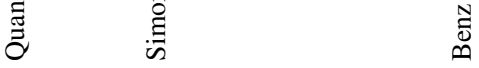

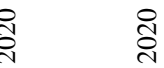

ธิ 


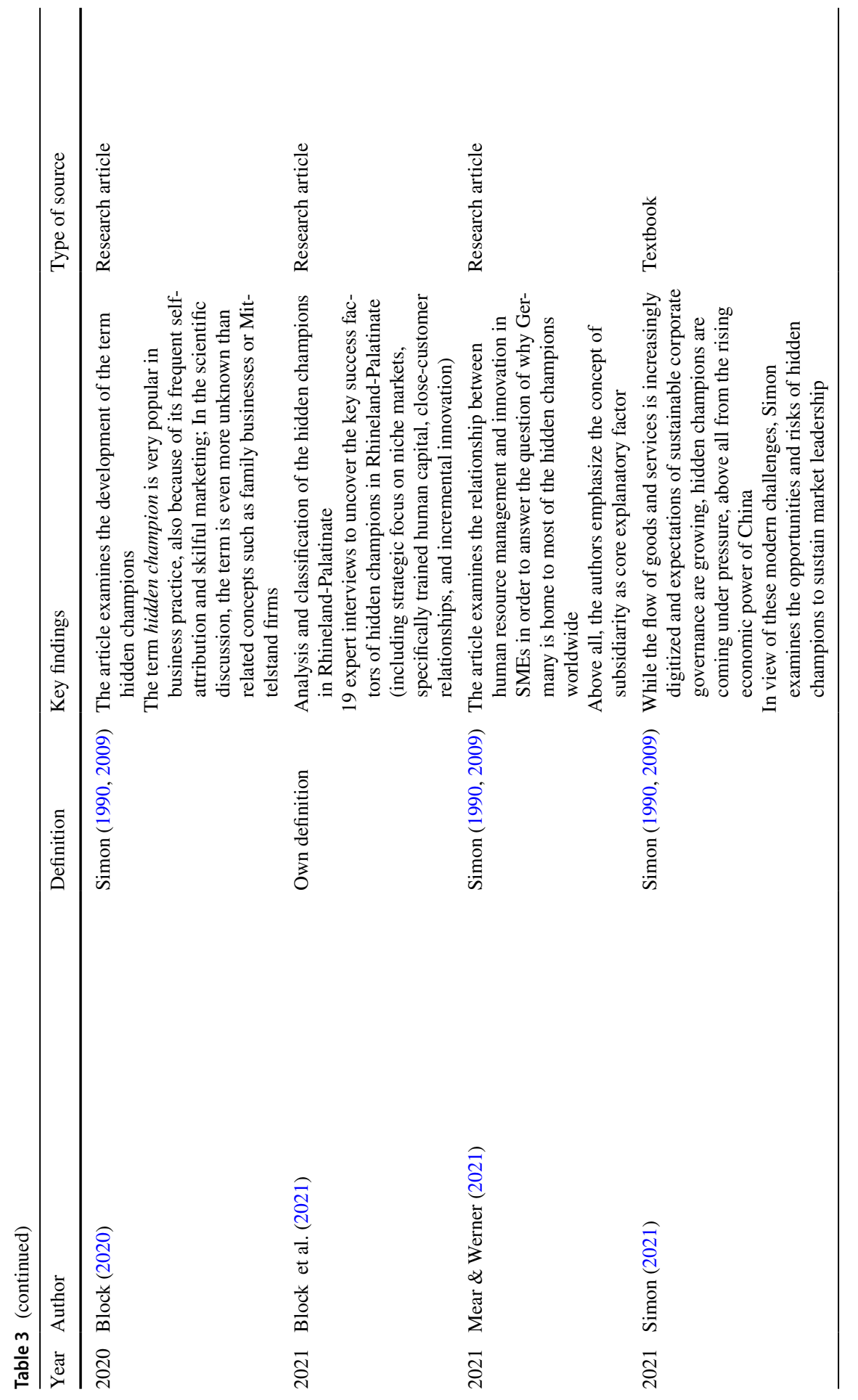


revenue limits of the definition to the growth of the companies (Simon 2009, 2012). Table 1 compares different data collections of niche world-market leaders. Part of Simon's ground-breaking work is a number of strategy recommendations, which explain how to establish and keep world-market leadership of the respective niche market (Simon 1996b). The corporate strategy to endogenously establish niche markets, is complemented by the exogenously given nature of niche markets. To this effect, the hidden champions' niche markets grow generically within their industry and the inherent technological progress. Given the knowledge-intensive, high-tech, and patent-intense nature of niche products, the niche is a result of both specialization and differentiation that in turn erect high barriers to market-entry. The data sample of 1372 hidden champions reveals that $84 \%$ are suppliers in B2B industries (Table 1). Major technical innovations and inventions therefore are commonly pioneered first within mass-markets (e.g., the automotive industry around 1900) that later attract new niches (e.g., car lighting systems) - and therewith establish B2B relationships. Most of the hidden champions emerged during the industrial revolution in Germany and the technological innovations in the mechanical engineering, chemical and electrical industries of the time. In the niche markets of hidden champions, there often are no more than two or three companies competing, which is why world-market leadership (being among the top three companies in the niche market) is often attained as a consequence of the niche market. Research on hidden champions therefore is best analysed through understanding hidden champions as small and mediumsized and mostly family-owned companies that pursue niche strategies. Thus, the characteristic of the niche strategy is the decisive characteristic for research on hidden champions that allows to distinguish hidden champions from other owner-managed SMEs. Moreover, some authors sparked a debate for whether the term hidden champions itself would be an imaginary term and one of the reasons why the research field had a rather hard time getting off the ground (Venohr and Meyer 2007; Kamp 2018; Venohr and Kamp 2019). Additionally suggested terms for hidden champions are International Niche Market Leader (Kamp 2018) or Global Niche Market Leader (Kamp and Venohr 2019).

\subsection{Simon's model}

Simon's model of hidden champions (1996b) describes hidden champions as being characterized by nine core characteristics, which he formulates as imperatives: (1) Set clear and ambitious goals, (2) define a market narrowly, (3) combine a narrow market focus with a global orientation (4) be close to customers in both performance and interaction, (5) strive for continuous innovation in both product and process, (6) create clear-cut competitive advantages in both product and service, (7) rely on your own strengths, (8) try always to have more work than heads and finally, (9) practice leadership that is both authoritarian in the fundamentals and participative in the details. This literature review compares Simon's lessons on hidden champions with further empirical findings from the literature to examine the nature of hidden 
champions and where they differ from small and medium sized family businesses that do not follow a niche market approach.

As already mentioned above, it is often difficult for companies to pro-actively establish a niche market themselves. Here, Simon derives strategic choices that help to establish niche markets themselves. The concern of endogeneity in this vein might also rule that firms adopt to exogenously grown market structures of a certain product. The technological advantage of knowledge-intensive products raises considerable barriers to market entry and therefore help to serve the worldwide niche demand. Moreover, since most world-market leaders export as Born-Globals beginning with the foundation of the company (Witt 2015), the endogenous decision to attain world-market leadership is certainly preceded by the rather exogenously given structure of the niche market.

To further unfold the key characteristics of hidden champions, which distinguish them from other SMEs and other family firms, a few definitions provide a first understanding of the phenomenon. Simon describes hidden champions as firms that rank among the top three in the respective world-market or hold the lead on their respective continent, have revenues below $€ 5$ billion, and a low brand awareness for their products and services (Simon 2012). Simon's definition has become firmly established in the research field, as the overview from Table 3 indicates. 104 of the 112 publications follow Simon's definition of hidden champions. Deviations usually appear whenever authors adapt Simon's definition to their country-specific sample. The sample of Voudouris et al. (2000 p. 664) describes Greek hidden champions as companies that (a) are Greek owned, (b) employ more than 20 and less than 250 employees, (c) are "internationally oriented by either obtaining some of their revenues from outside Greece or by being part of joint ventures or other types of cooperation with companies from outside Greece and finally, (d) they should have achieved excellent performance, for the last five years (i.e. 1993-7) in several financial measures with the main one being the return on own capital". Rammer and Spielkamp (2015, 2019a) specify for their sample that hidden champions must emulate an export share of over 50\% and must also supply customers outside their continent. They are among the top three suppliers in their market, have a market growth (firm sales) of over $10 \%$ within the last five years and have less than 10,000 employees.

The definition of Voudouris et al. (2000) is applied in a study that examines a sample of hidden champions in Greece. Their definition modifies Simon's definition to achieve a sufficiently large sample of hidden champions. Contrary to this, the definitions of Rammer and Spielkamp (2015, 2019a) are far broader compared to Simon and emerge through their top-down sampling approach, which will be discussed more in detail in Sect. 3.3.2. With the restriction to less than 10,000 employees (and not working with a revenue limit), the sample contains significantly more companies than when applying Simon's revenue limit of $€ 5$ billion. This explains why Simon's sample includes 1307 companies (2012) and the sample of Rammer and Spielkamp (2019a, b) 1800 hidden champions. This literature review follows the bulk of the literature and uses Simon's definition to derive the sample of hidden champions, although the $3^{\text {rd }}$ criterion of Simon's definition is derived as an important assignment for future research in Sect. 6 (low brand awareness). Future research 
is mandated to investigate, how the low brand awareness of hidden champions can be measured empirically to allow for better informed decisions on the inclusion or exclusion of firms from hidden champions samples.

\subsection{The Niche strategy from Porter's perspective}

What distinguishes hidden champions from other family businesses and other Mittelstand firms is their niche market strategy. Porter (1980) developed a typology of generic competitive strategies, distinguishing between the dimensions of market segmentation and the nature of strategic advantage. Market segmentation can either be industry-wide or it can focus on a market niche. The strategic advantage can result either from differentiation or a cost leadership strategy. A cost leadership strategy aims to undercut the prices of other suppliers and to align the entire company strategy on cost reduction. In this context, a policy of high volumes aims at achieving economies of scale and standardising production as far as possible. Likewise, comparative cost advantages from cheaper production countries are used and thus much is outsourced over the market with a tendency of lowering the depth of value added. Hidden champions, on the other hand, pursue a differentiation strategy in niche markets. In general, as soon as companies pursue a differentiation strategy, they aim to achieve a competitive advantage through the quality of their products or services. This involves the attempt to secure a monopoly position (in niche markets), since the technological advantage grants them a qualitative superiority, in turn establishing high barriers to market entry. Likewise, premium segmenting reduces the costumers' price elasticity and increases the willingness of customers to pay, since, at least in mass-markets, they buy more than the mere useage of the product (e.g., a pair of jeans for $€ 700$ ). The difference, between the differentiation strategy of hidden champions and companies that differentiate themselves in mass-markets (e.g., premium brands for watches, cars, or fashion), is that these companies have to differentiate themselves in the mass-market through, e.g., their design, in addition to the quality of the actual product. Therefore, the niche market strategy emulates several consequences that shape the nature of hidden champions.

A niche strategy implies a strict focus on a narrowly defined buyer segment with highly specialized needs. Due to the narrowness of niche markets with few suppliers and, especially in business-to-business relations, few demanders, the number of units sold, and the achieved bottom-line revenues are intrinsically limited (Dalgic and Leeuw 1994; Toften and Hammervoll 2010). As economies of scale are difficult to achieve in a niche, niche markets are usually not profitable for large corporations for not providing the volumes necessary to break even (Audretsch et al. 2018). The niches of hidden champions are premium segments, in which they manufacture products of high quality. Their technological advantage is based on high R\&D expenditures and incremental and thus continuous innovation. In their markets, they are monopolists (or one of the few competitors) on a regional or even worldwide base. A strong focus on internationalization is required as growth would be difficult to achieve in their narrow markets without attempting to conquer every market of their niche worldwide. Their narrow markets imply that they often are the sole seller of a certain good or product, 
which explains why they strive to maintain close-customer relations. This characteristic differs from other Mittelstand companies, as their close-customer relationship is rather local and thus driven by geographic proximity. Hidden champions instead find customers worldwide (Simon 2009). For them, the closeness to customers rather stems from a high mutual interdependence and interaction rate (Audretsch et al. 2018).

\subsection{Hidden champions: fields of research}

The following presents the four major streams within hidden champions literature. Each stream is presented with an overview, while a couple of exemplary studies are illustrated in more detail.

\subsubsection{Internationalization strategies of hidden champions}

The first field of research that this review introduces, revolves around the internationalization strategies of hidden champions. Research on family firms points out that risk-aversion and a focus on their local communities lowers the propensity of family firms to internationalize their sales (Zahra 2003). On the contrary, a strong focus on internationalization is typical for hidden champions. World-market leadership of highly specialized niche markets requires to meet large parts of the global demand (Landau, Karna and Täube 2016). The data sample that underlies this review averages the revenues that hidden champions generate through export at $70 \%$. The fewer substitutes that exist for a niche product, the greater the dependence of buyers on the niche company. Niche markets are narrow, as the monopolists in niches have only a few customers (in comparison to mass-markets), which is due to a highly specialized demand. That illustrates why hidden champions are able to serve the world-market as Born-Globals shortly after their foundation (Witt 2015). It is the demand for the highly specialized technology of hidden champions that drives the conquest of foreign markets. To illustrate this with an example, when the Mountain Resort of Lesnaya Skazka, Kazakhstan, was opened in 2018, the choice for a supplier of chairlifts, which is a niche market, was strongly limited. Doppelmayr (Austria) is the world-market leader for chairlifts and has been opening up the foreign market of Kazakhstan, because a highly specific demand for its product had emerged within the respective foreign market. This example of internationalization is typical for hidden champions. At first sight, it seems somewhat exceptional that a company residing in a rural town of only 8,600 inhabitants (Wolfurt, Austria) is able to serve world-markets and establish its market dominance in a country as far as Kazakhstan. Yet, this becomes less of a peculiarity, after having analysed the industry for chairlifts and the internationalization strategies of hidden champions. After the demise of the Soviet Union, Kazakhstan experienced an incredible economic boom averaging its annual GDP growth of $6.63 \%$ between 2000 and 2018. In light of its growing tourist sector, the country began to designate new mountain resorts. Attracting winter sports indeed seems like a complementary strategy to the country's climatic conditions and geographic landscape. The temperature averages minus $20{ }^{\circ} \mathrm{C}$ during Kazakh winters and its highest mountain peaks at 7010 m (Khan Tengri). In order 
to build the mountain resort, an aerial lift system is essential, for which the region's council was likely to announce a public tender. The market for aerial lifts is a typical niche market and is characterized by a complex and demanding technology and for obvious reason needs to maintain high quality and safety standards. Moreover, the market for aerial lifts exhibits strong monopolization, which is typical for niche markets. While Leitner (Italy) and Pomagalski (France) control 30\% together, the worldmarket leader Doppelmayr Garaventa (Austria) controls $60 \%$ of the market and won the public tender for Leznaya Skazka (Doppelmayr 2019).

While Simon (2009) argues that foremost the global mindset of hidden champions would enable their internationalization and building of market-coverage, Audretsch et al. $(2018,2021)$ point to the character of the niche market that drives the hidden champions' internationalization strategy. The authors elaborate that in a market of only a few suppliers, technology dependence is the main reason to match demand and supply. A global mindset instead is a characteristic that rather seems to be important in mass-markets, where suppliers need to adapt to local tastes and other cultural traits (Nummela et al. 2004; Ramsey et al. 2016). Competition, for hidden champions, exists mainly within the oligopoly and potentially through entrants into the niche market. Yet, the latter is unlikely due to high barriers of entry (technological edge, specific human capital base of the workforce, strong use of patents, longterm, and close-customer relations etc.). The market concentration of niche markets exerts pressure on the incumbents to not lose market share to the few competitors, as this could drive the incumbent out of the market (crowding out in oligopolies, see McEachern 2011). A niche strategy therefore naturally involves intense internationalization for each market that exhibits a need for the product. Consequently, the psychological, cultural and physical distance to the foreign market plays a subordinate role in niche markets, because the dependence on the often sole producer matches the market and thus drives the patterns of internationalization. In this respect, hidden champions differ significantly from other family businesses and thus represent an anomaly to the literature on family businesses, which states that family firms typically internationalize less extensively, as described above. In support of these considerations, several studies have analysed the internationalization strategies of hidden champions (Fryges 2006; Witt 2015; Audretsch et al. 2018).

Audretsch et al. (2018) investigate the internationalization strategies of hidden champions through the lens of property rights theory. The authors point out that a strong vertical integration is necessary for hidden champions to protect themselves from knowledge drain and to keep quality standards. Vertical integration is essential to reduce the number of contracts concluded over the market to a minimum (Grossman and Hart 1986; Demsetz 1988; Holmström and Tirole 1989; Hart and Moore 1990, 2005; Brynjolfsson 1994; Roberts 2007). Market transactions are pareto-inferior to transactions within the boundaries of the firm, whenever firm assets and their investments are highly specific. Considering the incompleteness of contracts, potential contingencies with market-based contractual parties then could only be averted at great expenses. For this reason, the internationalization of hidden champions foremost takes place by means of direct export and a large number of entirely owned subsidiaries (Haussmann 2003; Witt 2010), since the specificity and thus the technological intensity of the assets make it necessary to secure unequivocal property 
rights (Acemoglu et al. 2010; Antràs and Chor 2013). Fryges (2006) adds to that and investigates the anomaly that hidden champions export very strongly despite the fact that they are SMEs. In his study, he finds that neither a low firm age nor a small firm size is an obstacle to emulate a high export intensity. What distinguishes hidden champions from other SMEs are firm-specific assets that they use to overcome obstacles of foreign market entry. For the development of the firm-specific assets, it is necessary to invest more than non-hidden champions in $\mathrm{R} \& \mathrm{D}$, to buy technologies from other companies or to hire managers, with a high experience in the internationalisation of companies. Finally, Witt (2015) analyses the internationalization strategies of British and German hidden champions and the form of market entry into foreign markets. According to Witt, no hidden champion within her sample, follows the Uppsala model, while $43 \%$ can be characterised as Born Globals and are already active worldwide shortly after their foundation. All of the Born-Global hidden champions prefer direct export as mode of market entry (Witt and Carr 2013). Relying on their own assets grants them to retain high degree of control, which is essential to protect their technological advantage and the high quality of their products. Her study shows that $20 \%$ of her sample of British and German hidden champions can be categorized as Born Again Globals (BAG). This implies that firms initially serve domestic markets until a critical exogenous shock spurs "belated accelerated internationalisation" (p. 285). 37\% prove to be hybrid arrangements between the latter modes of entry.

Drawing a conclusion, the literature on the internationalization strategies of hidden champion agrees on the high importance of vertical integration, when entering foreign markets. Hidden champions rely on the boundary of the firm to safeguard the incentive for specific investments. In doing so, hidden champions are better able to internalize the quasi-rent within their own hierarchy and thus largely avoid contracting over markets. Subsidiaries and direct export grant independence from less third-party involvement, which allows to enforce the corporate strategy and protect knowledge and quality standards. The high value-added strategy allows to circumvent the incompleteness of contracts and its threat of hold-up and renegotiation (Coase 1937).

\subsubsection{R\&D and innovation strategies of hidden champions}

Apart from the internationalization strategies of hidden champions, most studies on hidden champions analyse their R\&D and innovation strategies (Venohr and Meyer 2007; Yoon 2013; Rammer and Spielkamp 2015, 2019a). The reason why research mostly examines the latter fields is obvious. The niche strategy of hidden champions places innovation and internationalization at the forefront, as both fields are key to their competitiveness and determine market-leadership (Zastempowski 2011). Hidden champions tailor technologically demanding and knowledge-intensive products, mostly in B2B markets. Technology leadership is key to keep their position as a market-leader. Their strategy of innovation thus can be described as rather incremental than radical (Henderson and Clark 1990). To this effect, the framework of Henderson and Clark allows to classify various types of innovation according to the novelty of the innovation. The authors distinguish between architectural, radical, 
modular and incremental innovation. Radical innovations are characterized through a strong overall novelty of the product. The novelty of the latter manifests itself in a new design, relies on new components, and needs to be implemented through a newly built system architecture. Of course, moving into uncharted waters requires a higher risk to be borne. Hidden champions instead have no need to disrupt their own markets and rather pursue incremental innovation. The incremental innovation refers to the development of individual components of a core concept that remains unaltered otherwise. Technological improvements are primarily made to satisfy customer needs, to increase customer loyalty, and to safeguard technology leadership (Voudouris et al. 2000; Riisalu and Leppiman 2013).

Although a hidden champions' product invention, obviously, was a radical innovation, hidden champions focus on incremental innovation afterwards. Their innovation strategy is driven by the close-customer relationship and the strong interdependence inherent in the market relationships to their customers. The high interaction rate and technological specialization allow customers to intensively contribute to the innovation process with their own knowledge about the hidden champions' product (Baloh 2013; Rant 2013b). Lending from the property rights perspective further above, the hidden champions' strategy of differentiation both explains the important role of $R \& D$ and innovation and why hidden champions are vertically integrated to a great extent (Rant and Cerne 2017b).

The technological complexity of the hidden champions' niche offer requires to tailor products to the specific use of customers. These knowledge intense industries (mechanical engineering, electrical engineering, chemicals, medical engineering etc.) imply that hidden champions need to protect their intellectual property both through vertical integration and strong patenting efforts. Both is essential to defend their leading market position. Differentiation strategies aim at technological leadership and offering quality products to highly specialized customers. This explains why hidden champions continually foster incremental innovation. The vertical integration therefore is necessary for quality control, as hidden champions largely avoid to depend on market transactions and third party influence (Voudouris et al. 2000; Baloh 2013; Riisalu and Leppiman 2013).

Especially within this stream of research, some studies not only collect samples of hidden champions, but additionally form a control group to compare the innovativeness of hidden champions to other firms. The groups are compared in statistical tests to derive implications regarding the peculiarities of hidden champions compared to other family firms and SMEs. Examples include the studies by Rammer and Spielkamp (2015, 2019a) and Schlepphorst et al. (2016). Rammer and Spielkamp (2015) examine the innovation strategy of German hidden champions. In contrast to most other empirical studies on hidden champions (bottom-up sampling), Rammer and Spielkamp (2015) use a top-down approach to form their own sample of hidden champions. As described above, they use their own (and broader) definition of hidden champions and find 1,583 hidden champions in Germany within their 2015 sample. With propensity score matching, a control group is built to test their assumptions. The findings show that hidden champions innovate more than the control group. In their second study on hidden champions (2019a), again, they use a top-down approach to obtain their sample of hidden champions, where the 
total number of hidden champions in Germany is extrapolated in a stratified random sample. Within this estimation approach, they find 1,800 hidden champions, building their base to work out distinct success factors regarding the hidden champions' business strategy and innovation management. The authors conclude that hidden champions pursue an innovation-based business strategy, and that the hidden champions' global market leadership is based on technological superiority and high customization. Contrary to Simon's analysis, hidden champions do not spend more on R\&D than the control group, but still emulate a higher level of innovation. Rammer and Spielkamp conclude that hidden champions achieve a particularly efficient use of resources, and that this strength is based on four factors: a high focus on the development of their technology, open innovation and strategic networking of their knowledge base, a complementary management of their intellectual property, and finally high investments in the human capital base of their employees.

In another study, Schlepphorst et al. (2016) investigate determinants that distinguish hidden champions from other firms. They form their own sample of German hidden champions by selecting from a large database of companies in which they separate hidden champions from non-hidden champions by criteria similar to Rammer and Spielkamp. Among other factors, they base their selection on the companies' own statements as to whether they are market leaders in Europe or among the top three global market leaders in their segment. Finally, they apply logistic regressions to test factors that distinguish whether a company is part of the hidden champions sample and not part of the control group. On the basis of 60 hidden champions and 346 non-hidden champions, they find that research and development, international business activities, and a great ambition to maximise market shares are characteristics that significantly distinguish hidden champions from other companies.

Venohr and Meyer (2007) examine the long-term evidence of the hidden champions' leadership, development and strategies over a period of ten years and base their analysis on Simon's set of German hidden champions. They find empirical evidence that hidden champions are especially characterized by family ownership and a family cooperative culture that often is combined with outside professional management, a global market dominance pursuing a niche market approach, and thus the exploitation and enhancement of resources and capabilities on a global scale. Finally, they find that hidden champions are intensively occupied with increasing their operational effectiveness of major processes and functions. These factors altogether explain the organizational fit of hidden champions for their innovative product output and the technological leadership. Yet, another example is Yoon (2013), who examines the R\&D and innovation strategies of hidden champions in Korea and finds that hidden champions have more market initiative, technology competence and internationalize stronger than non-hidden champions. Among his sample of hidden champions, he divides between born and acquired hidden champions and finds that born hidden champions show higher innovation, internationalization and patent rates compared to acquired hidden champions. Yoon bases his findings on his own sample of Korean hidden champions and performs t-tests to test his hypotheses against the control group of medium-sized non-hidden champions. Adding to Venohr and Meyer (2007) and Yoon (2013), Kaudela-Baum et al. (2014) examine the determinants of the hidden champions' 
high innovativeness. They attribute the strong innovativeness of hidden champions primarily to their corporate culture, which motivates employees to develop ideas and pro-actively pass them on to the management. The decentralization of decision-making creates incentives for employees to pro-actively initiate product development. Thus, employees in hidden champions are more involved in the innovation process than in other companies, creating an organizational climate that particularly encourages innovation.

To sum up the literature on the R\&D \& innovation behaviour of hidden champions, the niche market approach entails that hidden champions produce highly specialised products with a high focus and relatively low product diversification. This specialization requires the development of a deep knowledge base, which is generated through $\mathrm{R} \& \mathrm{D}$ and the collaboration with long-term customers. On average, hidden champions patent significantly more than the companies listed on the German DAX30 index, with 31 patents for every 1000 employees, DAX30 companies on average have only 6 patents per 1000 employees (Simon 2009). Are hidden champions therefore really more innovative than large corporations and other family-owned businesses?

The answer to this question is not unequivocal. Just because companies patent more, does not prove that they actually are more innovative. There are good reasons why companies do not patent despite of being highly innovative. Patents formalize knowledge and thereby make knowledge public for other companies and potential market-entrants. Market incumbents thus may even risk their market leadership. Therefore, comparing innovativeness with mere patent figures is not entirely reliable, because the measurement of innovation through patents can suffer from shortcomings (Shepherd 1979; Acs and Audretsch 1989). Nevertheless, hidden champions face only little competition within their market niche. Thus, they indeed could patent more than other companies, as the threat of product imitation in niche markets is limited. However, Venohr and Meyer (2007) argue that their markets are contestable in the long run. As long as substitutes are available, new competitors can enter the niche market, as soon as it becomes profitable for them. Still, this holds only partly, especially since the narrow market provides too little volumes for large corporations and thus market entry would be rather likely for young and small companies. What distinguishes hidden champions from other Mittelstand and family-owned companies is that they are technology leaders in their product niche. The continuous development of their technology is often carried out in close cooperation with the needs and suggestions of the customers. In narrow niche markets, suppliers and customers are exposed to a high degree of interdependence and thus often work together on a long-term basis and in close ties. As a result, customers have a large share in the ongoing development of the product through their expertise of highly technological products. Hidden champions spend an average of $5 \%$ of their sales on $R \& D$, which is even higher compared to the manufacturing companies in the Global Innovation 1000 (4.5\%), an index that tracks the most innovative and R\&D companies worldwide (Venohr and Meyer 2007; Simon 2009). Technology leadership in niche markets is a key factor that explains why hidden champions offer products of both high quality and prices and thus differentiate themselves from many other Mittelstand companies. Although patent statistics do not necessarily prove innovativeness, 
the niche approach, the technology leadership and high R\&D spending suggest that innovativeness is a specific characteristic of hidden champions.

\subsubsection{Geographic distribution of hidden champions}

A third and still rather small field of research explores the geographic distribution of hidden champions. So far, the analysis has centred on the historical origins of Germany's Mittelstand (Audretsch et al. 2018), the system of vocational education (Lehmann et al. 2019; Audretsch et al. 2021), the inheritance tax regime, the system of corporate boards, and geographic economics (Audretsch et al. 2021) to study the worldwide distribution of hidden champions. Finally, another study investigated the dual system of higher education and the regional distribution of hidden champions in Germany (Schenkenhofer and Wilhelm 2020).

Audretsch et al. (2018) show that hidden champions predominantly belong to those industrial sectors that served as the leading sectors during the German industrialization in the second half of the nineteenth century. The technological development and innovations of this time established technology and thus world-market leadership, which has been maintained in the respective industries ever since (in particular mechanical engineering, the chemical industry, electrical and medical engineering). Lehmann et al. (2019) focus on the centralization of vocational systems and point out why the specific human capital of vocational apprentices proves to be complementary for hidden champions. The authors show that in centralized VET systems, human capital investment is provided publicly and thus employees are incentivized to invest in their stock of specific human capital. In decentralized VET systems, public spending on vocational education and training is limited, which is one reason for a rather low number of hidden champions. The authors thus attribute the distribution of hidden champions to the availability of an economy's stock of complementary (firm-specific) human capital. Centralized VETs reduce the underinvestment of employees in their specific human capital. By investing in firm-specific human capital, employees lock themselves in with the employer and thus reduce their outside opportunities with other firms in the labour market. Therefore, employees commonly are reluctant to invest in their specific-human capital base. Contrary to that, if training is organised by the state and the investment publicly funded, employees are more willing to invest in their specific human capital base. Moreover, a centrally organized certification system also leads to a reduction of lock-in effects and a higher transferability of labour, which likewise increases investments in an economy's stock of specific-human capital. A further study within this field of research is by Audretsch et al. (2021). In their context-choice model, Audretsch et al. (2021) explain the emergence of niche entrepreneurship within national economies around the world. In their model, the authors describe various context variables, such as soft inheritance taxation, dualistic corporate board systems, civil law regimes and therefore underdeveloped traditional and venture capital markets, the low cluster intensity of a country's economic geography and the centralization of the VET system as complementary to the organizational choice variables of niche entrepreneurs. They substantiate their assumptions through negative binomial regressions for 217 countries. Finally, Schenkenhofer and Wilhelm (2020) 
examine the geographical distribution of hidden champions in Germany and find that Baden-Württemberg concentrates most of the hidden champions in Germany. In this context, the authors examine the system of dual higher education in BadenWuerttemberg and its capability to stimulate the stock of specific human capital in Baden-Wuerttemberg. Another promising subfield within the stream of economic geography examines the importance of innovative businesses such as hidden champions for the development of small towns in peripheral locations (Vonnahme et al. 2018; Lang et al. 2019; Vonnahme and Lang 2019) and for regional economic development (Benz et al. 2021).

\subsubsection{Other}

A good number of other publications cannot be categorized easily within the typology of this literature review and rather present marginal topics, as Table 3 shows. Plenty of articles within this fourth field of hidden champions research explore the concepts of Simon and test empirically how certain countries' hidden champions compare to Simon's German sample. The authors usually build a sample of local hidden champions and use surveys to analyse their country's case. The conclusions are derived from mostly descriptive analyses and are interpreted in comparison to Simon's findings. The study by Voudouris et al. (2000) is a typical example of early empirical works within the research field of hidden champions, as it sets up a new sample of world-market leaders for a certain region (Greece in this case) and empirically investigates the success factors that are key to their business strategy. They find that Greek hidden champions are constituted mainly by their high degree of specialisation in narrow market segments, a high commitment to customer service, a culture that fosters innovation and the adaption of new technologies and finally a strong leadership and a healthy organizational climate. Similar to the study by Voudouris et al. (2000), a few studies from the Southeast European region, Russia and Kazakhstan investigate hidden champions descending from emerging markets (McKiernan and Purg 2013a). They use Simon's questionnaire to examine the core characteristics of the identified hidden champions in their countries and compare them with Simon's findings. In total, researchers from 18 countries participated in the survey and found 165 hidden champions, with a much younger average firm age of only 19 years. The export rates of the samples are almost identical to those of Simon's sample (Table 1). Examples of these studies are Brkic and Berberovic (2013a, b) or Lebedev (2013). Brkic and Berberovic (2013a, b) study the marketing strategies of hidden champions of the CEE region and find that hidden champions are able to secure a quality brand position without the usual trade-off between rapidity and quality. Hidden champions achieve to transfer the brand value from their customers to their own brands within B2B markets. Lebedev (2013) studies the financial strategy of hidden champions of the CEE region. In contrast to Simon's sample of German hidden champions, hidden champions in the CEE region need more external finance for growth, which still rests in an early-stage phase. The underdeveloped financial markets prove to be the major economic obstacle for hidden champions within the CEE region. 
Other exemplary studies that focus on more marginal aspects of hidden champions research are Kirner and Zenker (2011) or Garaus et al. (2016). Kirner and Zenker (2011) investigate the role of knowledge angels for the corporate success of hidden champions. Knowledge angels contribute special expertise to the company and thus combine internal and external knowledge, which is particularly beneficial for the technological advantage of hidden champions. Garaus et al. (2016) analyse ambidextrous Human Resource Management systems using case studies of hidden champions. They find that integrative employment practices support the integration of knowledge within the organization.

\section{Hidden champion and research on the German Mittelstand}

After Sect. 3 has examined research on hidden champions, another objective of literature reviews is to elaborate which other research strands are linked to or subordinate the given field of research (Hart 2018; Webster and Watson 2002; Gabbott 2004; Torraco 2005; Pautasso 2013). The nature, behaviour and performance of hidden champions can also be accessed through Mittelstand research, especially since the vast majority of hidden champions are Mittelstand companies and thus the research field of hidden champions can be integrated into the research on the Mittelstand. Much of what has already been found for Mittelstand companies applies to hidden champions. On the other hand, there are certain particularities which distinguish hidden champions from other Mittelstand companies. The delineation from Mittelstand research thus helps to elaborate the full essence of hidden champions. While Anglo-American research often tends to simply consider Mittelstand companies as SMEs, the term Mittelstand describes more than a quantitative classification and is characterized by distinctive qualitative characteristics. Figure 1 describes the overlap of the different concepts. SMEs are constituted first and foremost through the definition of size, defined by the IFM as companies with fewer than 500 employees and an annual revenue of less than $€ 50$ million (IFM 2020b). On the contrary, the IFM defines Mittelstand firms "by the unity of ownership and management. (...) In a medium-sized company, up to two natural persons or their family members (directly or indirectly) hold at least 50\% of the shares of a company", whereby they are members of the management. Furthermore, the "intersection of medium-sized enterprises/family enterprises and independent small and medium-sized enterprises (SMEs) is very large". It is also significant here that according to the IFM, "companies with 500 or more employees or annual sales of more than $€ 50$ million also count as Mittelstand/family businesses", if they meet the criteria of the definition (IFM 2019). E.g., hidden champions such as the Aerzener Maschinenfabrik GmbH, is a Mittelstand company, as it is owner-managed, in spite of its 2,243 employees and revenues of $€ 382$ million. And companies like GEA Group AG (18,642 employees, $€ 4.8$ billion revenues) or ElringKlinger $A G$ (10,033 employees, $€ 1.7$ billion revenues) are hidden champions (following Simon's definition) even though they do not belong to the Mittelstand regarding both definitions, as they are not owner-managed and surpass the employee and revenue limit. 


\subsection{Qualitative dimensions of the Mittelstand}

In recent years, entrepreneurship research has endeavoured to describe and compare the heterogeneity of different types of entrepreneurship (Welter 2011; Welter and Gartner 2016; Welter et al. 2016; Welter et al. 2017; Audretsch 2019). Thus, the Mittelstand is a type of entrepreneurship model, which has gained a lot of attention from leaders in policy and business throughout the world, because of its economic resilience, among other reasons. Often, the Mittelstand is described as the backbone of the German economy and stands out as an engine for Germany's innovativeness and export success (Audretsch and Lehmann 2016). German's industrialization and the rise to global economic power is, above all, also a story of the emergence and rise of the German Mittelstand. This section illustrates its qualitative characteristics, which later are compared to the hidden champions. A number of authors have described the qualitative factors that characterize the German Mittelstand (Berghoff 2006; Welter et al. 2014a, b, 2015; Audretsch and Lehmann 2016; Pahnke and Welter 2019a). Here, it is important that the criteria overlap as little as possible. The model clusters the criteria into three main categories: (1) Governance, (2) Culture andValues and (3) Economic Key Strategies. Some facets of Mittelstand companies have also been analysed within the family firm literature, because they accrue to family firms just alike.

\subsection{Governance}

Identity of ownership and management. One characteristic of the Mittelstand is the identity of ownership and management (Jensen and Meckling 1976; Welter et al. 2014a), which is one of main focal points within family firm research. In this context, it is important to distinguish analytically between large family businesses, which Mittelstand world-market leaders usually are, and smaller businesses. The Mittelstand comprises $99.6 \%$ of all companies in Germany. At this point, it is to emphasize that one-man businesses and other self-employments, such as electricians, master painters or other main street businesses are included within this figure (Glauser 2016). For these businesses, agency problems, such as the extraction of private benefits of control and the hiring of professional managers, occur to a smaller extent (Ross 1973; Eisenhardt 1989; Schulze et al. 2001). Yet, for all family firms alike, management succession is considered as a pivotal challenge, particularly in the wake of the demographic change in Western industrialized nations. The preservation of family control is a central characteristic of family businesses (CabreraSuárez et al. 2001; Bennedsen et al. 2007).

Patriarchal leadership. For larger companies of the Mittelstand, the leadership style is often patriarchal and authoritarian (Simon 2009; Audretsch and Lehmann 2016). The strategic alignment is determined by the top management, who often delegate decision-making authority on the operational level to the lower management. The decentralization of decision-making authority has a motivating effect on employees and strengthens the family climate in the company. 
Long-term planning horizons. Mittelstand companies are particularly characterized by long-term planning and investment horizons, which is often reflected in the deep knowledge base of the company (Berghoff 2006; Audretsch and Lehmann 2016; Pahnke and Welter 2019a). On the contrary, the contracts of professional managers often have a short duration of only 4 or 5 years. Tying remuneration to the share price may encourage managers to plan investment returns in a way that the associated performance effect occurs within their contract period. This fosters investment-decisions to be made below optimum. Instead, the management continuity in Mittelstand companies implies that consistent strategies can be pursued in the long-term and therewith sensitive and tacit assets can be built up, e.g., like a family business culture. In this context, the fact that employees of Mittelstand companies are also characterised by high employee loyalty and low and therefore costsaving turnover rates, has a complementary effect. This, in turn, makes it possible to build strong social ties between employees and pronounced social networks within the company (Audretsch et al. 2018). The mutual planning security and long-term nature of the ties promote the confidence for relation-specific investments in the human and social capital of employees, since quasi-rents are safeguarded in an interdependent relationship (Williamson 1975; Hart 1988).

\subsection{Culture and values}

Tradition and family dynasty. The continuation of family traditions and the preservation of the dynasty are essential characteristics of the cultural self-image of Mittelstand companies (Welter et al. 2014b; Welter 2018). Growing up in a family firm, is an integral part of the construction of the family members identity and construction of self. This is nurtured by shared experiences, stories and traditions that grow over generations and have a decisive influence on the family's foundation of values (Deephouse and Jaskiewicz 2013). Organizational identification thus refers to the oneness of an agent with its organization regarding the congruence of shared values and beliefs that induce an alignment of goals (Mael and Ashforth 1992) and leads to a higher level of attachment of family members to the firm than for non-family members.

Emotional attachment. Strongly linked to the latter characteristic, the emotional attachment to the family business describes the willingness of a member of the family to be a recognized member of the managing family. The attachment to the family is characterized by a strong affection for the family and the desire to subordinate one's own interests to the welfare of the family (Welter et al. 2015). The willingness to belong to a group is essentially based on fulfilling and defending the values and standards of the group (Bowlby 1979; Paxton and Moody 2003; Thomson et al. 2005; Zellweger and Astrachan 2008).

Family climate. Mittelstand firms are often distinguished by a family climate in their corporate culture (Welter et al. 2014b; Welter 2018). In addition to the dense social networks and low fluctuation as mentioned above, this is also due to the proximity of the leader and employees. Due to the small or medium size of the company, the frequency of contact with the leader is significantly higher, which makes 
employees feel perceived better. Moreover, flat hierarchies also help to communicate bottom-up to the management level and the individual employee thus can be heard more easily. Similarly, flat hierarchies help employees to feel that they have a greater direct involvement in the success of the company, which is a symbol of how close the company and its leaders are to employees (Björnberg and Nicholson 2012; Cabrera-Suárez et al. 2014).

\subsection{Economic key strategies}

Economic independence. Mittelstand companies often maintain a high equity ratio and are usually not listed on the capital market, which grants them a certain independence from economic cycles and increases their autonomy in terms of capital supply (Berghoff 2006; Welter et al. 2015; Audretsch and Lehmann 2016). In Germany, the house bank principle has proven its worth for Mittelstand companies, which describes the close cooperation of a Mittelstand company with a local bank (communal saving banks and credit cooperatives) in a long-term partnership (Vitols 2001; Reinemann 2019). The cooperation is characterised by mutual trust, whereby the banks usually interfere with the strategic alignment of the company to a limited extent. Rather, the bank serves as a quick and convenient cooperation partner for financing models and source of liquidity. Mittelstand companies also secure their economic independence through vertical integration. In this regard, the significance of the depth of value added grows alongside to the knowledge intensity, technological complexity and innovativeness of the product. As described further above, market contracting is inferior to integrating value creation within the hierarchy of an organization, in case of highly specific investments and a thus high sensitivity of information on the product. The boundaries of the firm thus are vertically integrated, if market transactions cannot be sufficiently protected by (incomplete) contracts due to the high specificity of the investments (Williamson 1975). Retaining property rights over assets is critical, because they lend bargaining power to their ownerespecially in case of transaction contingencies and assumed opportunism and the potential hold-up of contractual partners-as discussed further above (Grossman and Hart 1986; Demsetz 1988; Holmström and Tirole 1989).

Nimbleness. Mittelstand firms often are very dynamic firms that find it easy to adapt to environmental changes (Berghoff 2006; Audretsch and Lehmann 2016; Welter 2018). They achieve nimbleness through a lean organization and flat hierarchies. A quick and non-bureaucratic administration allows for fast reactions and adaptations to the needs of customers and market changes. Ideas from the lower levels of the hierarchy, which are often closer to the operational business, can thus be passed on to the management with relative little loss of information compared to organizations with steeper and more complex hierarchies. The broader base has more intensive and more frequent contact with more customers than in very steep hierarchies, where sometimes only top managements tend to exchange information among themselves. This offers the possibility to be open for external knowledge at many access points. In addition, more employees at lower hierarchical levels are equipped with higher levels of competence than in large corporations, for example. 
This in turn inspires employees to pass on their ideas for product and process development (Welter et al. 2014b).

Close-customer relations (local). Mittelstand companies often build long-term relationships with customers, which allows for establishing mutual trust (Audretsch and Lehmann 2016; Glauser 2016). The often local proximity between companies and customers strengthens customer loyalty and enables frequent and close-customer contact. The frequency of interaction between customers and companies promotes to obtain mutual knowledge of the product range, which helps to address customer needs specifically. Moreover, in rural areas, the lack of alternatives in smaller markets leads to a natural dependency between companies and customers, which further strengthens the bond between them through the lack of outside opportunities. The narrow geographical space between companies and customers also implies a high visibility of the company's quality and reliability for other customers, since in narrow social networks, customers can strengthen or weaken the company's reputation decisively through word-of-mouth recommendation.

Strong regional ties. Due to close-customer contact and often limited economic resources in rural areas, Mittelstand companies are dependent on investing in their local communities and working closely with local politicians (Welter et al. 2014a). In this context, the concept of corporate citizenship describes the commitment to social activities in the company's local environment that exceed the actual business activity (Carroll 1998; Matten and Crane 2005). Mittelstand companies aspire to be recognized by society as corporate citizens and to be seen as partners of society. This implies that they do not cut back on social resources, but rather regard them as their own resource base, which they must constantly nurture. In this way, companies contribute pro-actively to solve social problems and give something back to society from their profits. Some corporate citizenship instruments include, for example, donations, sponsoring, corporate charitable foundations, corporate volunteering or organizing local social events to build the local community, among others.

Moreover, some sources credit a reputation for a special work ethos as part of a specific mindset to the German Mittelstand (Pahnke and Welter 2019b). This, in turn, would contribute to a very positive connotation of the Mittelstand and the hidden champions: "Due to a number of positive connotations with the term 'Mittelstand' in Germany, even large companies - in which the identity feature of the ownership and management is not present-still perceive themselves as Mittelstand. Therefore, emotions, passion and feelings of belonging, play an important role for understanding the Mittelstand." (Pahnke and Welter 2019b.) This is a very soft characteristic, which is difficult to substantiate or to measure empirically, which is why it was not included in Table 2. What could have inspired the theory on such a specific mindset and its positive connotation? At best, a particular mindset of the Mittelstand that reflects in a particular meticulousness could be elaborated through a socio-historical analysis of the German society in the nineteenth century. There, the roots for the reputation of the Mittelstand may have been laid around a particular mindset, value foundation and work ethos.

Today's Mittelstand is a social class that emerged in the nineteenth century as a result of the industrialization (Sommariva and Tullio 1987). With the rising prosperity and new industrial sectors, a new social class emerged: the bürgertum. The 
semantics of the term Mittelstand thus denotes, on the one hand, a collective term of SMEs that is further characterized by a number of qualitative factors and in addition, it is a sociological term that describes a social class. In this latter meaning, bourgeoisie or bürgertum can be understood as synonyms (Sperber 1997). Although the origins of the German Mittelstand date back to the Middle Ages, the term acquired its current meaning primarily during the Industrial Revolution in Germany. The socio-cultural factors that often describe the mentality of the German Mittelstand in literature could thus be derived from this social change. The historical review of social dynamics, thus allows to make the soft, socio-cultural characteristics of the Mittelstand more tangible and allows to set it on a firmer foundation. Furthermore, such an analysis illustrates how the term Mittelstand gained its positive connotation.

The German industrialization and its transformation from an agrarian to an industrial state formed a new corporate landscape and therewith new jobs in employment relationships (Sommariva and Tullio 1987). This change was driven through, above all, owner-managed SMEs in addition to the few large corporations in the leading sectors of the industrialization, such as the industry of mechanical engineering and automotive (e.g. Benz \& Cie. Rheinische Gasmotorenfabrik, founded in 1883, now known as Daimler $A G$ ), the iron and steel industry (e.g. Krupp-Gussstahlfabrik, 1811, now known as ThyssenKrupp AG), chemistry \& pharmaceuticals (e.g. Badische Anilin- \& Soda-Fabrik, 1865, now known as BASF SE), and electrical engineering (e.g. Deutsche Edison-Gesellschaft für angewandte Elektricität, 1883, now known as $A E G A G$ ). Moreover, since the middle of the nineteenth century, SMEs settled in niches around the great pioneers in the same industries and profited greatly from the progress of the pioneering large corporations, new scientific findings and technological possibilities: in the industry of mechanical engineering and automotive (e.g. HELLA GmbH \& Co. KGaA, 1899), iron and steel (e.g. Otto Fuchs KG, founded in 1910), chemistry \& pharmaceuticals (e.g. Jowat SE, 1919) or electrical engineering (e.g. Kostal GmbH \& Co. Kg, 1912). Most of the hidden champions arose from this peak phase of the industrialization during the Wilhelmine era. To this effect, it's not surprising that most hidden champions operate in the same industries, as mentioned above, that actually were the key industries of the industrialization: mechanical engineering (33.15\%), electrical engineering (10.94\%), automotive $(9.17 \%)$, chemistry \& pharmaceuticals $(5.86 \%)$ and metal ware (4.53\%). Moreover, the sample of 1,372 hidden champions averages the founding year at 1917, which explains how Germany achieved to become the strongest exporting nation behind the USA before the outbreak of World War I. Within only 80 years from the beginning of industrialization, the former agrarian state had become a world economic power, which can be attributed not only to the large corporations but also to the many newly founded and family-run niche market leaders from Germany's Mittelstand.

Until the middle of the nineteenth century, the society in the German Confederation and later the German Empire still resembled a feudal society of classes, which was characterized by the division into clergy (1st class), nobility (2nd class) and peasants along to simple citizens (3rd class) (Veblen 1990). Feudalism provided that feudal lords (nobility and large landowners) granted peasants the right to use their land as vassals in rigid dependence. Along to the industrial revolution, an increasing urbanization, the formation of the class society and the end of the feudal system, a 
new class emerged between the nobility and the lower class (which now was enlarged through the addition of industrial workers): the bürgertum. The political leadership resembled an authoritarian state with a weak parliament, which severely restricted political participation and did not provide liberties for all members of society equally (Weisbrod 1996). While political paternalism had been a tradition for centuries, the industrial revolution and the accompanying educational reforms implied that at least parts of the bürgertum now had the chance to significantly improve their social and economic position through their own efforts. Family businesses were able to accumulate large fortunes, also due to the rapid growth in world trade. The bürgertum, as a social class between the upper class (high clergy and nobility) and the lower class (workers and farmers), was united in its demarcation from the lower class and-especially the possessive bourgeoisie-often adopted aristocratic attitudes and lifestyles of the nobility (building castle-like mansions, use of maids and servants, striving for titles and both military awards and decorations etc.). The decisive factors for the rise of the new society were based on the pillars of private ownership and education in order to sustainably escape the poverty of the lower classes. The liberalization of the industrial regulations and the development of the school and university system (e.g., based on the reforms by von Hardenberg and von Stein) anchored the liberal principle of performance and achievement, and associated values such as diligence, efficiency, and discipline deep in the mindset of the newly emerging bürgertum (Blackbourn 1977). Overcoming the system of guilds, a new kind of entrepreneurship emerged, who could exchange their efforts and knowledge for prosperity and social status. The liberal upper, prosperous and educated bürgertum was united in its desire for German unification and when it took place in 1871, they were valued as loyal subjects of the Wilhelmine Empire, which established the institutional context for a new kind of prosperity (Weisbrod 1996; Torp 2010).

Driven by an aspiration for social advancement and prosperity, the Mittelstand (or bürgertum) diligently drove the economic progress of the Reich and epitomized the new principles of order and efficiency in a new economy of time and profit. In itself, the bourgeois society was divided into the haute bourgeoisie (großbürgertum) and the propertied bürgertum (similar to Marx's concept of bourgeoisie; mainly industrialists and big landowners), the educated bürgertum (professors, senior civil servants) and the petty bürgertum (small merchants, teachers, self-employed craftsmen). Families of the bürgertum placed the highest value on the school education of their children, as it was a guarantee to preserve the privileges of economic progress (Sommariva and Tullio 1987). German industrialization is therefore often linked in literature to the intellectual heritage of a Protestant work ethic, which particularly respected the values of diligence, a sense of order, a sense of duty, punctuality, thrift, determination, and discipline. These values were included in the catalogue of Prussian virtues, which became a foundation of socio-cultural origin of the mindset of the Mittelstand (Weber 1930). 40.6\% of today's German hidden champions were founded before 1918 and emerged from the old family-run craftsmen's firms that settled around the corporations of the booming leading sectors. Over the next few decades, these SMEs grew into medium to large companies forming the largest sub-group of hidden champions. The reputation associated with this social rise may reverberate until the present day. Thus, belonging to the Mittelstand often is 
perceived as an awarding recognition and "[f]or obvious reasons, the Mittelstand is often seen as an exclusively German phenomenon: it has deep roots in the German history; it stands for a specific German variety of capitalism; and it is strongly influenced by previous and current institutional arrangements in Germany" (Pahnke and Welter 2019b). In contrast, the Mittelstand is not limited to Germany and often resembles various forms of everyday entrepreneurship in its many facets (Welter et al. 2017). Yet, the positive connotation of belonging to the Mittelstand is specific to the German Mittelstand and could be due to the historical origin of the Mittelstand in Germany, as explained above. Moreover, the history of the Mittelstand and its bürgertum in Germany is unique, since the foundation of a territorial German state and a coherent economic area took the longest of all Western industrialized countries, as is the late industrialization of the belated nation. It seems likely that the speed and scope of the social rise of the bürgertum has thus particularly shaped the reputation and its positive connotation of the Mittelstand within the German society until the present day.

Furthermore, some sources describe the Mittelstand as innovative (De Massis et al. 2018; Pahnke and Welter 2019b). The characteristic of innovativeness was also not included in the model, as it is questionable whether it applies to the Mittelstand in general. Following the OECD definition, innovation "is the implementation of a new or significantly improved product (good or service), or process, a new marketing method, or a new organizational method in business practices, workplace organization or external relations". Other definitions state that innovation is "...the transformation of knowledge into new products, processes, and services..." (Porter and Stern 1999, p. 12) or that innovation "is a process of turning opportunity into new ideas and of putting these into widely used practice" (Tidd and Bessant 2009, p. 16). Yet, another definition describes that "[i]nnovation=theoretical conception + technical invention + commercial exploitation" (Trott 2012, p. 15). McKinley, Latham and Braun (2014, p. 91) refer innovation to "...any novel product, service, or production process that departs significantly from prior product, service, or production process architectures", while Dosi (1988, p. 222) defines innovation as the "search for, and the discovery, experimentation, development, imitation, and adoption of new products, new production processes and new organizational set-ups." Based on these definitions of innovation, innovation always describes something completely new or substantially developed that changes the widely used practice of a product or process. The spectrum of company types and thus types of innovation in the Mittelstand is enormous and ranges from electricians, painters, or other main street businesses to hidden champions. Is the Mittelstand innovative per se?

The absolute level of innovation varies considerably within this range. To give an example, on the one hand, the Mittelstand comprises most family-owned restaurants and on the other hand, it comprises companies such as Claas (following the IFM Definition), which is an agricultural machinery manufacturer (e.g., producing combine harvesters) and is the market leader within Europe. Of course, this example covers extremes, but it helps to illustrate the heterogeneity within the Mittelstand. Food of Italian restaurants, e.g., are mass-market products and are supposed to replicate the desire of an ideal type, i.e., to fulfil certain expectations of customers, which do not differ fundamentally among consumers and hardly change over time (e.g., the taste of a specific 
Italian dish, no matter if in Dublin or Berlin). At best, an Italian restaurant chef may create his own variety of a certain dish della casa and uses common (or even uncommon) ingredients in a new combination. While this may be somewhat innovative, it is different from innovativeness of products such as combine harvesters after decades of $\mathrm{R} \& \mathrm{D}$. The combine harvester, typical for niche products of the hidden champions, is technically sophisticated, knowledge-intensive and has been fundamentally developed through millions of R\&D investments over the last 150 years. Most restaurant dishes on the other hand, have developed less and has not changed significantly as a product per se. The latter is not a significantly improved product in the sense of the definition of innovation. Although an electrician's individual solution or a painter's special paint can be somewhat innovative, the innovation is less wide-ranging and significant than that of most hidden champions. Additionally, it will rarely change the widely used practice. Therefore, it is questionable, if it is appropriate to speak of innovation in the cases of Italian restaurant dishes, the service of an electrician or a painter. If the significance of change, of novelty, is set as the condition for innovation, one must separate innovation from common value creation. The invention of Italian dishes was an innovation. Yet, not every Italian restaurant chef is innovative, unless there is a significant development of a product or technology in the sense of the definition of innovation.

Of the 3.5 million companies that belong to the German Mittelstand (IFM 2020a, b), only 1372 are hidden champions. Although there are many other very innovative companies in the Mittelstand (in addition to hidden champions), by no means all Mittelstand companies are innovative, which implies that the characteristic rather describes some sub-groups in the Mittelstand as innovative (e.g., start-ups or hidden champions), but not the Mittelstand as such. Key to elaborate whether the Mittelstand can be described as innovative, lies in the choice of which definition is applied for innovation and which for Mittelstand. It is questionable to consider the Mittelstand as innovative per se. When analyzing the Mittelstand, what often actually is referred to, is the subgroup of hidden champions: De Massis et al. (2018) analyze innovation in the Mittelstand and elaborate a number of traits that help Mittelstand companies to innovate successfully despite of limited resources: niche focus and customer collaboration, globalization strategy, preference for self-financing, longrun mindset, superior employee relations, and finally community embeddedness. Using the niche characteristic to describe the Mittelstand and also the following citations that "researchers estimate that there are roughly 1000-1500 Mittelstand firms in Germany" (p. 126), as well as "this article uses the term Mittelstand to identify a German company that is generally small-to-medium in size, is controlled and owned by one family, is a global market player, and identifies itself as a Mittelstand firm" (p. 127), shows that the term Mittelstand here actually refers to the subgroup of hidden champions. Similarly, Pahnke and Welter (2019a, b) argue that the Mittelstand is "by no means less innovative" than Silicon Valley firms. According to them, Mittelstand companies only pursue a different kind of innovation, and explain that "[w]hile Silicon Valley innovations are very consumer-oriented and visible to all of us, Germany's digital and disruptive technologies are first and foremost 'deep tech' hidden in products and processes of other companies" (Pahnke and Welter 2019b). Here, the Mittelstand is explicitly limited to the B2B sector and deep tech. Drawing a conclusion, characterizing the Mittelstand as innovative needs a precise 
understanding of what Mittelstand actually stand for. It is desirable that future research develops a typology for Mittelstand companies, which could include the groups of main street businesses (or everyday entrepreneurship, Welter et al. 2017), world-market leaders and other exporting companies without world-market leadership. Such a typology could, e.g., align along the dimensions of market form, degree of internationalization and innovation activity.

Considering the characteristics of Mittelstand companies, it is apparent still that most of the characteristics seem to apply to hidden champions. The characteristic of identity of ownership and management is taken from the literature on family businesses, and applies to the majority of hidden champions. This suggests some implications for the nature and performance of firms, which will be discussed more in detail in Sect. 5. Regarding the other governance factors, Simon describes that hidden champions use patriarchal leadership and long-term planning horizons. So far, however, only a few hidden champion studies have investigated and confirmed this (Venohr and Meyer 2007).

What concerns the dimension of culture and values, these factors have also been examined only by a few studies. Exceptions are Venohr and Meyer (2007), who identify family culture as a key determinant of the innovative capacity of hidden champions and describe the climate in hidden champions as family-oriented. Moreover, Simon (2009) points out that the leaders of hidden champions are emotionally attached to their companies. This is a characteristic that is also taken from family literature and is typical for family businesses.

With regard to economic key strategies of Mittelstand firms, Simon (2009) has investigated these firm characteristics thoroughly. Besides, a number of other studies have examined these factors conceptually as in relation to hidden champions: economic independence through e.g., Kim (2016) or Lehmann et al. (2019), their nimbleness through Kaudela-Baum et al. (2014) or Lee and Chung (2018). Overall, it can be concluded that the characteristics of Mittelstand research on the nature of Mittelstand firms have been well investigated by literature on hidden champions. Yet, the characteristic of close-customer relations stands out, since Mittelstand firm literature (Welter et al. 2015; Glauser 2016; Audretsch and Lehmann 2016) describes the characteristic more as a phenomenon describing direct local and frequent interaction between firms and customers. Hidden champions are also often characterized by a close-customer relationship, although of a different nature. Hidden champions and their customers are highly interdependent due to the narrow market and few substitutes, and thus co-operate closely, even though customers are distributed worldwide. This suggests that customer loyalty here is based less on emotional and local proximity than on technology dependency.

\section{Hidden champions and research on family firms}

Just as the previous section has classified hidden champions as Mittelstand companies, the majority of hidden champions are family firms. The literature on hidden champions therefore often positions hidden champions in the family firm research (Witt 2015; Lehmann et al. 2019; Audretsch et al. 2019). As an adjacent field of 
research, the delimitation to the field of hidden champions is relevant to identify similarities and differences in the analysis of both fields. For future research, this review would like to draw attention to the fact that much of what has been investigated for hidden champions is already appearing in a similar way within the family firm literature. Examples are the corporate culture of the hidden champions or their leadership strategy (Venohr and Meyer 2007; Walravens and Filipović 2013; Kaudela-Baum et al. 2014). On the other hand, in some areas, hidden champions present anomalies to family firm research. From this differentiation, essential insights can be derived that contribute to describe the nature of hidden champions. Finally, examining hidden champions through the lens of family firm research raises the question as to which extent the concept of familiness influences the performance of hidden champions. The familiness resembles the degree of family involvement and therefore could contribute to explain the nature of hidden champions and contribute to affect their performance (Habbershon et al. 2003). Chrisman et al. (2005, p. 237-238) emphasize in this context, "[t]hat family firms are unique as a result of the involvement of the family through ownership, governance, management, and vision is a basic premise of family business researchers; that these firms behave and, consequently, perform differently is the reason for research; explaining how and why they behave and perform differently is the objective." In order to elaborate on the similarities and differences to hidden champions, the field of family firms is presented to derive its significance for the subgroup of hidden champions. This approach describes a standard principle of family firm research, or as Zellweger et al. (2010, p. 54) put it:"Generally, [family] research has focused on two distinct aspects. First, research has tried to explain differences between family firms and non-family firms (e.g., Chrisman, Steier, \& Chua, 2008)and second, research has focused on variations in behaviors among family firms (e.g., Chrisman et al. 2008) However, all these endeavors are guided by one overarching question: 'How does the family contribute to firm success?" Hidden champions research builds on the latter stream and investigates variations among family firms. Integrating both fields of research is important, because although most hidden champions are family firms, the niche and family character exert contrary effects with regard to innovation and internationalization strategies. The niche and family character present different subsystems that both spur corporate behaviour, similar as how family business research analyses in the dual systems approach (Swartz 1989). The dual systems approach describes "the business and family systems [...] as separate entities in terms of structure, goals, and tasks. The interaction of these two systems has been illustrated by two circles that have varying degrees of overlap" (Whiteside and Brown 1991, p. 383). Research here needs to study, how the familiness impacts hidden champions (when interacting with the niche characteristic) and if it exerts influence on niche firms similarly to mass-market family firms, but its effect is overshadowed by the niche character. This interaction between the familiness and niche effects are aspects for future research, extending the dual systems approach. To integrate the fields of family business and hidden champion research, we need to understand which factors determine the performance of mass-market family firms. This insight will help to conduct performance studies of hidden champions, which are likely to be the subject of largely the same performance variables but may exhibit different manifestations. 
Accordingly, the literature on family firms often reflects an agency cost and benefits approach (Chrisman et al. 2004, 2005) on factors that impact a family firm's performance (ibid.). While the literature on socio-emotional wealth (and therewith associated concepts of nepotism and altruism), risk aversion, social conflicts within the family and minority shareholder expropriation imply negative performance effects, a number of other factors have shown a positive impact on the performance of family firms, such as the emotional attachment to family firms and the associated family awareness and organizational identification, as well as literature on family name implications, family dynasty and tradition.

In addition to purely economic motives, the control of the company's assets provides the incentive to pursue non-economic goals that increase an owner-manager's socioemotional wealth (Gómez-Mejía et al. 2007, 2011; Berrone and Gómez-Mejía 2012). This is carried out despite the fact that the owner has to pay for consumption with his assets, and is thus different from the private benefits of control of a nonowning manager (Barclay and Holderness 1989; Dyck and Zingales 2004; Doidge et al. 2009), who runs the business of someone else. For example, the possibilities of an owner-manager to increase his socio-emotional wealth include: the (1) ability to transfer their firm and family wealth to their offspring (Berrone et al. 2010), the (2) ability to exercise authority over non-family members within the firm (Schulze et al. 2003), the (3) reputation and status within the local community (Deephouse and Jaskiewicz 2013), the (4) continuity and perpetuation of family values and traditions and (5) the status involved, which is granted by the family when the values and expectations of the family are fulfilled (Gómez-Mejía et al. 2007; Berrone et al. 2010), the (6) opportunity to increase one's self-esteem through strong organizational identification with the family business, which also positively influences the self-concept of an owner-manager and his status-attainment (Ashforth and Mael 1989 , 1996), the (7) emotional attachment of family members to the firm (Zellweger and Astrachan 2008), (8) nepotism, i.e. to base hiring and succession decisions on family ties and not solely on competence (Burkart et al. 2003; Jaskiewicz et al. 2013), (9) altruism towards the family (Schulze et al. 2002, 2003). Other topics that have been widely studied in the family business literature include risk aversion and implications of the Buddenbrook effect (Schulze et al. 2001), minority shareholder expropriation (Demsetz and Lehn 1985; Grossman and Hart 1988; Shleifer and Vishny 1997; Burkart et al. 1998; Claessens et al. 1999; La Porta et al. 2000), emotional attachment of owner-managers and employees, which can be divided in awareness, organisational identification and organisational prestige (Deephouse and Jaskiewicz 2013; Bergami and Bagozzi 2000; Ashforth and Mael 1989; Brewer 1979; Dutton et al. 1994; Rousseau 1998; Smidts et al. 2001; Carmeli 2005) and a literature on family firm names and the preservation of the family dynasty and tradition (Deephouse and Jaskiewicz 2013; Dyer and Whetten 2006; Kets de Vries 1993; Van Knippenberg 2000; Zellweger et al. 2011).

The question, which most of these studies investigate, aims at the overall performance effect of family influence. And unfortunately, there are no clear results. Empirical evidence is "mixed and conflicting" (Gómez-Mejía et al. 2011, p. 693). Numerous studies find a positive performance effect of family firms (Anderson and Reeb 2003), and there are also numerous studies, which show that non-family firms 
outperform family firms (Morck et al. 1998; Claessens et al. 2002; Cronqvist and Nilsson 2003; Villalonga and Amit 2006). The different results can be attributed mainly to different definitions, which the authors use to align their sample and their classification of family firms. Furthermore, authors use a whole range of different performance measures (Tobin's Q, Sales Growth, ROA, ROI etc.) which also contribute to the heterogeneity of the results. Above all, the literature review from this section shows how many different effects are present simultaneously and even the same constructs can exhibit either positive or negative effects. Thus, it is clear that family firms are a multidimensional and heterogeneous phenomenon and underlie various performance effects.

The findings of meta-analyses on this topic are ambiguous as well. In a sample of 380 studies, Wagner et al. (2015) find a weak but positive effect of family influence on performance, which is mainly moderated by public and large firms. This means that the effect is significantly stronger for public family firms and large firms. The meta-analysis by Carney et al. (2015) also finds a weak and positive effect of family control on firm performance. In contrast, the meta-analysis by O'Boyle et al. (2012) finds no significant effect that family firms outperform non-family firms. Interestingly, the effects are mainly driven by low R\&D spending and poor international strategies - both of which have a negative impact on firm performance. They conclude that there must be positive agency benefits for family firms on the other side, which compensate for the negative performance effects. And exactly this is another linkage between both fields of research: the internationalization strategy and the innovation and R\&D behaviour of hidden champions and the question of whether both aspects represent an anomaly in the research of family firms. Many research articles on family firms classify family firms as risk-averse (Morck et al. 1998; Schulze et al. 2001; Naldi et al. 2007), thus presenting family firms as less innovative than other firms (Sharma et al. 1997; Zahra 2005) and less internationalized (Zahra 2003; Fernández and Nieto 2005; Graves and Thomas 2008). Since families are very likely to contribute most of their private assets to their own companies, these family assets tend to be diversified inefficiently. This stream of literature concludes that family firms are therefore more risk-averse than other firms. Moreover, family businesses are characterized by a particular emotional attachment to their business which results from a strong organizational identification and the two overlapping reference systems of the family and the business. A failure of the family business thus has more immediate and less separable consequences for a family entrepreneur. When the company fails, this is likely to damage the name of the family, destroy a whole dynasty that often has spanned generations and could cause an economic and personal crisis for other family members such as partners, children and other relatives. This stream of literature thus concludes that family businesses are risk-averse, which ultimately hampers their innovativeness and tendency to internationalize.

Another stream of literature describes family firms as more innovative than non-family firms. This view argues that family firms can build up a rich knowledge base because of their long-term orientation and emulate a higher entrepreneurial spirit than non-family firms (Hall, Melin and Nordqvist 2001; Gudmundson et al. 2003; Rogoff and Heck 2003; Zahra et al. 2004; Zahra 2005; Nordqvist 
et al. 2008; Duran et al. 2016). Zahra (2005) describes that the innovativeness of family firms increases with the number of generations that are involved in the family business. Through long-term, and therefore stable, leadership, the corporate culture can be shaped by the family. Through long-term management, the family can thus create an innovation-friendly culture in the company, which motivates employees to contribute their ideas. The study by Duran et al. (2016) performs a meta-analysis summarizing 108 primary studies from 42 countries to analyse the innovation performance of family and non-family firms. It finds that family firms are more efficient than other firms of similar sizes with regard to their innovativeness. The study points out that most family firms may only have a limited budget for $\mathrm{R} \& \mathrm{D}$, but overall are more innovative than other non-family firms measured by the number of new products, revenues of new products and the number of patents. The authors conclude that family firms are more efficient processing innovation. They argue that family ownership, as a large shareholding, succeeds better in monitoring the investments of managers. Family control therefore assures a long-term strategy, which is essential to implement innovation strategies. This insight also echoes in the second important finding of the study that describes older family firm generations to gain more innovation output from less input. Founders tend to invest more in innovation but achieve significantly lower outputs of innovation. They argue that later generation benefit from long-term customer relationships, gained product and industry knowledge and better achieve to select fruitful ideas to develop their products.

Integrating these insights from the family firm literature with the literature review on hidden champions, allows us to disentangle some of the determinants of the hidden champions' performance. Hidden champions are very innovative companies in terms of their R\&D behaviour and patent numbers. Thus, they rather fit into the latter stream of the family firm literature (Kaudela-Baum et al. 2014), although, they differ from this stream with regard to their niche approach. Research on the innovation strategy of hidden champions shows that the niche characteristic and the resulting specialisation and focus are the main drivers to determine the innovativeness of hidden champions. Thus, hidden champions are an exception of innovative and (mostly) family-owned companies and have to be examined primarily by means of a niche market strategy. Similarly, the riskaversion and emotional attachment to a family business is reported to impede the internationalization efforts of family firms. Again, this review concludes that the niche strategy is key to explain why hidden champions, unlike other family firms, place internationalization at the forefront of their strategy. Overall, it is important to underline that both factors essentially determine the performance of hidden champions and must be included alongside the influence of the familiness in order to examine the drivers (and possible interaction effects) of the hidden champions' performance (Habbershon et al. 2003). To date, there are only a few studies that have investigated the hidden champions' performance empirically before, and thus will be of interest in future research on hidden champions (Benz et al. 2020). 


\section{Conclusion}

This article is a literature review of the research field of hidden champions. Key findings from the hidden champions literature were summarized to distinguish different strands of literature within the field of hidden champions and finally to classify the field of hidden champions into its adjacent and superordinate fields of Mittelstand and family business research. To do so, this review discussed findings from research on the Mittelstand and family businesses regarding their implications for hidden champions. Building on these insights, a number of avenues for future research emerge.

Yet, some limitations arise of this article such as a sampling and survivorship bias. A sampling bias occurs when a sample of a population is collected in such a way that not all cases have the same probability of being included in the sample. This could result in distorted samples that are not completely randomised and thus possibly lead to false conclusions about the population. The analysis of hidden champions is based on various data literature has compiled. Each sample of hidden champions aims at including world-market leaders of a certain country or region. Still, it cannot be ruled out that some cases are missing. Especially, local knowledge about resident companies influences the underlying sample of hidden champions. Moreover, previous knowledge regarding different industries can lead to the fact that some world-market leaders were not selected. This holds especially for bottom-up sampling. Closely related to this, world-market leadership per se is a criterion based on the companies' self-assessment. Since there is no worldwide database and market survey on niche markets, this self-assessment of the companies is not entirely reliable. Market shares are at best estimated, and niches are sometimes defined too narrowly, as companies sometimes aim at adorning themselves with the title of being a world-market leader without being able to prove this objectively. After all, samples of hidden champions are subject to a survivorship bias. Companies, which no longer exist might have contributed to shape the phenomenon of hidden champions, but are no longer present within the samples, as they are either insolvent or have been acquired by other companies. Therefore, they are missing in the analysis. Finally, this review is limited to the articles it incorporates. A full coverage of all scholarly researched articles on hidden champions was attempted, but cannot be guaranteed.

Besides the ideas for future research that have been outlined in Sect. 4 and 5, a number of further future research avenues arise for the scientific community. Future research is mandated to explore the determinants of management succession of hidden champions. Especially, in light of the demographic developments and the possible negative consequences of the latest inheritance tax reform in Germany, the intergenerational succession of hidden champions will become an ever more difficult challenge within the families. Similarly, a failed succession increases the likelihood of hidden champions to become a target for M\&As. Firm survival thus could likely depend on the long-term commitment of investors.

Another starting point for the topic of management succession revolves around the concepts of emotional ownership and organizational prestige (Cialdini et al. 
1976). Venohr and Meyer (2007, p. 11) state in this context that the owners of hidden champions are often "emotionally attached to their firm, which is typically an integral part of their self-fulfillment and the family tradition, rather than 'just' a financial investment. Their raison d'être is thus not only to maximize profits but to secure the company's existence for the next generations. Firms are designed to stay independent and to achieve multigenerational continuity". The willingness of the successors to take over the company should be higher than in other family businesses, which might be explained through the organizational prestige hidden champions bestow. Organizational prestige refers to one's own beliefs about how other people outside the organization such as customers or suppliers "judge or evaluate the status and prestige of the organization" (Carmeli 2005 , p. 444). The prestige is determined primarily through the global market leadership, the monopoly position, the global market reach, and the high standard of a hidden champion's specialized and technological products. In addition, both the high employee loyalty and organizational identification of the employees is likely to increase the prestige that it is associated with succession within a hidden champion. The other explanatory factor to be tested with regard to the probability of the hidden champions' management succession is also based on the concept of organisational identification. Björnberg and Nicholson (2012) describe the concept of emotional ownership as "a cognitive and affective state of association that describes a (young) family member's attachment to and identification with his or her family" (Nicholson and Björnberg 2008, p. 32). This illustrates why potential successors often consider the continuity of the family dynasty as an inner sense of duty. The affection for the tradition and legacy of the family business motivates them to preserve the family dynasty and thus act as "stewards of the family" (Graves and Thomas 2008, p. 163). A further aspect of this stream of future research examines the career choice decisions of university graduates. According to my dataset, $70.4 \%$ of the German hidden champions are located in rural areas. In order to study at universities, the children of the hidden champions' families often leave their homes for cities, where universities commonly are located. Against this backdrop, the social attachment to a graduate's home area, the regional identity, social embeddedness, quality of life, amenities alongside the urban-rural continuum and the spatial distance to the place of study altogether are likely to determine the probability of succession. It is important to note that the relevance of this topic emerges through the rural spread of hidden champions, their prestigious nature, and the graduate career decisions of their offspring, which altogether warrants investigation.

Moreover, future research should analyse the often-cited niche market firm's characteristic of being hidden. Simon (2009) describes that the hiddenness serves a success factor for hidden champions and resembles a low brand awareness of their products and services. The more hidden they are, the less they inspire other companies to challenge their monopolistic position in the niche. Here, Simon's characteristic of low public awareness serves as the third major factor in his widely accepted definition of hidden champions. A shortcoming of research on hidden champions has been that this has not been measured empirically so far. Lending from the literature on brand equity and brand awareness (Coulter et al. 2012), this article finally 
Table 4 Top fifteen Niche Brand Awareness Index. source: own computation; note: The high ranking for Syntegon Technology GmbH (formerly Bosch Packaging Technology), BASF Schwarzheide GmbH and Bosch Industriekessel GmbH might be a result of a Robert Bosch GmbH and BASF SE brand spillover

\begin{tabular}{|c|c|c|c|}
\hline Rank & Logo & Hidden Champion & $\begin{array}{c}\text { Niche Brand } \\
\text { Awareness Index }\end{array}$ \\
\hline 1 & गाला? & Puma SE & 100 \\
\hline 2 & BRAUn & Braun GmbH & 41.5 \\
\hline 3 & BOSS & HUGO BOSS AG & 32.8 \\
\hline 4 & $\underset{\text { Processiva \& AACKAGANa }}{\text { SYNTEG }}$ & Syntegon Technology GmbH & 25.0 \\
\hline 5 & (2) STABILO & STABILO International GmbH & 16.7 \\
\hline 6 & STIHL & STIHL HOLDING & 16.2 \\
\hline 7 & FABER-CASTELL & Faber-Castell AG & 15.7 \\
\hline 8 & $\begin{array}{l}\text { W } \\
\text { We create chemisfry }\end{array}$ & BASF Schwarzheide GmbH & 14.5 \\
\hline 9 & (1D) $\underset{\text { Techniki tirs seben }}{\mathbf{B O S C H}}$ & Bosch Industriekessel GmbH & 12.9 \\
\hline 10 & (îl|IV $\begin{array}{l}\text { Boehringer } \\
\text { Ingelheim }\end{array}$ & $\begin{array}{l}\text { Boehringer Ingelheim AG \& } \\
\text { Co. KG }\end{array}$ & 12.3 \\
\hline 11 & D SENNHEISER & $\begin{array}{l}\text { Sennheiser Electronic GmbH \& } \\
\text { Co. KG }\end{array}$ & 10.2 \\
\hline 12 & WKARCHER & Alfred Kärcher GmbH & 9.4 \\
\hline 13 & $\begin{array}{l}\text { MONT } \\
\text { BLANC }\end{array}$ & Montblanc International $\mathrm{GmbH}$ & 8.0 \\
\hline 14 & $\begin{array}{l}\text { Schneider } \\
\text { OElectric }\end{array}$ & Schneider GmbH Co KG & 7.6 \\
\hline 15 & HARIBO & $\begin{array}{l}\text { Haribo Holding GmbH \& Co. } \\
\text { KG }\end{array}$ & 6.1 \\
\hline
\end{tabular}

presents a first landmark to introduce such an index measuring niche brand awareness (Tables 4, 5). Based on that, samples of hidden champions could be revised and the definition for hidden champions refined. The concept of hidden champion could gain in clarity, once firms are excluded from hidden champions samples that actually are rather non-hidden and thus well-known to the public. While the index could be applied to test the influence of brand awareness on the performance of hidden champions, the determinants of hidden and non-hidden champions could be disentangled (such as industry/consumer markets, the competitiveness of the niche market, 
Table 5 Top fifteen B2B Niche Brand Awareness Index. source: own computation

\begin{tabular}{|c|c|c|c|}
\hline Rank & Logo & Hidden Champion & $\begin{array}{c}\text { Niche Brand } \\
\text { Awareness Index }\end{array}$ \\
\hline 1 & $\underset{\text { PROCESIIIG \& PACKGING }}{\text { SYNT }}$ & Syntegon Technology GmbH & 25.0 \\
\hline 2 & $\begin{array}{l}\text { - BASF } \\
\text { we create chemistry }\end{array}$ & BASF Schwarzheide GmbH & 14.5 \\
\hline 3 & (iAD) $\underset{\text { Technik tirs Leten }}{\text { BOSCH }}$ & Bosch Industriekessel GmbH & 12.9 \\
\hline 4 & (, $\left.\hat{\|}_{11}\right) \begin{array}{l}\text { Boehringer } \\
\text { Ingelheim }\end{array}$ & $\begin{array}{l}\text { Boehringer Ingelheim AG \& } \\
\text { Co. KG }\end{array}$ & 12.3 \\
\hline 5 & $\begin{array}{l}\text { Schneider } \\
\text { REElectric }\end{array}$ & Schneider GmbH Co KG & 7.6 \\
\hline 6 & Dråger & Drägerwerk AG & 4.6 \\
\hline 7 & 새남 & Hella KGaA Hueck \& Co. & 4.4 \\
\hline 8 & $\stackrel{\text { GROHE }}{\cong}$ & Grohe AG & 4.4 \\
\hline 9 & $\bigotimes_{\text {thyssenkrupp }}$ & $\begin{array}{l}\text { Thyssen Krupp Marine } \\
\text { Systems GmbH }\end{array}$ & 4.0 \\
\hline 10 & CLATE & CLAAS KGaA & 3.1 \\
\hline 11 & تGOLDBECK & Goldbeck GmbH & 3.1 \\
\hline 12 & L14 & Heckler und Koch GmbH & 3.0 \\
\hline 13 & IIAHLE ${ }^{\circ}$ & Mahle GmbH & 3.0 \\
\hline 14 & Excelence in Mechatronics & $\begin{array}{l}\text { Brose Fahrzeugteile GmbH \& } \\
\text { Co. KG }\end{array}$ & 2.9 \\
\hline 15 & มเตा & ThyssenKrupp Bilstein GmbH & 2.8 \\
\hline
\end{tabular}

employer branding efforts or investor relations of publicly listed hidden champions). The Niche Brand Awareness Index is a composite index that uses online media metrics to measure the hidden champions' digital visibility. The five items used for index computation are the number of LinkedIn followers, the number of Facebook likes, the number of Wikipedia page views and both the number of Kununu page views and reviews. Scoring a Cronbach's Alpha of 0.652, the newly introduced index underlines its high reliability. While Table 4 illustrates the top 15 of the overall index ranking, Table 5 shows the top 15 ranking for industry-to-industry markets. Puma SE serves as the base level (=1), standing out as the (non-) hidden champion 
with the strongest niche brand awareness. The results indicate that some Hidden Champions indeed emulate a strong brand awareness, such as Puma, Braun or Hugo Boss. Future research could build thereon and disentangle the determinants of hidden and non-hidden niche brands.

Authors' contributions I declare that I am the only contributing author of this submission.

Funding Open Access funding enabled and organized by Projekt DEAL.

Data availability Availability of data is given.

\section{Declarations}

Conflict of interest The author has no financial or non-financial interests to disclose.

Open Access This article is licensed under a Creative Commons Attribution 4.0 International License, which permits use, sharing, adaptation, distribution and reproduction in any medium or format, as long as you give appropriate credit to the original author(s) and the source, provide a link to the Creative Commons licence, and indicate if changes were made. The images or other third party material in this article are included in the article's Creative Commons licence, unless indicated otherwise in a credit line to the material. If material is not included in the article's Creative Commons licence and your intended use is not permitted by statutory regulation or exceeds the permitted use, you will need to obtain permission directly from the copyright holder. To view a copy of this licence, visit http://creativecommons.org/licen ses/by/4.0/.

\section{References}

Acs Z, Audretsch DB (1989) Patents as a measure of innovative activity. Kyklos 42(2):171-180

Acemoglu D, Griffith R, Aghion P, Zilibotti F (2010) Vertical integration and technology: theory and evidence. J European Economic Associat 8(5):989-1033

Adenäuer C (2007) Erfolgsunternehmen in der Industrie-Analyse von Einflussfaktoren auf Grundlage des BDI-Mittelstandspanels. In Jahrbuch zur Mittelstandsforschung, 1/2007 (15-47). Gabler, Wiesbaden, Germany

Antràs P, Chor D (2013) Organizing the global value chain. Econometrica 81(6):2127-2204

Anderson R, Reeb D (2003) Founding-family ownership and firm performance: evidence from the S\&P 500. J Finance 58(3):1301-1328

Audretsch DB (2019) Have we oversold the silicon valley model of entrepreneurship? Small Bus Econ. 56:1-8

Audretsch DB, Lehmann E (2016) The seven secrets of Germany: Economic resilience in an era of global turbulence. Oxford University Press, New York, NY, US

Audretsch DB, Lehmann EE, Schenkenhofer J (2018) Internationalization strategies of hidden champions: lessons from Germany. Multinatl Bus Rev 26(1):2-24

Audretsch DB, Lehmann EE, Schenkenhofer J (2021) A context-choice model of niche entrepreneurship. Entrep Theory Pract 45(5):1276-1303

Baloh P (2013) Innovation Behaviour of Hidden Champions. Hidden Champions in CEE and Turkey: Carving Out a Global Niche. Springer, Berlin, Heidelberg, pp 53-67

Barclay MJ, Holderness CG (1989) Private benefits from control of public corporations. J Finance Econ 25(2):371-395

Bennedsen M, Nielsen KM, Pérez-González F, Wolfenzon D (2007) Inside the family firm: the role of families in succession decisions and performance. Q J Econ 122(2):647-691 
Benz L, Block J, Johann M (2020) Börsennotierte Hidden Champions. Zfo - Zeitschrift Führung Und Organisation 5:291-295

Benz L, Block J, Johann M (2021) Hidden champions as a determinant of regional development: an analysis of German districts. Zeitschrift Für Wirtschaftsgeographie. https://doi.org/10.1515/ zfw-2020-0043

Bergami M, Bagozzi P (2000) Self-categorization, affective commitment and group self-esteem as distinct aspects of social identity in the organization. British J Soc Psychol 39(4):555-577

Berghoff H (2006) The end of family business? The Mittelstand and German capitalism in transition, 1949-2000. Bus Hist Rev 80(2):263-295

Berrone P, Cruz C, Gomez-Mejia LR, Larraza-Kintana M (2010) Socioemotional wealth and corporate responses to institutional pressures: do family-controlled firms pollute less? Adm Sci Q 55(1):82-113

Berrone P, Cruz C, Gomez-Mejia LR (2012) Socioemotional wealth in family firms: theoretical dimensions, assessment approaches, and agenda for future research. Fam Bus Rev 25(3):258-279

Björnberg $\AA$, Nicholson N (2012) Emotional ownership: the next generation's relationship with the family firm. Fam Bus Rev 25(4):374-390

Blackbourn D (1977) The Mittelstand in German society and politics, 1871-1914. Soc Hist 2(4):409-433

Blackburn J, Merrilees B, Tiessen J, Lindman M (2001, December) Hidden (SME) champions: the role of innovation and strategy. In: proceedings of the Australian and New Zealand marketing academy conference, pp 1-5

Block J (2019) Rural entrepreneurship: between start-ups, hidden champions and family businesses. J Bus Econ Sustain Leadership Innov 3:14-19

Block J (2020) Der (unheimliche) Erfolg des Begriffs "Hidden Champion.” Zfo - Zeitschrift Führung Und Organisation 5:311

Block J, Moritz A, Benz L (2021) Johann M (2021) Hidden Champions in Rheinland-Pfalz: Identifikation, Erfolgsfaktoren. University of Trier, Herausforderungen. Study of the research center Mittelstand

Block J (2015) Unternehmertum auf dem Land: Gründungen, Hidden Champions und Familienunternehmen. In: H. Arend, G. Troeger-Weiß (eds), Starke Wirtschaft - Starke Regionen. Gute Aussichten für das Land. ZIRP, Mainz, pp 49-52

Bowlby J (1979) The making and breaking of affectional bonds. Tavistock, London, UK

Brewer MB (1979) In-group bias in the minimal intergroup situation: a cognitive motivational analysis. Psychol Bull 86:307-324

Brkic N, Berberovic D (2013a) International Marketing. Hidden Champions in CEE and Turkey: Carving Out a Global Niche. Springer, Berlin, Heidelberg, pp 69-79

Brkic N, Berberovic D (2013b) Hidden Champions of Bosnia and Herzegovina. Hidden Champions in CEE and Turkey: Carving Out a Global Niche. Springer, Berlin, Heidelberg, pp 141-162

Brynjolfsson E (1994) Information assets, technology and organization. Manag Sci 40(12):1645-1662

Büchler JP (2017) Fallstudienkompendium Hidden Champions: Innovationen für den Weltmarkt. Springer, Wiesbaden, Germany

Burkart M, Gromb D, Panunzi F (1998) Why higher takeover premia protect minority shareholders. J Polit Econ 106(1):172-204

Burkart M, Panunzi F, Shleifer A (2003) Family firms. J. Finance 58(5):2167-2201

Buse S Tiwari R (2014) Global innovation strategies of German hidden champions in key emerging markets. Working Paper 85 Hamburg University of Technology

Cabrera-Suárez MK, Déniz-Déniz MD, Martín-Santana JD (2014) The setting of non-financial goals in the family firm: The influence of family climate and identification. J Fam Bus Strateg 5(3):289-299

Carmeli A (2005) Perceived external prestige, affective commitment, and citizenship behaviors. Organ Studies 26(3):443-464

Carney M, Van Essen M, Gedajlovic ER, Heugens PP (2015) What do we know about private family firms? A Meta-Analy Rev Entrepr Theor Pract 39(3):513-544

Carroll AB (1998) The four faces of corporate citizenship. Bus Soc Rev 100(1):1-7

Çetindamar D, Kozanoglu H (2012) Competitiveness of Turkish hidden champions. In: proceedings of PICMET'12: technology management for emerging technologies, pp 2072-2077

Chang HJ, Ko YH (2014) An analysis of key success factors of hidden champions in Korea: case study focusing on IT industry (in Korean). Int Bus Rev 18(2):25-56

Chrisman JJ, Chua JH, Litz RA (2004) Comparing the agency costs of family and non-family firms: conceptual issues and exploratory evidence. Entrepr Theory Pract 28(4):335-354 
Chrisman JJ, Chua JH, Sharma P (2005) Trends and directions in the development of a strategic management theory of the family firm. Entrepr Theory Pract 29(5):555-575

Chrisman JJ, Steier LP, Chua JH (2008) Toward a theoretical basis for understanding the dynamics of strategic performance in family firms. Entrep Theory Pract 32(6):935-947

Cialdini RB, Borden RJ, Thorne A, Walker MR, Freeman S, Sloan LR (1976) Basking in reflected glory: three (football) field studies. J Pers Soc Psychol 34(3):366-375

Claessens S, Djankov S, Fan JP, Lang LH (2002) Disentangling the incentive and entrenchment effects of large shareholdings. J Finance 57(6):2741-2771

Claessens S, Fan, J P, Djankov S, Lang L H (1999) On expropriation of minority shareholders: evidence from East Asia. Available at SSRN 202390

Coase RH (1937) The nature of the firm. Economica 4(16):386-405

Cooper HM (1988) Organizing knowledge synthesis: a taxonomy of literature reviews. Knowl Soc 1(1):104-126

Coulter KS, Gummerus J, Liljander V, Weman E, Pihlström M (2012) Customer engagement in a Facebook brand community. Manag Res Rev 35(9):857-877

Cronqvist H, Nilsson M (2003) Agency costs of controlling minority shareholders. J Financ Quant Anal 38(4):695-719

Dalgic T, Leeuw M (1994) Niche marketing revisited: concept, applications and some European cases. Eur J Mark 28(4):39-55

Daneyko P, Golenchenko P (2013) Hidden Champions of Belarus. Hidden Champions in CEE and Turkey: Carving Out a Global Niche. Springer, Berlin, Heidelberg, pp 127-140

De Massis A, Audretsch D, Uhlaner L, Kammerlander N (2018) Innovation with limited resources: management lessons from the German Mittelstand. J Prod Innov Manag 35(1):125-146

Deephouse DL, Jaskiewicz P (2013) Do family firms have better reputations than non-family firms? An integration of socioemotional wealth and social identity theories. J Manag Stud 50(3):337-360

Demsetz H (1988) The theory of the firm revisisted. J Econ Organ 4(1):141

Demsetz H, Lehn K (1985) The structure of corporate ownership: causes and consequences. J Polit Econ 93(6):1155-1177

Deng D, Wan Z (2006) Focus on Understanding of Chinese Hidden Champions. Zhekiang University Press, Hangzhou, China

Depalov VR, Todorović M, Marinković S (2013) Hidden Champions of Serbia. Hidden Champions in CEE and Turkey. Springer, Berlin, Heidelberg, pp 307-330

Din FU, Dolles H, Middel R (2013) Strategies for small and medium-sized enterprises to compete successfully on the world market: cases of Swedish hidden champions. Asian Bus Manag 12(5):591-612

Ding K (2008) How to become successful Hidden Champions: Case Study of Japanese SMEs. Bus Frontier 27(1)

Doidge C, Karolyi GA, Lins KV, Miller DP, Stulz RM (2009) Private benefits of control, ownership, and the cross-listing decision. J Finance 64(1):425-466

Doppelmayr (2019) Kundenzeitschriften. Jahrbuch 2019, p. 110. Retrieved from https://newsroom.doppe lmayr.com/de/doppelmayr/all/ (accessed 03/04/2020)

Duran, P, Kammerlander, N, Van Essen, M, \& Zellweger, T (2016) Doing more with less: Innovation input and output in family firms. Academy Manag J:59(4), 1224-1264

Dutton JE, Dukerich JM, Harquail CV (1994) Organizational images and member identification. Adm Sci Q 39:239-263

Dyck A, Zingales L (2004) Private benefits of control: an international comparison. J Finance 59(2):537-600

Dyer WG Jr, Whetten DA (2006) Family firms and social responsibility: preliminary evidence from the S\&P 500. Entrepr Theory Pract 30(6):785-802

Eisenhardt KM (1989) Agency theory: an assessment and review. Academy Manag Rev 14(1):57-74

Fernández Z, Nieto MJ (2005) Internationalization strategy of small and medium-sized family businesses: some influential factors. Fam Bus Rev 18(1):77-89

Fryges H (2006) Hidden champions-how young and small technology-oriented firms can attain high export-sales ratios ZEW-Centre for European Economic Research Discussion Paper:6-45

Gabbott M (2004) Undertaking a literature review in marketing. Mark Rev 4(4):411-429

Garaus C, Güttel WH, Konlechner S, Koprax I, Lackner H, Link K, Müller B (2016) Bridging knowledge in ambidextrous HRM systems: empirical evidence from hidden champions. Int $\mathrm{J}$ Hum Resour Manag 27(3):355-381 
Glauser M (2016) Main Street Entrepreneur: Build Your Dream Company Doing what You Love where You Live. Entrepreneur Press, Irvine, California, US

Gómez-Mejía LR, Haynes KT, Núñez-Nickel M, Jacobson KJ, Moyano-Fuentes J (2007) Socioemotional wealth and business risks in family-controlled firms: evidence from Spanish olive oil mills. Adm Sci Q 52(1):106-137

Gómez-Mejía LR, Cruz C, Berrone P, De Castro J (2011) The bind that ties: Socioemotional wealth preservation in family firms. Academy Manag Annals 5(1):653-707

Graves C, Thomas J (2008) Determinants of the internationalization pathways of family firms: an examination of family influence Fam. Bus Rev 21(2):151-167

Grossman SJ, Hart OD (1986) The costs and benefits of ownership: a theory of vertical and lateral integration. J of Polit Econ 94(4):691-719

Grossman SJ, Hart OD (1988) One share-one vote and the market for corporate control. J Financ Econ 20:175-202

Gudmundson D, Tower CB, Hartman EA (2003) Innovation in small businesses: culture and ownership structure do matter. J Dev Entrepr 8(1):1-17

Hart O, Moore J (1990) Property rights and the nature of the firm. J Polit Econ 98(6):1119-1158

Hart O, Moore J (2005) On the design of hierarchies: coordination versus specialization. J Polit Econ 113(4):675-702

Hart C (2018) Doing a literature review: Releasing the research imagination Sage, London, UK

Habbershon TG, Williams M, MacMillan IC (2003) A unified systems perspective of family firm performance. J BusVentur 18(4):451-465

Haussmann H (2003) Spezifische Erfolgsfaktoren von hidden-champions im Internationalisierungsprozess. Management Multinationaler Unternehmungen. Physica, Heidelberg, pp 105-120

Herstatt C, Tiwari R, Buse S (2017) Innovating for emerging markets? An assessment of German hidden champions' strategies. Technologie. Strategie und Organisation. Springer Gabler, Wiesbaden, pp 219-238

Holmström BR, Tirole J (1989) The theory of the firm. Handbook of Ind Org 1:61-133

Huh MG (2015) Characteristics and technology development mode of local hidden champions in Korea: how are they different? J Digit Convergence 13(8):221-234

IFM (2019) Institut für Mittelstandsforschung Bonn Retrieved from https://wwwifm-bonn.org/definition en/mittelstandsdefinition-des-ifm-bonn/ (accessed 12/12/2019)

IFM (2020a) Institut für Mittelstandsforschung Bonn Retrieved from https://wwwifm-bonn.org/home/ newsdetail/?txifmstudiesnewsdetail $\% 5$ Bnews $\% 5 \mathrm{D}=644 \& \mathrm{cHash}=537 \mathrm{e} 22 \mathrm{ef} 94 \mathrm{c} 66 \mathrm{ce} 42 \mathrm{e} 6 \mathrm{dcf} 868$ c4ddb0c/ (accessed 02/04/2020)

IFM (2020b) Institut für Mittelstandsforschung Bonn Retrieved from https://wwwifm-bonn.org/definition en/kmu-definition-des-ifm-bonn/ (accessed 04/04/2020)

Jaskiewicz P, Uhlenbruck K, Balkin DB, Reay T (2013) Is nepotism good or bad? Types of nepotism and implications for knowledge management. Fam Bus Rev 26(2):121-139

Jensen MC, Meckling WH (1976) Theory of the firm: Managerial Behavior, agency costs, and ownership structure. Economics Social Institutions. Springer, Dordrecht, pp 163-231

Jungwirth G (2017) Die Unternehmenskultur von familiengeführten österreichischen Hidden Champions. Working Paper, FH Campus 02, Graz, Austria

Kamp B (2018) Expanding international business via smart services: insights from 'hidden champions' in the machine tool industry. Int Bus Inf Digit Age 13:273-293

Kamp B (2019) Assessing the economic relevance of International Niche market leaders: empirical indicators and strategic reflections from the Basque Country. Ekon Rev Vasca Econ 95(1):229-253

Kaudela-Baum S, Kocher PY, Scherrer S (2014) Innovationen fördern Die Gestaltung von Freiräumen als Führungsaufgabe von Hidden Champions. Zeitschrift Für Führung Und Organisation 2:74-79

Kim SW (2010) An analysis of critical factors in the success of global 'hidden champion' enterprises. Korean Ventur Manag Rev 13(1):87-114

Kim MK, Park JH (2015) Growth factors and promotion directions for global hidden champions in Korean ICT SMEs. Electron Telecommun Trends 30(2):79-86

Kim YG, Suh J (2015) What determines small champions' export performance? Evidence from Korea firm-level data. Asian Econ Pap 14(2):138-155

Kim D, Sung SH (2019) An analysis on the growth factors and organizational performance of small giant enterprises. South Korea Product Rev 33(3):69-95

Kim W (2016) Structural features and mechanisms of the Korean powerhouses: what makes these niche companies leaders in the global market? J Econ Polit Econ 3(2):284-308 
Kirner E, Zenker A (2011) Are knowledge angels the secret behind the success of hidden champions and hidden innovators. EvoREG Research Note 15:1-7

Kume V, Kume A (2013) Hidden Champions of Albania. Hidden Champions in CEE and Turkey: Carving Out a Global Niche. Springer, Berlin, Heidelberg, pp 109-126

La Porta R, Lopez-de-Silanes F, Shleifer A, Vishny R (2000) Investor protection and corporate governance. J Financ Econ 58(1-2):3-27

Lahti A (2014) International trade, entrepreneurship, and monopolistic competition: German hidden champions and global markets. China-USA Bus Rev 13(9):592-613

Landau C, Karna A, Täube F (2016) The internationalization of hidden champions: setting the context for advancing research on emerging market strategies for German Mittelstand firms. In: Handbook of Contemporary Research on Emerging Markets. Edward Elgar Publishing

Lang T, Görmar F, Graffenberger M, Vonnahme L (2019) Hidden Champions und Stadtentwicklung: die wirtschaftliche und gesellschaftliche Bedeutung innovativer Unternehmen für Kleinstädte in peripherer Lage. Bundesamt für Bauwesen und Raumordnung

Langenscheidt F, Venohr B (2015) Lexikon der deutschen Weltmarktführer. Gabal Verlag, Offenbach am Main

Lebedev P (2013) Financial Aspects of HCs Business Models. Hidden Champions in CEE and Turkey: Carving Out a Global Niche. Springer, Berlin, Heidelberg, pp 95-107

Lee JW (2009) The exploration of new business areas in the age of economic transformation: 'a case of Korean hidden champion' (small and medium niche enterprises). Korean Small Bus Rev 31(1):73-88

Lee SS (2016a) A comparison of weight on SWOT factors of hidden champion between Korea and Germany. Asia-Pacific J Bus Ventur Entrepr 11(6):163-174

Lee SS (2016b) A study on entrepreneurship, competitiveness of SWOT, and performance in hidden champion firm. Asia-Pacific J Bus Ventur Entrepr 11(2):21-33

Lee SS, Chung YK (2018) A study on development strategy of Korean hidden champion firm: focus on SWOT/AHP technique utilizing the competitiveness index. J Int Entrepr 16(4):547-575

Lee HB, Yang DW (2020) Analysis on the patent portfolio for hidden champion companies: focusing on the "hidden champion" companies introduced in herman simon's book. J Korea Converg Soc 11(7):259-272

Lee YJ, Yoon DJ (2015) The capabilities needed for becoming a global hidden champion. Int Bus Rev 26(2):33-61

Lee BH, Lee SM, Han JH (2010) The hidden champion of top-notch high-tech manufacturers in korea: the growth and globalization efforts of jusung engineering Co. Korean Academy Int Bus. 14(1): $125-150$

Lehmann EE, Schenkenhofer J, Wirsching K (2019) Hidden champions and unicorns: a question of the context of human capital investment. Small Bus Econ 52(2):359-374

Lei L, Wu X (2020) Thinking like a specialist or a generalist? Evidence from hidden champions in China. Asian Bus Manag. Doi: https://doi.org/10.1057/s41291-020-00114-2

Li Q H, Li C S (2008) On hidden champion enterprises: Strategic logic, business model and critical success factors. J Southeast University (Philosophy Soc Sci) 6(10)

Matten D, Crane A (2005) Corporate citizenship: toward an extended theoretical conceptualization. Academy Manag Review 30(1):166-179

McEachern WA (2011) Economics: A contemporary introduction. Cengage Learning, Mason, USA

McKiernan P, Purg D (2013a) Hidden champions in CEE and Turkey: Carving Out a Global Niche. Springer, Berlin, Heidelberg

McKiernan P, Purg D (2013b) The Context of Hidden Champions. Hidden Champions in CEE and Turkey: Carving Out a Global Niche. Springer, Berlin, Heidelberg, pp 1-7

Mear F, Werner RA (2021) Subsidiarity as secret of success: "Hidden Champion" SMEs and subsidiarity as winning HRM configuration in interdisciplinary case studies". Empl Relat 43(2):524-554

Meffert J, Klein H (2007) DNS der Weltmarktführer: Erfolgsformeln aus dem Mittelstand A McKinsey Survey of Germany Hidden Champions between 1998 and 2003 Redline Wirtschaft: Heidelberg

Müller C (2016) Umfrage Weltmarktführerindex. Research study, St. Gallen

Muñoz EP, Ripoll-i-Alcon J, Silvente VB (2017) Hidden champions in Spain: the path to successful business decisions. Revista De Métodos Cuantitativos Para La Economía y La Empresa 24:190-208

Naldi L, Nordqvist M, Sjöberg K, Wiklund J (2007) Entrepreneurial orientation, risk taking, and performance in family firms. Fam Bus Rev 20(1):33-47 
Nicholson N, Björnberg $\AA$ (2008) The shape of things to come-Emotional ownership and the next generation in the family firm. In: Tapies J, Ward J (eds) Family values and value creation. The fostering of enduring values within family-owned businesses. Palgrave Macmillan, London, pp 29-52

Nordqvist M, Habbershon TG, Melin L (2008) Transgenerational entrepreneurship: Exploring entrepreneurial orientation in family firms. In: Landström D, Smallbone D, Crijns H, Laversen E (eds) Entrepreneurship, Sustainable Growth and Performance: Frontiers in European Entrepreneurship Research. Edward Elgar, London, UK, pp 93-116

Nummela N, Saarenketo S, Puumalainen K (2004) A global mindset-a prerequisite for successful Internationalization? Canadian J Adm Sci 21(1):51-64

O'Boyle EH Jr, Pollack JM, Rutherford MW (2012) Exploring the relation between family involvement and firms' financial performance: a meta-analysis of main and moderator effects. J Bus Ventur 27(1): $1-18$

Omazić MA, Vlahov RD (2013) Hidden Champions of Croatia. Hidden Champions in CEE and Turkey: Carving Out a Global Niche. Springer, Berlin, Heidelberg, pp 163-181

Pahnke A, Welter F (2019b) The German Mittelstand: antithesis to Silicon Valley entrepreneurship? GLO Research for Policy Note No 2 - Theme 3 Future of work Retrieved from https://glabor.org/ june-29-2019-friederike-welter-andre-pahnke-on-the-german-mittelstand-an-antithesis-to-siliconvalley-entrepreneurship-glo-research-for-policy-note-no-2/ (accessed 03/04/2020)

Pahnke A, Welter F (2019a) The German Mittelstand: antithesis to Silicon valley entrepreneurship? Small Bus Econ 52(2):345-358

Palii N, Oksenyuk V (2013) Hidden Champions of Ukraine. Hidden Champions in CEE and Turkey: Carving Out a Global Niche. Springer, Berlin, Heidelberg, pp 407-427

Pautasso M (2013) Ten simple rules for writing a literature review. PLoS Comput Biol 9(7):e1003149

Paxton P, Moody J (2003) Structure and sentiment: Explaining emotional attachment to group. Soc Psychol Q 66:34-47

Petraite M, Dlugoborskyte V (2017) Hidden Champions from Small Catching-Up Country: Leveraging Entrepreneurial Orientation, Organizational Capabilities and Global Networks'. Global Opportunities for Entrepreneurial Growth: Coopetition and Knowledge Dynamics within and across Firms. Emerald Publishing Limited, UK, pp 91-122

Pittrof M (2011) Die Bedeutung der Unternehmenskultur als Erfolgsfaktor für Hidden Champions. Gabler, Wiesbaden

Porter ME (1980) Competitive strategy: Techniques for analyzing industries and competitors. Free Press, New York, US

Purg D, Saginova O, Skorobogatykh I, Musatova Z (2016) Family owned Hidden champions in Russia: innovations, human capital and internationalization. Indian J Sci Technol 9(12):1-10

Quan XI, Qi S (2020) PhiChem: an entrepreneurship case study of a hidden champion in China. IEEE Eng Manag Rev 48(4):92-101

Rammer C, Spielkamp A (2015) Hidden champions-driven by innovation: empirische Befunde auf Basis des Mannheimer Innovationspanels ZEW - Leibniz-Zentrum für Europäische Wirtschaftsforschung: Mannheim

Rammer C, Spielkamp A (2019a) The distinct features of hidden champions in Germany: A dynamic capabilities view ZEW Discussion Papers, No19-012, ZEW - Leibniz-Zentrum für Europäische Wirtschaftsforschung: Mannheim, Germany

Rammer C, Spielkamp A (2019b) German hidden champions: competitive strategies, knowledge management and innovation in globally leading niche players. Ekonomiaz, Revista Vasca De Economía 95(1):65-87

Ramsey JR, Abi Aad A, Jiang C, Barakat L, Drummond V (2016) Emergence of cultural intelligence and global mindset capital: a multilevel model. Multinatl Bus Rev 24(2):106-122

Randolph J (2009) A guide to writing the dissertation literature review. Pract Assess Res Eval 14(1):1-13

Rant MB (2013a) Research Methodology. Hidden Champions in CEE and Turkey: Carving Out a Global Niche. Springer, Berlin, Heidelberg, pp 1-7

Rant MB (2013b) Hidden Champions of Slovenia. Hidden Champions in CEE and Turkey: Carving Out a Global Niche. Springer, Berlin, Heidelberg, pp 357-381

Rant MB, Černe SK (2017a) Becoming a hidden champion: from selective use of customer intimacy and product leadership to business attractiveness. South East Eur J Econom Business 12(1):89-103

Rant MB, Černe SK (2017b) How to successfully internationalize SMEs from the CEE region: the role of strategies of differentiation and education. J Manag Business Administration Central Europe 25(4):2-27 
Rasche C (2003) Was zeichnet die "Hidden Champions" aus Erfolgreich im Schatten der Großen. Kolleg für Leadership und Management, Berlin, pp 217-237

Reinemann H (2019) Mittelstand in der Betriebswirtschaftslehre - Theorien und Modelle. Mittelstandsmanagement. Springer Gabler, Wiesbaden, pp 23-61

Riisalu R, Leppiman A (2013) Hidden Champions of Estonia. Hidden Champions in CEE and Turkey: Carving Out a Global Niche. Springer, Berlin, Heidelberg, pp 183-199

Roberts J (2007) The modern firm: Organizational design for performance and growth. Oxford University Press, Oxford, UK

Rogoff EG, Heck RKZ (2003) Evolving research in entrepreneurship and family business: Recognizing family as the oxygen that feeds the fire of entrepreneurship. J Bus Ventur 18(5):559-566

Rosinus A (2016) Wofür steht eigentlich das „Mittel?” in Mittelstand? University of Applied Sciences, Fachbereich Wirtschaft School of Business, Hochschule Mainz

Ross S (1973) The economic theory of agency: the principal's problem. American Econ Rev 63:134-139

Rousseau DM (1998) Why workers still identify with organizations. J Organ Behav 19:217-233

Rusu B (2013) Hidden Champions from Romania. Hidden Champions in CEE and Turkey. Springer, Berlin, Heidelberg, pp 261-278

Saginova O, Skorobogatykh II, Musatova ZB (2014) Hidden champions in Russia: using western research methodology to study dynamically developing markets. Life Sci J 11(5):512-518

Saginova O, Musatova ZB, Skorobogatykh II (2019) Hidden Champions in Russia: Surviving and Developing 2011-2019. Small Firm Int Entrep

Santa M, Kekenovski L (2013) Hidden Champions of the Republic of Macedonia. Hidden Champions in CEE and Turkey: Carving Out a Global Niche. Springer, Berlin, Heidelberg, pp 245-260

Sauka A (2013) Hidden Champions of Latvia. Hidden Champions in CEE and Turkey: Carving Out a Global Niche. Springer, Berlin, Heidelberg, pp 219-244

Schenkenhofer J, Wilhelm D (2020) Fuelling Germany's Mittelstand with complementary human capital: the case of the Cooperative State University Baden-Württemberg. Eur J High Educ 10(1):72-92

Schlepphorst S, Schlömer-Laufen, N, Holz, M (2016) Determinants of hidden champions: Evidence from Germany Working Paper 03(16). Institut für Mittelstandsforschung (IfM): Bonn

Schulze WS, Lubatkin MH, Dino RN, Buchholtz AK (2001) Agency relationships in family firms: theory and evidence. Organ Sci 12:99-116

Schulze WS, Lubatkin MH, Dino RN (2002) Altruism, agency, and the competitiveness of family firms. Manag Decis Econ 23(4-5):247-259

Schulze WS, Lubatkin MH, Dino RN (2003) Toward a theory of agency and altruism in family firms. J Bus Ventur 18:473-490

Sharma P, Chrisman JJ, Chua JH (1997) Strategic management of the family business: past research and future challenges. Fam Bus Rev 10(1):1-35

Shepherd W G (1979) The Economics of Industrial Organization Prentice Hall: Englewood Cliffs, N J

Shleifer A, Vishny RW (1997) A survey of corporate governance. J Finance 52(2):737-783

Simon H (1990) Hidden Champions: Speerspitze der deutschen Wirtschaft. Johannes-Gutenberg-University, Mainz, Germany, Chair for Business and Marketing

Simon H (1992) Lessons from Germany's midsize giants. Harvard Bus Rev 70(2):115-123

Simon H (1996a) You don't have to be German to be a "hidden champion.” Bus Strateg Rev 7(2):1-13

Simon H (1996b) Hidden champions: Lessons from 500 of the world's best unknown companies. Harvard Business School Press, Boston, MA

Simon H (2007) Hidden Champions des 21. Die Erfolgsstrategien unbekannter Weltmarktführer. Campus Verlag, Frankfurt, Jahrhunderts

Simon H (2009) Hidden Champions of the 21st Century: Success Strategies of Unknown Market-Leaders. Springer, Heidelberg

Simon H (2012) Hidden Champions-Aufbruch nach Globalia: Die Erfolgsstrategien unbekannter Weltmarktführer. Campus Verlag, Frankfurt

Simon H (2018) Wie Marketing von den Hidden Champions lernen kann. In: Bruhn M, Kirchgeorg M (eds) Marketing Weiterdenken. Springer Gabler, Wiesbaden, pp 201-212

Simon H (2020) Erfolgsfaktoren von Hidden Champions bei der Digitalisierung. In: Bruhn M, Kirchgeorg M (eds) Marketing Weiterdenken. Springer Gabler, Wiesbaden, pp 151-161

Simon H, Lippert S (2007) Hidden Champions des 21. Jahrhunderts Deutschland Und Japan Im Vergleich Japanmarkt 4(1):8-15

Simon H, Zatta D (2008) Growth Strategies from the Hidden Champions. In: Da-Cruz P, Cappallo S (eds). Gesundheitsmegamarkt Indien, Gabler 
Simon H (2021) Hidden Champions. The new rules of the game in the Chinese century. Campus, Frankfurt

Skorobogatykh II, Saginova OV, Musatova ZB (2013) Hidden Champions of Russia. Hidden Champions in CEE and Turkey. Springer, Berlin, Heidelberg, pp 279-305

Smidts A, Pruyn ATH, Van Riel CB (2001) The impact of employee communication and perceived external prestige on organizational identification. Academy Manag J 44(5):1051-1062

Sommariva A, Tullio G (1987) German Macroeconomic History 1880-1979 McMillan: London, UK

Sperber J (1997) Bürger, Bürgertum, Bürgerlichkeit, Bürgerliche Gesellschaft: studies of the German (Upper) middle class and its sociocultural world. J Modern Hist 69(2):271-297

Stocker M, Szlávik P (2013) Hidden Champions of Hungary. Hidden Champions in CEE and Turkey: Carving Out a Global Niche. Springer, Berlin, Heidelberg, pp 201-217

Suh Y, Kim MS (2014) Internationally leading SMEs vs internationalized SMEs: Evidence of success factors from South Korea. Int Bus Rev 23(1):115-129

Sutherland I, Purg D (2013) Leadership of Hidden Champions: From Vision to Communityship. Hidden Champions in CEE and Turkey. Springer, Berlin, Heidelberg, pp 19-36

Swartz S (1989) The challenges of multidisciplinary consulting to family-owned businesses. Fam Bus Rev 2(4):329-331

Táborecká-Petrovičová J, Ďado J, Bobáková T (2013) Hidden Champions of Slovakia. Hidden Champions in CEE and Turkey: Carving Out a Global Niche. Springer, Berlin, Heidelberg, pp 331-355

Thomson M, MacInnis DJ, Whan Park C (2005) The ties that bind: measuring the strength of consumers' emotional attachments to brands. J Consumer Psychol 15(1):77-91

Tiwari R, Buse S (2014) German Mittelstand discovers BRIC: a survey of product strategies of German 'Hidden Champions' in China and India. Indo-German Econ 5(1):5-11

Toften K, Hammervoll T (2010) Strategic orientation of niche firms. J Res in Marketing Entrepr 28(6):736-753

Torp C (2010) The coalition of 'rye and iron' under the pressure of globalization: a reinterpretation of Germany's political economy before 1914. Central Eur Hist 43(3):401-427

Torraco RJ (2005) Writing integrative literature reviews: guidelines and examples. Hum Resour Dev Rev 4(3):356-367

Trott P (2012) Innovation Management and New Product Development. 5th edn. Financial Times Prentice Hall, Edinburgh Gate, Harlow

Van Knippenberg D (2000) Work motivation and performance: a social identity perspective. Appl Psychol Int Rev 49:357-371

Veblen T (1990) Imperial Germany and the industrial revolution. Seeker and Warburg, London, UK

Venohr B, Kamp B (2019) Global niche market leaders in emerging Asia and the necessity to become market insiders. Ekon Rev Vasca Econ 95(01):111-133

Venohr B, Meyer K (2009) Uncommon common sense: success strategies for mid-size firms. Bus Strateg Rev 20(1):38-43

Venohr B, Fear J, Witt A (2015) Best of German Mittelstand-the world market leaders DAAB MEDIA. Cologne, Germany

Venohr B, Bruche G (2015) German Mittelstand Champions in Asia-Catching the Next Wave of Growth Available at SSRN: https://papers.ssrn.com/sol3/papers.cfm?abstract_id=2725336 or

Venohr B, Meyer K (2007) The German Miracle Keeps Running: How Germany's Hidden Champions Stay Ahead in the Global Economy Berlin. Working Paper No 30 Institute of Management Berlin, Berlin School of Economics

Villalonga B, Amit R (2006) How do family ownership, management, and control affect firm value? J Financ Econ 80(2):385-417

Vitols S (2001) The origins of bank based and market based financial systems: Germany, Japan, and the United States. The origins of nonliberal capitalism: Germany and Japan in comparison. Cornell University Press, Ithaca, London, pp 171-199

Vonnahme L, Lang T (2021) Hidden champions in rural Germany: Innovation strategies to compete in global markets. In: Leick B, Gretzinger S, Makkonen T (eds) The Rural Enterprise Economy. Routledge, London, pp 35-52

Vonnahme L, Graffenberger M, Görmar F, Lang T (2018) Kaum beachtet, gemeinsam stark: versteckte Potenziale von Kleinstädten mit Hidden Champions. Informationen Zur Raumentwicklung 6:38-49 
Vonnahme L, Lang T (2019) Peripher global: Ergebnisse der standardisierten Befragung zu Innovationsaktivitäten von Weltmarktführern in Deutschland. Working Paper 18 SFB 1199, University of Leipzig, Leipzig, Germany

Voudouris I, Lioukas S, Makridakis S, Spanos Y (2000) Greek hidden champions: lessons from small, little-known firms in Greece. Eur Manag J 18(6):663-674

Wagner D, Block JH, Miller D, Schwens C, Xi G (2015) A meta-analysis of the financial performance of family firms: another attempt. J Fam Bus Strateg 6(1):3-13

Walravens A, Filipović N (2013) Three Bivalent Performance Factors of Hidden Champions: Ownership, Organizational Culture and Organizational Governance. Hidden Champions in CEE and Turkey: Carving Out a Global Niche. Springer, Berlin, Heidelberg, pp 37-52

Weber M (1930) The Protestant Ethic and the Spirit of Capitalism: Translated from the German. Scribner's, New York, NY

Webster J, Watson R T (2002) Analyzing the past to prepare for the future: Writing a literature review. MIS Q 26 (2): xiii-xxiii

Weisbrod B (1996) German unification and the national paradigm. German Hist 14(2):193-203

Welter F (2011) Contextualizing entrepreneurship—conceptual challenges and ways forward. Entrepr Theory Pract 35(1):165-184

Welter F (2018) The Mittelstand: a specific entrepreneurial profile of the social market economy. J Mark Ethics 6(1):99-106

Welter F, Gartner WB (2016) A research agenda for entrepreneurship and context. Edward Elgar Publishing, Cheltenham

Welter F, Baker T, Audretsch DB, Gartner WB (2017) Everyday entrepreneurship: a call for entrepreneurship research to embrace entrepreneurial diversity. Entrepr Theory Pract 41(3):311-321

Welter F, May-Strobl E, Schlömer-Laufen N, Kranzusch P, Ettl K (2014a) Das Zukunftspanel Mittelstand: Eine Expertenbefragung zu den Herausforderungen des Mittelstands (No 229) IfMMaterialien, Institut für Mittelstandsforschung (IfM) Bonn

Welter F, May-Strobl E, Wolter H J, Günterberg B (2014b) Mittelstand im Wandel (No 232) IfMMaterialien. Institut für Mittelstandsforschung (IfM) Bonn

Welter F, May-Strobl E, Holz M, Pahnke, A, Schlepphorst S, Wolter H J, Kranzusch, P (2015) Mittelstand zwischen Fakten und Gefühl (No 234) IfM-Materialien, Institut für Mittelstandsforschung (IfM) Bonn

Whiteside MF, Brown FH (1991) Drawbacks of a dual systems approach to family firms: can we expand our thinking? Fam Bus Rev 4(4):383-395

Williamson O E (1975) Markets and Hierarchies, Analysis and Antitrust Implications. Simon \& Schuster, New York, US

Witt A (2010) Internationalisation Strategies of Hidden Champions. Management Laboratory Press, Hamburg

Witt A, Carr C (2013) A critical review of Hidden Champions and emerging research findings on their international strategies and orientations. In: Cook G, Johns J (eds) The Changing Geography of International Business. Palgrave MacMillan, Houndmills, Basingstoke, UK, pp 95-113

Witt A (2015) Global Hidden Champions: The Internationalisation Paths, Entry Modes and Underlying Competitive Advantages of Germany's and Britain's Global 'top three' Niche Players. University of Edinburgh, Scotland, UK

Wittenstein D (2020) Champions of Digital Transformation? The Dynamic Capabilities of Hidden Champions. ZEW-Centre for European Economic Research Discussion Paper No. 20-065

Yoon B (2011) Success Factors for Innovation of Global Leading SMEs in Manufacturing Industries September 20-23. Istanbul Bilgi University, Turkey

Yoon B (2012) Analysis of Success Factors for Innovation of Global Leading SMEs. J Korea Technol Innovation Soc 15(1):76-104

Yoon B (2013) How do hidden champions differ from normal small and medium enterprises (SMEs) in innovation activities? J Appl Sci Res 9(13):6257-6263

Yosun T, Çetindamar D (2013a) Hidden champions of Turkey. Hidden Champions in CEE and Turkey. Springer, Berlin, Heidelberg, pp 383-405

Yosun T, Çetindamar D (2013b) How do emerging market firms become "Champions" in global markets? Evidence from Turkey. In: academy of international business annual meeting (AIB 2013), Istanbul, Turkey

Zahra SA (2003) International expansion of US manufacturing family businesses: the effect of ownership and involvement. J Bus Ventur 18(4):495-512 
Zahra SA (2005) Entrepreneurial risk taking in family firms. Fam Bus Rev 18(1):23-40

Zahra SA, Hayton JC, Salvato C (2004) Entrepreneurship in family vs non-family firms: a resourcebased analysis of the effect of organizational culture. Entrepr Theory Pract 28(4):363-381

Zastempowski M (2011) The innovative potential of the hidden champions of the polish economy. Contemp Manag Q 4(1):52-58

Zellweger TM, Astrachan JH (2008) On the emotional value of owning a firm. Fam Bus Rev 21(4):347-363

Zellweger TM, Eddleston KA, Kellermanns FW (2010) Exploring the concept of familiness: introducing family firm identity. J Fam Bus Strat 1(1):54-63

Zellweger TM, Nason RS, Nordqvist M, Brush CG (2011) Why do family firms strive for nonfinancial goals? An organizational identity perspective. Entrepr Theory Pract 37(2):229-248

Zhexembayeva N (2013) In Search of Sustainable Business in Central and Eastern Europe. Hidden Champions in CEE and Turkey: Carving Out a Global Niche. Springer, Berlin, Heidelberg, pp 81-93

Publisher's Note Springer Nature remains neutral with regard to jurisdictional claims in published maps and institutional affiliations. 